\title{
Census Bulletin.
}

No. 228.

WASHINGTON, D. C.

July 3, 1902.

\section{MANUFAC'TURES. \\ GLASS MANUFACTURE.}

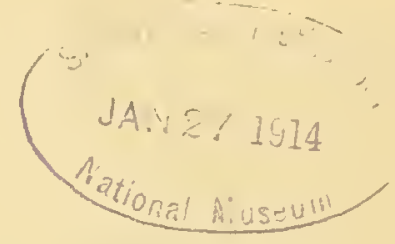

Hon. Williay R. MerRiam, Director of the Census.

SIR: I transmit helewith, for publication in bulletin form, a report on glass manufacture, prepared uncler my direction by Mr. Shirley P. Austin, of Pittsburg, $\mathrm{Pa}$, acting in the capacity of an expert special agent of the division of mannfactures of the Census Office.

The statistics of glass manufacture were reported in 1880 and 1890 under four subdivisions, that is: Plate glass, window glass, glassware, and green and black glass. A separate schedule was prepared for each subdirision. In 1900 it was decided to assign the reports for the indnstry to two classes of products: Building glass, including plate glass, all varieties of cast and rolled sheet glass, and window glass; and pressed and blown ware and bottles and jars, including all pressed or blown flint glassware, and bottles and jars of flint, green, or amber glass.

The statistics seem to show a satisfactory rate of growth in the several hranches of the industry, notwithstanding the fact that in nearly all lines the domestic mannfactnrers have been compelled to meet a vigorous foreign competition. The development of the industry has been marked by a noteworthy increase in the use of tank furnaces, and mechanical processes in lieu of hand work, which have resulted in an increased output combined with greater economy of operation. 'The distribution of the factories has depended to a considerable extent npon the supply of natural gas, the discovery of new fields being marked by an influx of glass factories from other localities having less favorable advantages in respect to fuel.
The statistics are presented in 14 tables: Table 1 , comparative figures for the industry at the several censuses; Table 2, the statistics for idle establishments; Table 3, value of new construction; Tables 4 and 5, comparative statistics, by states, and by classes of products, respectively, 1880 to 1900 ; Table 6 , rank of states according to value of products, with per cent of total value, 1880 to 1900 ; Tables $T$ and $\&$, comparative statistics of the manufacture of building glass and the manufacture of pressed and blown glass and bottles and jars, respectively, by states, 1890 and 1900; Table 9, number of bottles manufactured, classified by capacity, by states; Table 10, imports and exports of glass; Table 11, comparative summary of materials nsed, 1590 and 1900; Tables 12, 13, and 1t, presenting detailed statistics of the combined indnstry, the manufacture of building glass, and the manufacture of pressed and blown glass and botties and jars, respec tively.

In drafting the schedules of inquiry for the census of 1900 , care was taken to preserve the basis of comparison with prior censuses. Comparison may be made safely with respect to all the general heads of the inquire cxcept those relating to capital, salaried officials, clerks, ctc., and their salaries, the arerage number of employees, and the total amonnt of wages paid. Live capital, that is, cash on hand, bills receirable, unsettled ledger accounts, raw materials, stock in process of manufacture, finished products on hand, and other sundries. was first called for at the census of 1890. To definite attempt was made. prior to the census of 1890 , to secure a retur'n of live capital invested. 
Changes were made in the inquiries relating to emplorees and wages. in order" to elminate defects found to exist on the form of inquiry aldopted in 1890 . At the census of 1890 the arerage number of persons enployed during the entire rear wis called for. and also the arerage number employed at stated weekly rates of paly. and the arerage number was computed for the actual time the establishments were reported as heing in operation. At the census of 1900 the greatest and leist number of employees were reported, and also the arerige number enployed during each month of the rear. The arerage number of wage-earner's (men, women, and children) employed during the entire year was ascertained by using 12 , the number of calendar months, as a dirisor into the total of the arerage numhers reported for each month. This difference in the method of ascertaining the arelage number of wageearners during the entire rear may have resulted in a variation in the number, and should be considered in making comparisons.

At the census of 1590 the number and salaries of proprietors and firm members actirely engaged in the business or in superrision were reported, combined with clerks and other officials. In cases where proprietors and firm member's were reported without salaries, the amount that would ordinarily be paid for similar services was estimated. At the census of 1900 only the number of proprietors and firm nembers actively engaged in the industry or in superrision was ascertained, and no salaries were reported for this class. It is therefore impossible to compare the number and salaries of salaried officials of any character for the two censuses.

Furthermore, the schedules for 1590 included in the wage-earning class overseers, foremen, and superintendents (not general superintendents or managers), while the census of 1900 separates from the wageearning class such salaried employees as general superintendents, clerks, and salesmen. It is possible and probable that this change in the form of the question hats resulted in eliminating from the wage-earners, as reported by the present census, many high-saliaried employees included in that group for the census of 1890 . With the exception of several other changes in the special features of the sehedule, the inrestigation has been conducted along the lines followed at the census of 1890 .

In some instances the number of proprietors and firm members. shown in the accompanying tables. falls short of the number of establishments reported. This is accounted for by the filct that no proprietors or firm members are reported for corporations. The reports show a capital of $\$ 61.423 .908$ invested in the 355 establishments reporting for the industry. This sum represents the value of land, buildings, machincry, tools, and implements, and the lire capital utilized, but does not include the capital stock of any of the corporations. The value of the products is returned at $\$ 56,539,712$; to produce which involved an outlay of $\$ 2,792,376$ for salaries of officials, clerks, ete; $\$ 27,0 \$ 4,710$ for wages: $\$ 3.588,641$ for miscellancous expenses, including rent, taxes, etc.; and \$16,731.009 for materials used, mill supplies, freight, and fuel. It is not to be assumed, however, that the difference between the aggregate of these sums and the value of the products, is, in any sense, indicative of the profits in the manufacture of the products during the census year. The census schedule takes no cognizance of the cost of selling manufaetured articles. or of interest on capital invested, or of the mercantile losses incurred in the business, or of depreciation in plant. The value of the product given is the value as obtained or fixed at the factory. This statement is necessary in order to aroid erroneous conchusions from the figures presented. Very respectfully,

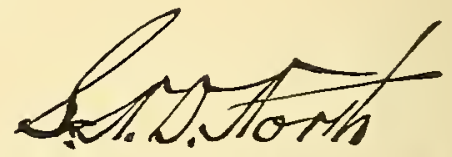

Chief Statistician for Manufactures 


\title{
GLASS MANUFACTURE//
}

\author{
Bỵ Shrrler P. Austix, Expert Special Agent.
}

The manufacture of glass in this country dates almost from the arrival of the first English colonists in what is now the United States. One of the earliest attcmpts, if not the first, at manufacturing in the original thirteen colonies was directed toward the production of glass, and a glass works erected for that purpose in 1608 or 1609 , and located about a mile from Jamcstown, Va., was probably the first manufactory erected in America by the English colonists. In 1608 the London Company sent glassworkers to America to opcrate the plant, and in the following year some of the products constituted a part of the first cargo of goods exported from this country. ${ }^{1}$ This first glass factory probably produced bottles exclusively. Its career was brief, as in 1617 it was reported fallen into decay, and later was swept entirely away in the Indian massacre of 1622 . In 1620 a subscription list was started in Jamestown to erect a factory for the manufacture of glass beads, the currency among the Indians, and in 1621 the London Company sent Italian workmen for this plant, which seems to hare been located some distance from Jamestown, as it escaped the massacre of 1622 , and is referred to as late as 1623 . In 1639 a glass factory was located at Salem, Mass., and previous to this, although the exact date is not known, glass was first made in New York on Manhattan Island. ${ }^{2}$ The first mention of a glass factory in Pennsylvania is contained in a very vague reference in a letter written by William Penn in 1683. The progress of the industry during the colonial period was slow and financial reverses were the rule. The scarcity of glass during the Revolutionary War stimulated factory erection, and early in the Nineteenth century the industry assumed much prominence, being confined largely to Massachusetts, New York, eastern Pennscrlrania, New Jersey, and Maryland. These early factories were usually situated within easy access to forests, from which

\footnotetext{
'Stith's History of Virginia, pages 77 and 82.

${ }^{2}$ Bishop's History of American Manufactures, Vol. I, pages 233 and 234 .
}

the fuel supply was obtained. Not until the erection of the first factory west of the Allegheny Mountains, at Pittsburg in 1797, was coal used as a fuel in glass manufacture, and it was many years before it came into general use. ${ }^{3} \quad$ The Atlantic seaboard long held supremacy in the manufacture of glass, but with the westward spread of population and the discovery of rich fuel resources in western Pennsylvania, West Virginia, Ohio, and Indiana, the center of the industry has steadily mored westward and the bulk of the production has been for some time west of the Alleghenies.

This report, with the statistical tables accompanying it, includes only establishments manufacturing glass from the crude material and does not include the large number of separate establishments engaged in the reworking of glass, such as silvering, bereling, cutting, engraving, decorating, etc. A number of the glass establishments, however, carry on these processes in direct connection with the manufacture of the "metal" in the same factory, and such establishments are included.

The inquiry into glass manufacture for this census was based on the following classification of the industry: (1) Building glass, all establishments making common window glass, plate glass, and all rarieties of cast and rolled sheet glass; (2) pressed and blown glass, all establishments manufacturing pressed or blown flint. glassware, tableware, jellies, tumbler's, goblets, lamps, chinneys, lantern globcs, gas and electric lighting ware, stem ware, opal ware. cut glass, etc.: (3) bottles and jars, all establishments manufacturing bottles and jar's in flint, green, or amber glass. It has been found necessary to combine the last two divisions, as several firms reported production in both these branches.

Table 1 is a comparative summary of the statistics for the industry as returned at the censuses of 1850 to 1900 , inclusive, with the percentages of increase for each decade. 277.

${ }^{3}$ History of Pittsburg, by Nerille B. Craig, 1851, pages 276 and 
TABLE 1.-COMPARATIVE SUMMART, 1850 TO 1900, WITH PER CENT OF INCREASE FOR EACH DECADE.

\begin{tabular}{|c|c|c|c|c|c|c|c|c|c|c|c|}
\hline & \multicolumn{6}{|c|}{ DATE OF CESEUS, } & \multicolumn{5}{|c|}{ PER CENT OF 1NCREASE. } \\
\hline & 1900 & 1890 & $15-0$ & 1870 & 1560 & 1850 & $\begin{array}{c}1800 \\
\text { to } \\
1900\end{array}$ & $\begin{array}{c}1880 \\
\text { to } \\
1590\end{array}$ & $\begin{array}{c}1 \leqslant 70 \\
t 0 \\
1 \leqslant 0\end{array}$ & $\begin{array}{c}1860 \\
10 \\
1570\end{array}$ & $\begin{array}{c}1850 \\
\text { to } \\
1660\end{array}$ \\
\hline 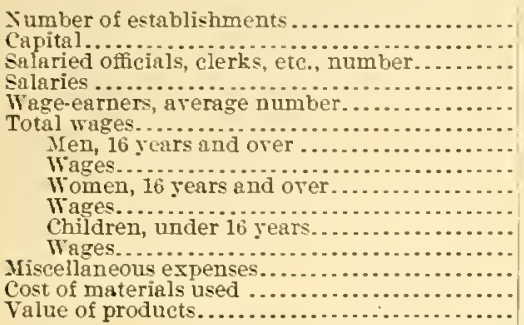 & $\begin{array}{r}355 \\
861,423,903 \\
2,268 \\
\leqslant 2,792,376 \\
52,818 \\
s 27,084,710 \\
42,173 \\
s 24,901,233 \\
3,529 \\
8840,001 \\
7,116 \\
\$ 1,343,476 \\
53,585,641 \\
\$ 16,731,009 \\
\$ 56,539,712\end{array}$ & $\begin{array}{r}\$ 10,966,850 \\
21,095 \\
2 \$ 1,232,561 \\
44,892 \\
\leqslant 20,855,961 \\
36,064 \\
\$ 19,516,351 \\
1,855 \\
\$ 332,245 \\
6,943 \\
\$ 1,007,365 \\
\$ 2,267,696 \\
\$ 12,140,985 \\
\$ 41,051,004\end{array}$ & 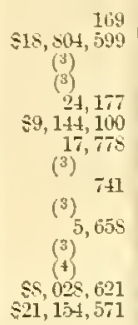 & 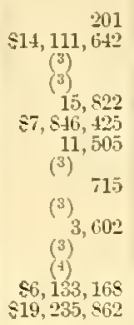 & 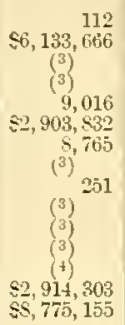 & $\begin{array}{c}94 \\
\$ 3,402,350 \\
(3) \\
(3) \\
5,668 \\
\$ 2,094,576 \\
5,571 \\
\left({ }^{3}\right) \\
(87 \\
(3) \\
(3) \\
(4) \\
\$ 1,556,833 \\
\$ 1,641,676\end{array}$ & $\begin{array}{r}20.7 \\
49.9 \\
107.1 \\
126.6 \\
17.7 \\
29.7 \\
16.9 \\
27.4 \\
87.2 \\
152.8 \\
2.5 \\
33.4 \\
54.3 \\
37.8 \\
37.7\end{array}$ & \begin{tabular}{r}
74.0 \\
117.9 \\
$\cdots \ldots .$. \\
\hdashline 85.7 \\
128.4 \\
102.9 \\
\hdashline 19.9 \\
154.4 \\
22.7 \\
$\ldots \ldots .$. \\
\hdashline 51.2 \\
94.1
\end{tabular} & \begin{tabular}{r}
1 \\
15.9 \\
33.3 \\
$\ldots \ldots .$. \\
\hdashline 52.8 \\
16.5 \\
54.5 \\
$\ldots 3.6$ \\
$\ldots .6$ \\
57.1 \\
$\ldots \ldots .$. \\
\hdashline 30.9 \\
10.0
\end{tabular} & $\begin{array}{r}79.5 \\
130.1 \\
\ldots \ldots . . \\
75.5 \\
170.2 \\
31.3\end{array}$ & 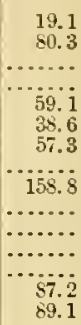 \\
\hline
\end{tabular}

1 Decrease. 2Includes proprietors and firm members, with their salaries; number only reported in 1900, but not included in this table. (See Table 12.)

s Yot reported separately.

The remarkable growth of the glass making industry in the last half century is shown in Table 1 . With the exception of a decrease in the number of cstablishments between 1870 and 1880 , the table shows a steady increase in ereiy item from 1850 to 1900 . From 1850 to 1900 the number of establishments increased 261, or 27 .7 per cent. The great improvement in factory construction and equipment and the broadening of the scope of the business during the same period are indicated by the increase in capital from $\$ 3,402,350$ in 1850 to $\$ 61,+23,903$ in 1900 , or $1,705.3$ per cent. The number of wage-earners has increased from 5,668 in 1850 to 52,818 in 1900 , or 831.9 per cent; and wages paid, from $\$ 2,094,576$ in 1850 to $\$ 27,084,710$ in 1900 , or $1,193.1$ per cent. During the same period the cost of materials used has increased from $\$ 1,556,838$ to $\$ 16,781,009$, or 974.7 per cent; and the value of products, from $\$ 4,641,676$ to $\$ 56,539,712$, or $1,118.1$ per cent.

The growth from 1890 to 1900 was vigorous, as shown by an increase of 20.7 per cent in number of active establishments, and of 49.9 per cent in capital invested. The increase in capital was largely caused by the general introduction during the decade of the tank melting furnace, which necessitates much more costly and permanent factory construction and equipment than the pot furnace, which it is fast supplanting.

Of the total cost of materials used in $1900, \$ 16,731,009$, the principal item was the cost of packages and package materials, which was $\$ 3,390,627$, and in 1890 was $\$ 1,853,462$, an increase of $\$ 1,53 \pi, 165$, or $\$ 2.9$ per cent. This large increase was caused in part by the demand for a neater package for finished products in nearly all lines of glass manufacture, created by increased competition, and by the more general use of the carton package for lamp chimneys. shades, globes, and the great variety of high-grade glassware, and the increased use of paper between sheets in packing building glass. In addition to the above package materials, establishments manufacturing pressed and blown ware, bottles, and jars reported in $1900, \$ 1,522.916$ as the cost of caps. metal trimmings, and rubber supplies. The cost of these materials was not reported separately at the census of 1890 , but there has been an cnormous increase in their consumption.

The total cost of fuel in 1900 was reported as $\$ 3,203,146$. Of this amount, natural gas cost $\$ 1.575,278$; coal, $\$ 1,074,07 t$; and oil, $\$ 409,158$; the remainder being divided between coke and wood. A number of establishments, particularly in Indiana, reported little or no cost for fuel, as they were either getting "free gas" as an inducement for location, or owned the source of their supply, and reported the small cost of maintenance under the item of general expense. Hence there was a large amount of natural gas used as fuel which was not reported.

Soda ash is the third largest item of cost in materials used, 157,779 tons being reported, at a cost of $\$ 2,259,939$. In $1890,96,777$ tons were reported, costing $\$ 3,108,233$. The average cost per ton in 1900 was $\$ 14.32$, and in $1890, \$ 32.12$. While the quantity of soda ash used in glass manufacture during the decade increased 63 per cent, the cost decreased 27.3 per cent. The comparison shows the benefits derived by the glass industry from the development of the American sodaash manufacture in the last ten years, a development that received the greater share of its impetus from men actirely connected with the glass industry.

The increase in the value of products between 1890 and 1900 was 37.7 per cent, but it is safe to say the increase in the quantity of products was in excess of that, especially in the output of bottles, jars, and glassware, owing to the general introduction of the tank melting furnace and the adoption of improved mechanical equipment. The number of pieces of glassware, bottles, jars, etc., manufactured, was not reported at the census of 1890. It is therefore impossible to make a comparison with such data at the present census. The total production of plate glass, rough and polished, in 1890, was $12,206,942$ square feet; and in $1900,17,512,262$ square feet, an increase of 43.5 per cent. There were $2,773.82 \pm$ square feet of eathedral glass manufactured in 1890 , and $8.8 \pm 6.361$ square feet in 1900 , or an 
increase of 218.9 per cent. The quantities of skylight and wire glass manufactured in 1900 were $3,679,694$, and $1,295,504$ square feet, respectively. No report was made of these products at the census of 1890 . In 1890 there were $3,768,38 \pm$ boxes of window glass manufactured, and $4,3+1,282$ boxes in 1900 , an increase of only 15.2 per cent. The comparatively small increase is explained by the much shorter " run" of factories during the "fire" corered by the present census, the average "run" being about six months in 1990 and nearly ten months in 1890 . In addition, a large percentage of the available capacity of the factories was idle in 1900 for want of workmen.

Table 2 shows the idle establishments, by states, with the capital invested and the equipment of the factories, for 1900 .

TABLE 2.-IDLE ESTABLISHMENTS, BY STATES: 1900.

\begin{tabular}{|c|c|c|c|c|c|c|c|c|c|c|}
\hline & $\begin{array}{l}\text { United } \\
\text { States. }\end{array}$ & Illinois. & Indiana. & Kentucky. & $\begin{array}{c}\text { New } \\
\text { Jersey. }\end{array}$ & New York. & Obio. & $\begin{array}{c}\text { Pennsyl- } \\
\text { vania. }\end{array}$ & $\begin{array}{c}\text { Washing- } \\
\text { ton. }\end{array}$ & $\begin{array}{l}\text { West } \\
\text { Virginia. }\end{array}$ \\
\hline 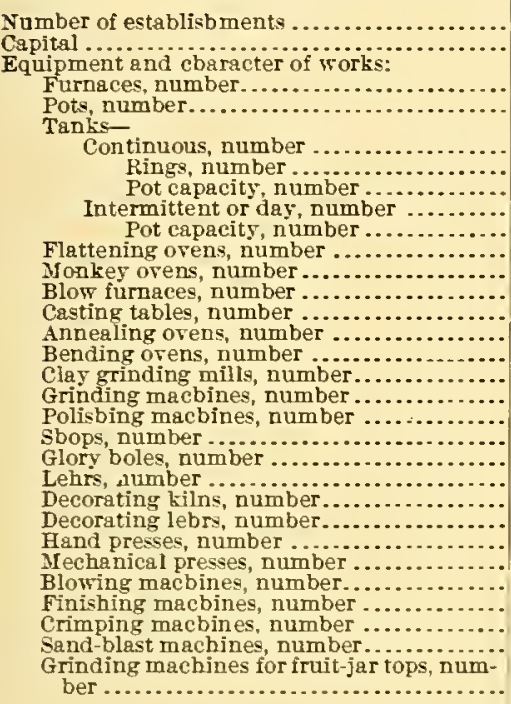 & $\begin{array}{r}41 \\
485 \\
27 \\
248 \\
592 \\
16 \\
139 \\
38 \\
32 \\
20 \\
6 \\
67 \\
3 \\
2 \\
13 \\
3 \\
167 \\
118 \\
153 \\
11 \\
2 \\
56 \\
12 \\
10 \\
15 \\
16 \\
3 \\
4 \\
4\end{array}$ & 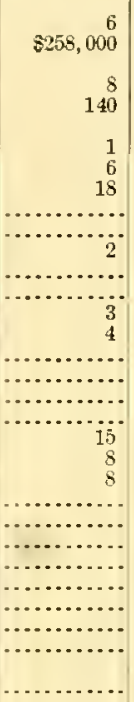 & 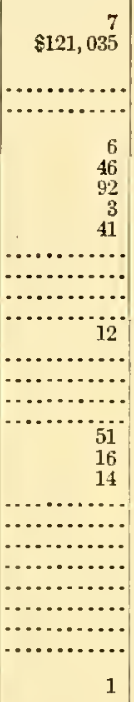 & 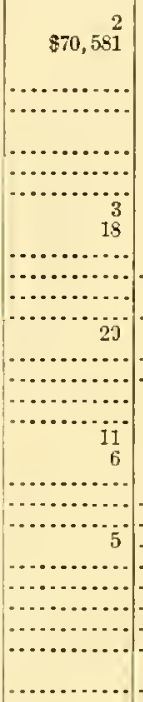 & $\begin{array}{r}8 \\
\$ 84,700 \\
6 \\
42 \\
3 \\
29 \\
82 \\
1 \\
36 \\
11 \\
\ldots \ldots . . .\end{array}$ & 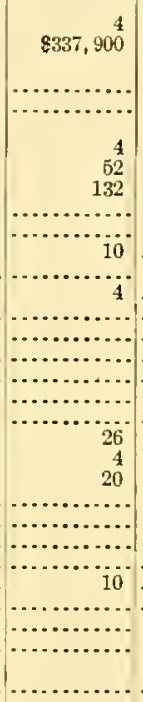 & $\begin{array}{r}8 \\
\$ 308,018 \\
\\
8 \\
87 \\
\\
2 \\
15 \\
30 \\
2 \\
4 \\
\ldots \ldots \\
30\end{array}$ & $\begin{array}{r}1,968,5.52 \\
13 \\
156 \\
\\
10 \\
90 \\
218 \\
4 \\
15 \\
14 \\
2 \\
12 \\
3 \\
16 \\
2 \\
2 \\
5 \\
1 \\
43 \\
55 \\
47 \\
1 \\
1 \\
29 \\
7\end{array}$ & 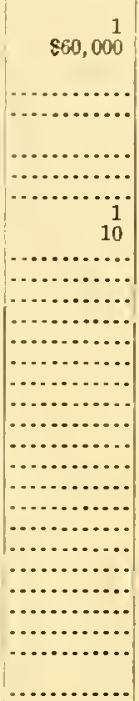 & 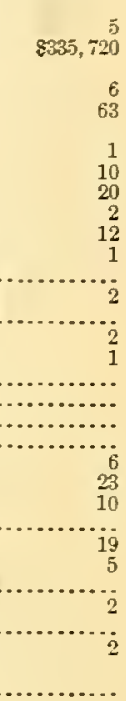 \\
\hline
\end{tabular}

In addition to the 3555 active establishments reported in 1900, Table 2 shows that 60 establishments, with a capital of $\$ 3,544,536$, were reported as idle during the census year. These establishments were located as follows, by states: Illinois, 6; Indiana, 7; Kentucky, 2; New Jersey, 8; New York, 4; Ohio, 8; Pennsylvania, 19; Washington, 1; West Virginia, 5. Only those idle establishments that seemed reasonably certain of being. again put in operation in the near future are included in Table 2. No account was taken of the many dismantled and abandoned glass factories in the country.

Of the 60 idle establishments reported, 41 , with a capital of $\$ 2,296,587$, were for the manufacture of pressed and blown ware or bottles and jars. The equipment of these establishments was as follows: 22 furnaces of 257 pots; 19 continuous tanks of 152 rings, or 304 pots capacity; 11 intermittent or day tanks of 120 pots capacity; 118 glory holes; 61 annealing orens; 117 lehrs: 11 decorating kilns; 2 decorating lehrs; 56 hand presses; 12 mechanical presses; 10 blowing machines; 15 finishing machines; 16 crimping machines; 3 sand-blast machines; and $t$ machines for grinding fruit jar tops. The remaining 19 idle establishments wcre building-glass factories, which reported a total capital of $\$ 1,247,949$, and the following equipment: 19 furnaces of 231 pots; 8 continuous tanks of 96 rings or 288 pots capacity; 5 day tanks of 19 pots capacity; 38 flattening ovens; 32 monkey ovens; 20 blow furnaces; 6 casting tables; 6 annealing orens; 3 bending orens; 36 lehrs; 13 grinding machines; 3 polishing machines; and 2 elay grinding mills.

In addition to the establishments that were idle throughout the census year, a certain portion of the furnace equipment of active establishments was reported as idle. In active building glass factories, 29 pot furnaces with 471 pots, and one intermittent or das tank furnace of 7 pots capacity were reported as idle. In active pressed and blown ware and bottle and jar factories, 31 pot furnaces with 336 pots, 14 continuous tank furnaces with 79 rings of 158 pots capacitr, and 16 intermittent or day tank furnaces of 66 pots capacity were reported as idle. The entire idle furnace equipment of active establishments in both branches of glass manufacture was as follows: 60 pot furnaces with sut pots, 14 continuous tank furnaces with 79 rings of 158 pots eapacity, and 16 intermittent or day tank furnaces of 83 pots capacity. It should be stated in this connection that this idle equipment is included in all tables presenting such data in this report, except Table 2 . Adding the statistics of actire establishments to those shown in Table 2 gives a total of 415 active and idle establishments in the United States, with a capital of 
$\$ 64,968,439$. The combined equipmcnt of all establishments is as follows: Furnaces, 492 ; pots, 5.595 ; continuous tanks, 233; pot capacity of continuous tanks, 4,525 ; intermittent or day tanks, 163; pot capacity of intermittent or day tanks, 1,040; flattening orens, 323; monkey orens, 34 ; blow furnaces, 279 ; casting tables, 106; annealing ovens, 936; bending orens, 12: clay grinding mills, 73; grinding machines, 240; polishing machines, 297; shops, 4,145; glory holes, 1,537; lehrs, 1,480; decorating kilns, 116; decorating lehrs, 25 ; hand presses, 971 ; mechanical presses, 61 ; blowing machines, 179; finishing machines, 155 ; crimping machines, 510; mechanical polishers, 16 ; sand-blast machines, 76 ; grinding machines for fruit jar tops, $1 \pm 1$.

Table 3 presents the valuc of new construction, by states, during the census ycar. Only the value of additions to existing factories is given in the table, not including ordinary repairs and the value of new plants constructed.
TIBLE 3.-NEIF CONSTRUCTION, BY STATES: 1900.

\begin{tabular}{|c|c|}
\hline STATES. & $\begin{array}{l}\text { Cost of new } \\
\text { construction } \\
\text { (additions to } \\
\text { old worls, } \\
\text { not includ- } \\
\text { ing ordinary } \\
\text { repairs) dur- } \\
\text { ing census } \\
\text { ycar. }\end{array}$ \\
\hline United states ....... & $\$ 578,917$ \\
\hline Georgia. . & 2,500 \\
\hline 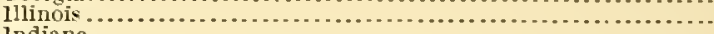 & 43,448 \\
\hline $\begin{array}{l}\text { Indiana } \\
\text { Mfichigan } . \ldots \ldots \ldots \ldots\end{array}$ & 186.004 \\
\hline $\begin{array}{l}\text { Nichigan } \\
\text { New Jersey }\end{array}$ & $\begin{array}{r}4,848 \\
22,664\end{array}$ \\
\hline 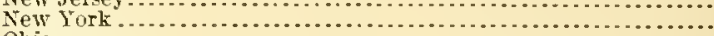 & 37,429 \\
\hline $\begin{array}{l}\text { Ohio } \\
\text { Pennsvivania }\end{array}$ & $26,1 \pm 1$ \\
\hline $\begin{array}{l}\text { Pennsylvania }{ }^{\text {Pen }} \\
\text { West Virginia }\end{array}$ & 184,682 \\
\hline & 69,000 \\
\hline
\end{tabular}

Table $t$ presents comparative statistics of glass manufacture, by states, for the years 1880,890 , and 1900 .

TABLE 4.-COMPARATIVE STATISTICS, BY STATES: 1880 TO 1900.

\begin{tabular}{|c|c|c|c|c|c|c|c|c|c|c|c|c|c|}
\hline \multirow{3}{*}{ STATES. } & \multirow{3}{*}{ Year. } & \multirow{3}{*}{$\begin{array}{l}\text { Num- } \\
\text { ber of } \\
\text { estab- } \\
\text { lish- } \\
\text { ments. }\end{array}$} & \multirow{3}{*}{ Capital. } & \multicolumn{2}{|c|}{$\begin{array}{l}\text { SALARIED OFFICIAIS, } \\
\text { CIERKS, ETC. }\end{array}$} & \multicolumn{8}{|c|}{ AVERAGE NCMBER OF WAGE-EARNERS AND TOTAL WAGES. } \\
\hline & & & & & & \multicolumn{2}{|c|}{ Total. } & \multicolumn{2}{|c|}{$\begin{array}{c}\text { Men, } 16 \text { years and } \\
\text { over. }\end{array}$} & \multicolumn{2}{|c|}{$\begin{array}{l}\text { Women, } 16 \text { jears } \\
\text { and orer. }\end{array}$} & \multicolumn{2}{|c|}{$\begin{array}{c}\text { Children, under } 16 \\
\text { years. }\end{array}$} \\
\hline & & & & & & $\begin{array}{l}\text { A verage } \\
\text { number. }\end{array}$ & Wages. & $\begin{array}{l}\text { Arerage } \\
\text { number. }\end{array}$ & Wages. & $\begin{array}{l}\text { Average } \\
\text { number. }\end{array}$ & Wages. & $\begin{array}{l}\text { Average } \\
\text { number. }\end{array}$ & Wages. \\
\hline United States....... & $\begin{array}{l}1900 \\
1890 \\
1580\end{array}$ & $\begin{array}{r}355 \\
294 \\
2194\end{array}$ & $\begin{array}{r}\$ 61,423,903 \\
40,966,850 \\
219,329,699\end{array}$ & $\begin{array}{c}2,265 \\
11,095 \\
(3)\end{array}$ & $\begin{array}{c}32,792,376 \\
11,232,561 \\
(3)\end{array}$ & $\begin{array}{l}52,818 \\
41,892 \\
24,177\end{array}$ & $\begin{array}{r}\$ 27,084,710 \\
20,885,961 \\
9,144,100\end{array}$ & $\begin{array}{l}42,173 \\
36,064 \\
17,778\end{array}$ & $\begin{array}{c}\$ 24,901,233 \\
19,546,351 \\
\left({ }^{3}\right)\end{array}$ & $\begin{array}{r}3,529 \\
1,885 \\
741\end{array}$ & $\begin{array}{c}\$ 540,001 \\
332,245 \\
\left({ }^{3}\right)\end{array}$ & $\begin{array}{l}7,116 \\
6,943 \\
5,658\end{array}$ & $\begin{array}{c}\$ 1,343,476 \\
1,007,365 \\
(3)\end{array}$ \\
\hline 1llinois................... & $\begin{array}{l}1900 \\
1590 \\
1880\end{array}$ & $\begin{array}{r}6 \\
18 \\
6\end{array}$ & $\begin{array}{r}2,181,801 \\
1,721,878 \\
425,000\end{array}$ & $\left(^{3}\right)^{75} 31$ & $\begin{array}{c}110,100 \\
44,710 \\
(3)\end{array}$ & $\begin{array}{l}3,304 \\
2,762 \\
732\end{array}$ & $\begin{array}{r}1,621,256 \\
1,188,051 \\
342,027\end{array}$ & $\begin{array}{r}2,607 \\
2,215 \\
682\end{array}$ & $\begin{array}{c}1,496,891 \\
1,121,526 \\
(3)\end{array}$ & $\begin{array}{r}148 \\
20\end{array}$ & $\begin{array}{l}28,456 \\
3,860 \\
(3)\end{array}$ & $\begin{array}{l}549 \\
527 \\
100\end{array}$ & $\begin{array}{l}95,939 \\
62,665 \\
\left({ }^{3}\right)\end{array}$ \\
\hline Indiana................ & $\begin{array}{l}1900 \\
1890 \\
1850\end{array}$ & $\begin{array}{r}110 \\
21 \\
4\end{array}$ & $\begin{array}{r}12,775,389 \\
3,556,563 \\
1,442,000\end{array}$ & $\begin{array}{r}509 \\
\left({ }^{3}\right)^{79}\end{array}$ & $\begin{array}{l}649,227 \\
75,682 \\
\left({ }^{8}\right)\end{array}$ & $\begin{array}{r}13,015 \\
3,010 \\
862\end{array}$ & $\begin{array}{r}7,226,047 \\
1,469,149 \\
284,207\end{array}$ & $\begin{array}{r}10,910 \\
2,633 \\
695\end{array}$ & $\begin{array}{c}6,808,042 \\
1,422,104 \\
\left({ }^{3}\right)\end{array}$ & $\begin{array}{r}634 \\
197 \\
53\end{array}$ & $\begin{array}{c}129,808 \\
27,511 \\
(3)\end{array}$ & $\begin{array}{r}1,471 \\
180 \\
114\end{array}$ & $\begin{array}{c}288,197 \\
19,234 \\
(\mathbf{2})\end{array}$ \\
\hline Kentucky......... & $\begin{array}{r}\$ 1900 \\
51890 \\
1880\end{array}$ & & 795,000 & & 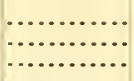 & 522 & 150,322 & 364 & $(3)$ & ii & $(3)$ & 147 & $(z)^{\prime}$ \\
\hline Maryland ................. & $\begin{array}{l}1900 \\
1890 \\
1850\end{array}$ & $\begin{array}{r}7 \\
11 \\
7\end{array}$ & $\begin{array}{l}551,086 \\
871,111 \\
406,000\end{array}$ & (3) $^{31} 16$ & $\begin{array}{l}38,976 \\
12,176 \\
\left({ }^{3}\right)\end{array}$ & $\begin{array}{r}742 \\
1,397 \\
612\end{array}$ & $\begin{array}{l}339,518 \\
696,560 \\
234,254\end{array}$ & $\begin{array}{r}562 \\
1,045 \\
524\end{array}$ & $\begin{array}{c}313,920 \\
650,921 \\
(3)\end{array}$ & $\begin{array}{l}54 \\
24\end{array}$ & $\begin{array}{l}8,673 \\
6,864 \\
(3)\end{array}$ & $\begin{array}{r}126 \\
328 \\
88\end{array}$ & $\begin{array}{l}16,925 \\
38,775 \\
\left.{ }^{3}\right)\end{array}$ \\
\hline Massachusetts ........... & $\begin{array}{l}1900 \\
1890 \\
1880\end{array}$ & $\begin{array}{r}5 \\
6 \\
10\end{array}$ & $\begin{array}{l}258,949 \\
365,051 \\
723,000\end{array}$ & $\begin{array}{l}39 \\
\text { (9) } \\
18\end{array}$ & $\begin{array}{l}28,060 \\
17,774 \\
(3)\end{array}$ & $\begin{array}{l}387 \\
496 \\
946\end{array}$ & $\begin{array}{l}188,674 \\
201,653 \\
353,342\end{array}$ & $\begin{array}{l}343 \\
455 \\
828\end{array}$ & $\begin{array}{c}179,236 \\
195,221 \\
\text { (अ) }\end{array}$ & $\begin{array}{l}19 \\
19 \\
58\end{array}$ & $\begin{array}{l}4,392 \\
3,732 \\
(3)\end{array}$ & $\begin{array}{l}25 \\
22 \\
60\end{array}$ & $\begin{array}{l}5,046 \\
2,700 \\
(3)\end{array}$ \\
\hline Missouri ................. & $\begin{array}{l}1900 \\
1890 \\
1880\end{array}$ & $\begin{array}{l}3 \\
5 \\
6\end{array}$ & $\begin{array}{l}2,198,316 \\
2,201,353 \\
1,430,000\end{array}$ & $\left(^{26} \begin{array}{r}26 \\
39\end{array}\right.$ & $\begin{array}{l}47,448 \\
54,082 \\
(3)\end{array}$ & $\begin{array}{r}650 \\
1,113 \\
965\end{array}$ & $\begin{array}{l}341,375 \\
542,157 \\
381,095\end{array}$ & $\begin{array}{r}648 \\
1,016 \\
709\end{array}$ & $\begin{array}{c}340,825 \\
524,373 \\
\left({ }^{3}\right)\end{array}$ & & ........... & $\begin{array}{r}2 \\
97 \\
220\end{array}$ & ${ }_{(3)}^{17,784}$ \\
\hline New Jersey ..... & $\begin{array}{l}1900 \\
1890 \\
1850\end{array}$ & $\begin{array}{l}26 \\
34 \\
22\end{array}$ & $\begin{array}{l}5,397,662 \\
3,744,894 \\
2,568,021\end{array}$ & 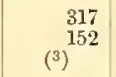 & $\begin{array}{c}284,960 \\
132,619 \\
(3)\end{array}$ & $\begin{array}{l}5,383 \\
5,688 \\
3,578\end{array}$ & $\begin{array}{l}2,462,745 \\
2,730,100 \\
1,300,038\end{array}$ & $\begin{array}{l}4,366 \\
4,601 \\
2,762\end{array}$ & $\begin{array}{c}2,278,306 \\
2,605,798 \\
\left(^{(3)}\right.\end{array}$ & $\begin{array}{r}170 \\
42 \\
46\end{array}$ & $\begin{array}{c}32,726 \\
\delta, 405 \\
(3)\end{array}$ & $\begin{array}{r}847 \\
1,045 \\
770\end{array}$ & $\begin{array}{l}151,713 \\
115,897 \\
\left({ }^{8}\right)\end{array}$ \\
\hline New York ................. & $\begin{array}{l}1900 \\
1890 \\
1880\end{array}$ & $\begin{array}{l}27 \\
30 \\
29\end{array}$ & $\begin{array}{l}2,242,834 \\
2,297,699 \\
1,875,600\end{array}$ & $\begin{array}{r}117 \\
56\end{array}$ & $\begin{array}{l}139,698 \\
61,413 \\
\left({ }^{8}\right)\end{array}$ & $\begin{array}{l}2,556 \\
3,229 \\
3,078\end{array}$ & $\begin{array}{l}1,305,264 \\
1,422,626 \\
1,046,812\end{array}$ & $\begin{array}{l}2,201 \\
2,587 \\
2,116\end{array}$ & $\begin{array}{c}1,239,971 \\
1,319,607 \\
(3)\end{array}$ & $\begin{array}{l}73 \\
92 \\
50\end{array}$ & $\begin{array}{c}17,831 \\
17,025 \\
(3)\end{array}$ & $\begin{array}{l}282 \\
650 \\
912\end{array}$ & $\begin{array}{l}47,462 \\
85,994 \\
(3)\end{array}$ \\
\hline Ohio.................. & $\begin{array}{l}1900 \\
1590 \\
1850\end{array}$ & $\begin{array}{l}25 \\
59 \\
19\end{array}$ & $\begin{array}{l}5,451,513 \\
4,094,675 \\
1,172,850\end{array}$ & ${ }_{(3)^{199}}$ & $\begin{array}{l}249,029 \\
230,323 \\
(3)\end{array}$ & $\begin{array}{l}4,546 \\
6,435 \\
1,688\end{array}$ & $\begin{array}{r}2,067,354 \\
2,901,255 \\
644,520\end{array}$ & $\begin{array}{l}3,505 \\
5,053 \\
1,170\end{array}$ & $\begin{array}{c}1,814,958 \\
2,700,036 \\
(3)\end{array}$ & $\begin{array}{r}405 \\
538 \\
81\end{array}$ & $\begin{array}{c}36,017 \\
74,227 \\
(3)\end{array}$ & $\begin{array}{l}636 \\
544 \\
437\end{array}$ & $\begin{array}{l}126,409 \\
126,992 \\
\text { (3) }\end{array}$ \\
\hline Pennsyltanis............. & $\begin{array}{l}1900 \\
1890 \\
1850\end{array}$ & $\begin{array}{r}119 \\
99 \\
7\end{array}$ & $\begin{array}{r}2 S, 287,187 \\
20,459,049 \\
7,609,706\end{array}$ & 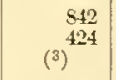 & $\begin{array}{c}1,110,343 \\
518,610 \\
(3)\end{array}$ & $\begin{array}{r}19,420 \\
18,510 \\
9,784\end{array}$ & $\begin{array}{r}10,287,491 \\
8,728,520 \\
3,397,306\end{array}$ & $\begin{array}{r}15,136 \\
14,524 \\
6,999\end{array}$ & $\begin{array}{c}9,335,261 \\
8,090,926 \\
\left({ }^{3}\right)\end{array}$ & $\begin{array}{r}1,546 \\
749 \\
294\end{array}$ & $\begin{array}{c}414,250 \\
154,689 \\
(3)\end{array}$ & $\begin{array}{l}2,738 \\
2,937 \\
2,491\end{array}$ & $\begin{array}{l}534,980 \\
482,905 \\
\left({ }^{3}\right)\end{array}$ \\
\hline West Virginin............. & $\begin{array}{l}1900 \\
1890 \\
1880\end{array}$ & $\begin{array}{r}16 \\
7 \\
4\end{array}$ & $\begin{array}{r}1,338,081 \\
825,313 \\
550,522\end{array}$ & 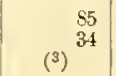 & $\begin{array}{l}97,551 \\
46,946 \\
\left({ }^{3}\right)\end{array}$ & $\begin{array}{r}1,949 \\
1,371 \\
946\end{array}$ & $\begin{array}{l}789,422 \\
511,079 \\
311,650\end{array}$ & $\begin{array}{r}1,319 \\
-\quad 970 \\
615\end{array}$ & $\begin{array}{l}657,984 \\
446,349 \\
\text { ( })\end{array}$ & $\begin{array}{l}468 \\
190 \\
100\end{array}$ & $\begin{array}{c}103,748 \\
32,632 \\
(3)\end{array}$ & $\begin{array}{l}162 \\
211 \\
231\end{array}$ & $\begin{array}{l}2 \pi, 690 \\
32,098 \\
\left({ }^{3}\right)\end{array}$ \\
\hline All other states $6 . . . . . . .$. & $\begin{array}{l}1900 \\
1890 \\
1880\end{array}$ & $\begin{array}{l}8 \\
9 \\
6\end{array}$ & $\begin{array}{l}711,082 \\
829,262 \\
332,000\end{array}$ & 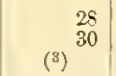 & $\begin{array}{l}36,911 \\
38,196 \\
(3)\end{array}$ & $\begin{array}{l}866 \\
851 \\
164\end{array}$ & $\begin{array}{l}455,504 \\
494,811 \\
165,524\end{array}$ & $\begin{array}{l}576 \\
665 \\
364\end{array}$ & $\begin{array}{c}402,839 \\
469,490 \\
\left({ }^{8}\right)\end{array}$ & $\begin{array}{l}12 \\
14 \\
12\end{array}$ & $\begin{array}{l}4,100 \\
3,000 \\
(3)\end{array}$ & $\begin{array}{r}278 \\
202 \\
88\end{array}$ & $\begin{array}{l}48,565 \\
22,321 \\
(3)\end{array}$ \\
\hline
\end{tabular}

1 Includes proprietors and firm members, with their salaries; number only reported in 1900 but not included in this table. (See Table 12. ) 2 Includes 25 establishments idle or in process of construction, with a capital of $\$ 525,100$. Not separately reported by states in 1850 .

3 Not reported separately.

No establishments reported.

Includes establishments distributed as follows: 1900-California, 1; Colorado, 1; Delaware, 1; Georgia, 1; Michigan, 1; Virginia, 2; Wisconsin, 1. 1890-California, 1; Colorado, 1; Delaware. 1; Georgia, 2; Kentuchy, 2: Michigan, 1; Wisconsin, 1. 1sso-California, 1; Connecticut, 1; lowa, 1; Michigan, 1; New Hampshire, 1. 
TABLE 4.-COMPARATIVE STATISTICS, BY STATES: 1880 TO 1890-Continued.

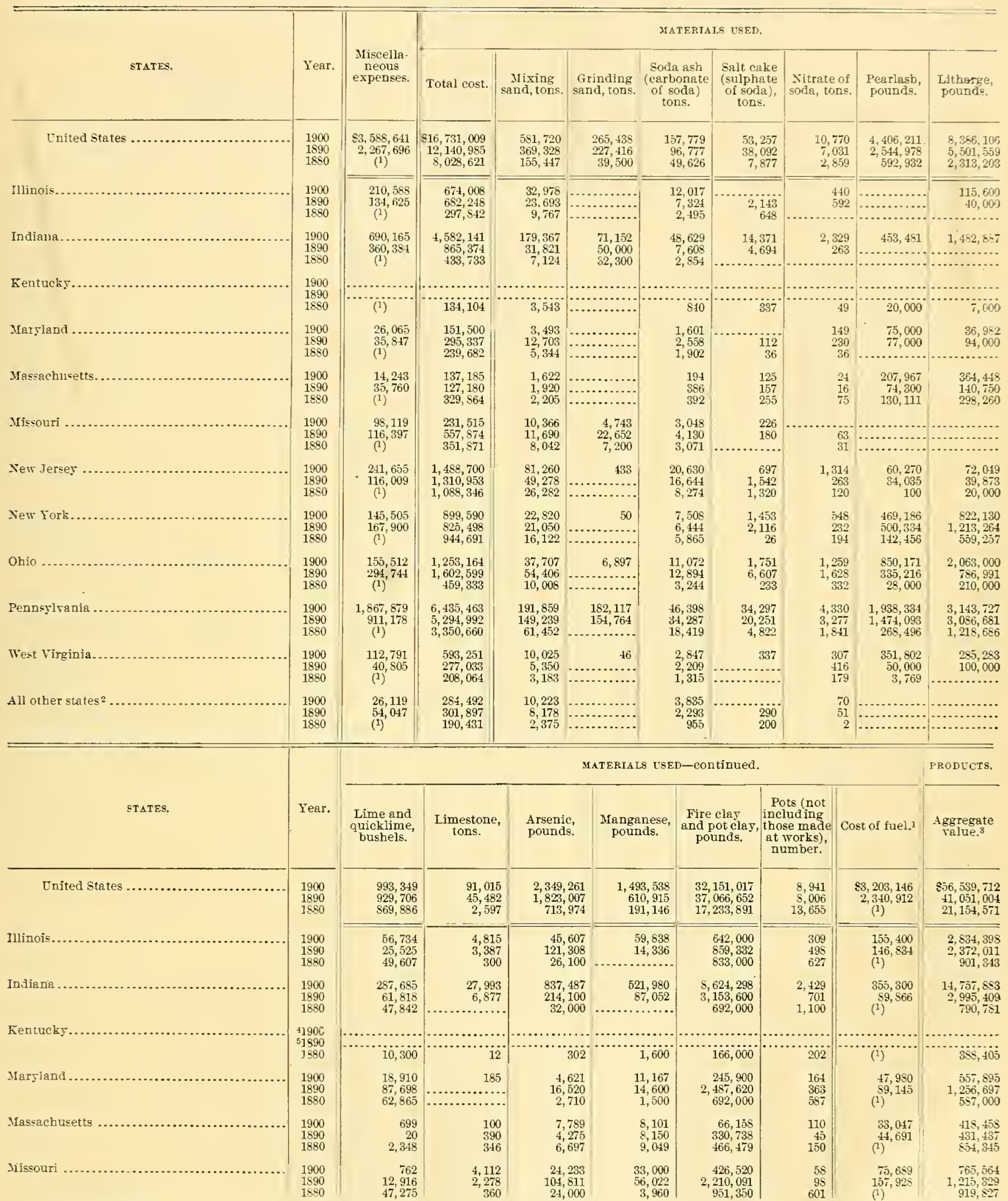

1. Not reported in 1880 .

$\begin{array}{rrr}12,916 & 2,278 & 104,81 \\ 47,275 & 360 & 24,000\end{array}$

$\begin{array}{r}6,022 \\ 3,960\end{array} \quad 2,210,091$

601

(1)

919,827

forncludes establishments distributed as follows: 1900-California, 1; Colorado, 1; Delaware, 1; Georgia, 1; Michigan, 1; Virginia, 2; Iriscousin, 1. 1890-Cali

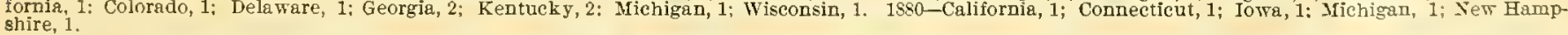

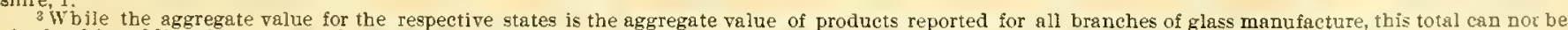

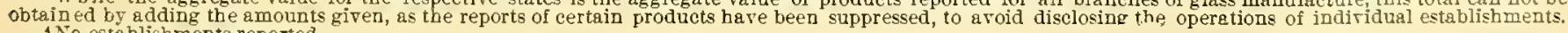
4 No establishments reported. 
TABLE 4.-COMPARATIVE STATISTICS, BY STATES: 1850 TO 1900-Continued.

\begin{tabular}{|c|c|c|c|c|c|c|c|c|c|}
\hline \multirow[b]{2}{*}{ STATES. } & \multirow[b]{2}{*}{ Year. } & \multicolumn{7}{|c|}{ MATERIALS LSED-continued. } & \multirow{2}{*}{$\begin{array}{c}\text { Products. } \\
\begin{array}{c}\text { Aggregate } \\
\text { ralue.2 }\end{array}\end{array}$} \\
\hline & & $\begin{array}{l}\text { Lime and } \\
\text { qulicklime, } \\
\text { busbels. }\end{array}$ & $\begin{array}{l}\text { Limestome, } \\
\text { tons. }\end{array}$ & $\begin{array}{l}\text { Arsenic, } \\
\text { ponnds. }\end{array}$ & $\begin{array}{l}\text { Manganese, } \\
\text { pounds. }\end{array}$ & $\begin{array}{c}\text { Fire clay } \\
\text { and pot elay, } \\
\text { pounds. }\end{array}$ & $\begin{array}{c}\text { Pots (not } \\
\text { including } \\
\text { those made } \\
\text { at works), } \\
\text { number. }\end{array}$ & Cost of fuel. 1 & \\
\hline New Jersey ....... & $\begin{array}{l}1900 \\
1890 \\
1580\end{array}$ & $\begin{array}{l}248,654 \\
198,086 \\
174,680\end{array}$ & $\begin{array}{r}8,577 \\
3,397 \\
455\end{array}$ & $\begin{array}{r}102,490 \\
75,256 \\
35,453\end{array}$ & $\begin{array}{r}143,465 \\
17,065 \\
12,000\end{array}$ & $\begin{array}{l}2,108,845 \\
3,841,290 \\
2,850,998\end{array}$ & $\begin{array}{r}366 \\
518 \\
2,118\end{array}$ & $\begin{array}{l}415,828 \\
384,951 \\
\text { (1) }\end{array}$ & $\begin{array}{l}5,093,822 \\
5,215,152 \\
2,810,170\end{array}$ \\
\hline 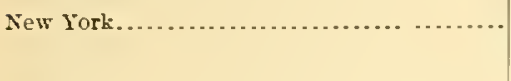 & $\begin{array}{l}1900 \\
1890 \\
1880\end{array}$ & $\begin{array}{l}41,024 \\
90,502 \\
98,534\end{array}$ & $\begin{array}{r}2,462 \\
778 \\
\cdots \cdots\end{array}$ & $\begin{array}{r}101,570 \\
52,026 \\
6,600\end{array}$ & $\begin{array}{l}90,721 \\
32,489 \\
27,505\end{array}$ & $\begin{array}{l}1,033,200 \\
2,775,35.5 \\
1,537,650\end{array}$ & $\begin{array}{r}475 \\
450 \\
1,661\end{array}$ & $\begin{array}{l}227,153 \\
241,893 \\
(1)\end{array}$ & $\begin{array}{l}2,736,978 \\
2,723,019 \\
2,420,796\end{array}$ \\
\hline Ohio........... & $\begin{array}{l}1900 \\
1590 \\
1550\end{array}$ & $\begin{array}{r}94,547 \\
108,597 \\
45,635\end{array}$ & $\begin{array}{r}3,356 \\
6,932 \\
\cdots\end{array}$ & $\begin{array}{r}228,587 \\
375,196 \\
25,916\end{array}$ & $\begin{array}{r}76,117 \\
124,581 \\
16,436\end{array}$ & $\begin{array}{r}2,549,910 \\
7,141,275 \\
848,025\end{array}$ & $\begin{array}{r}1,199 \\
1,780 \\
835\end{array}$ & $\begin{array}{l}249,405 \\
156,404 \\
(1)\end{array}$ & $\begin{array}{l}4,547,083 \\
5,649,152 \\
1,549,320\end{array}$ \\
\hline Pennsylvania . . . . . . . . & $\begin{array}{l}1900 \\
1890 \\
1880\end{array}$ & $\begin{array}{l}1 S 4,969 \\
265,674 \\
309,122\end{array}$ & $\begin{array}{r}38,309 \\
20,243 \\
1,121\end{array}$ & $\begin{array}{l}896,074 \\
746,393 \\
547,266\end{array}$ & $\begin{array}{l}457,581 \\
216,910 \\
110,178\end{array}$ & $\begin{array}{r}15,926,246 \\
13.086,293 \\
6,495,169\end{array}$ & $\begin{array}{l}3,461 \\
3,223 \\
5,170\end{array}$ & $\begin{array}{l}1,421,710 \\
858,281 \\
\text { (1) }\end{array}$ & $\begin{array}{r}22,011,130 \\
17,179,137 \\
8,720,584\end{array}$ \\
\hline West Virginia............... & $\begin{array}{l}1900 \\
1590 \\
1850\end{array}$ & $\begin{array}{r}19,660 \\
14,107 \\
7,533\end{array}$ & 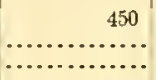 & $\begin{array}{r}80,503 \\
89,822 \\
\ldots \ldots \ldots\end{array}$ & $\begin{array}{r}58,944 \\
16,450 \\
8,518\end{array}$ & $\begin{array}{l}154,940 \\
662,550 \\
933,720\end{array}$ & $\begin{array}{l}350 \\
170 \\
332\end{array}$ & $\begin{array}{c}88,905 \\
54,895 \\
(1)\end{array}$ & $\begin{array}{r}1,871,795 \\
945,234 \\
748,500\end{array}$ \\
\hline All other states ${ }^{3} . .$. & $\begin{array}{l}1900 \\
1890 \\
1850\end{array}$ & $\begin{array}{l}39,705 \\
61,763 \\
13,825\end{array}$ & $\begin{array}{r}656 \\
1,195 \\
.2 . \ldots .\end{array}$ & $\begin{array}{r}20,300 \\
23,300 \\
930\end{array}$ & $\begin{array}{r}32,624 \\
23,260 \\
400\end{array}$ & $\begin{array}{l}373,000 \\
518,500 \\
437,500\end{array}$ & $\begin{array}{r}20 \\
160 \\
272\end{array}$ & $\begin{array}{l}102,724 \\
113,034 \\
(1)\end{array}$ & $\begin{array}{r}924,706 \\
1,065,397 \\
463,500\end{array}$ \\
\hline
\end{tabular}

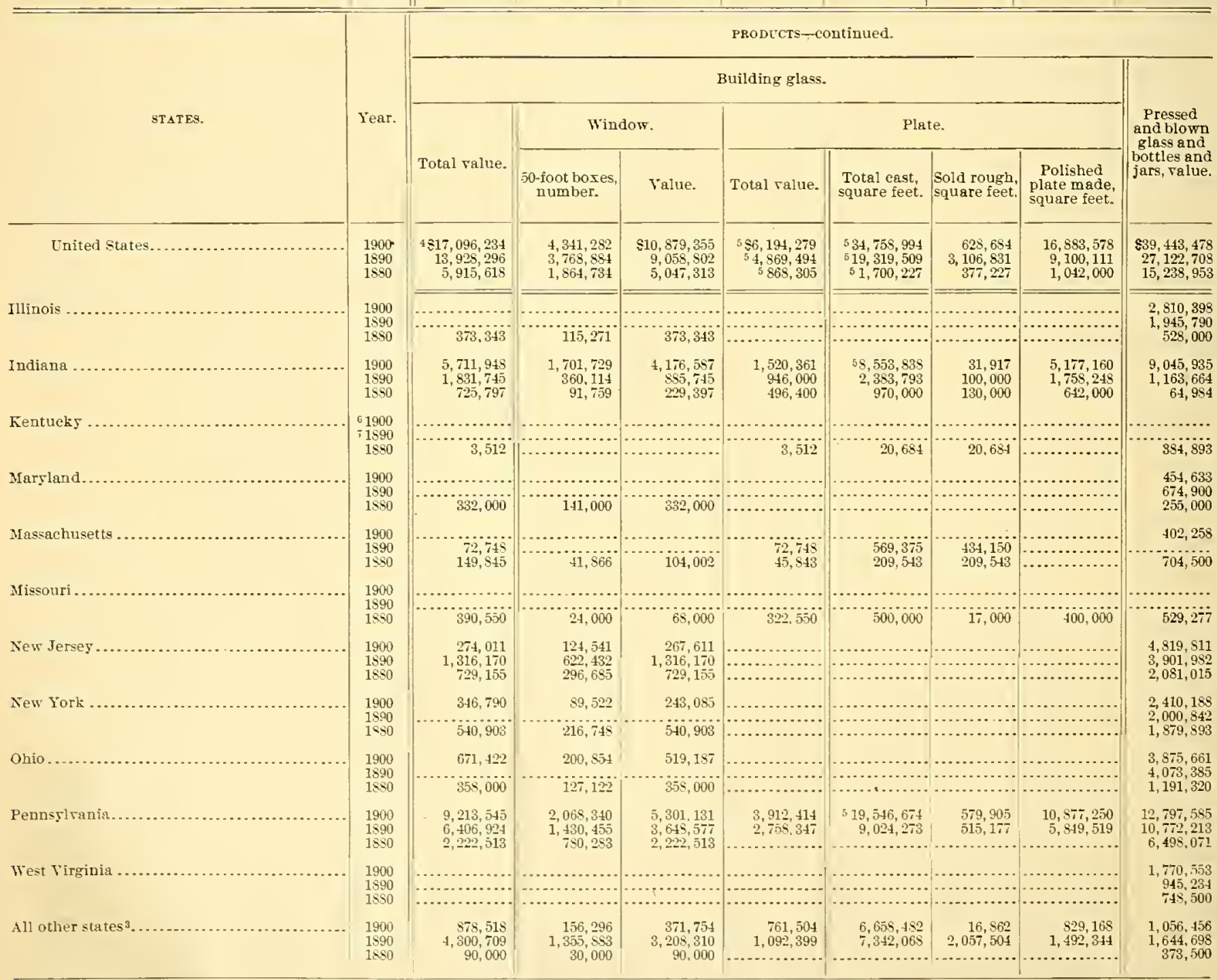

1 Not reported in 1850 ,

2 While the aggregate ralue for the respectire states is the aggregate ralue of produets reported for all branebes of glass manufacture, tbis total ean not be obtained by adding the amounts giren, as the reports of certain products hare been suppressed, to aroid disclosing the operations of indiridual establishments. 3Ineludes establishments distributed as follows: 1900-California, 1: Colorado, 1: Delaware, 1: Georgia, 1; Michigan, 1: Yirginia, 2; Wisconsin: 1. 1890-Cali-
fornia, 1; Colorado, 1: Delaware, 1; Georgia, 2: Kentueky, 2; Xichigau, 1; Wisconsin, 1. 1sso-California, 1: Couneetieut, 1: 1owa, 1; Michigan, 1: Yew Hamp-

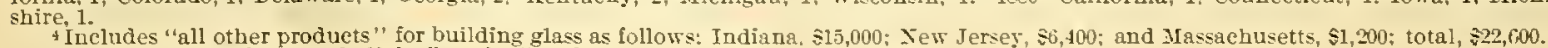

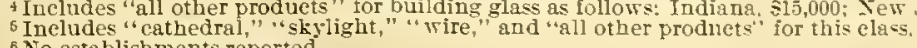

5o establishments reported.
included in "all other states." 
TABLE 1.-COMPARATIVE STATISTICS, BY STATES: 1880 TO 1900-Continued.

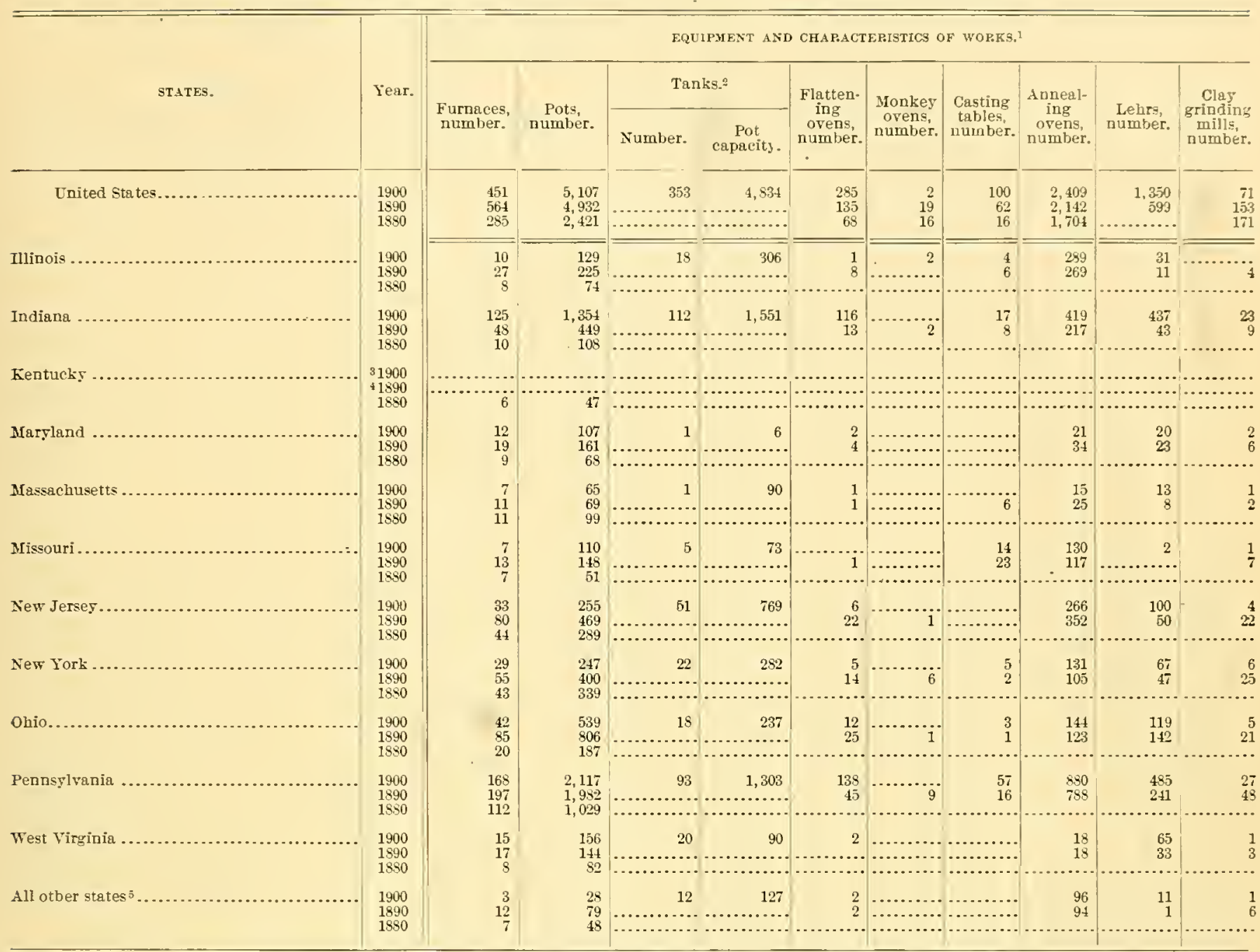

EQUIPMENT AND CHARACTERISTICS OF WORKS-continued.

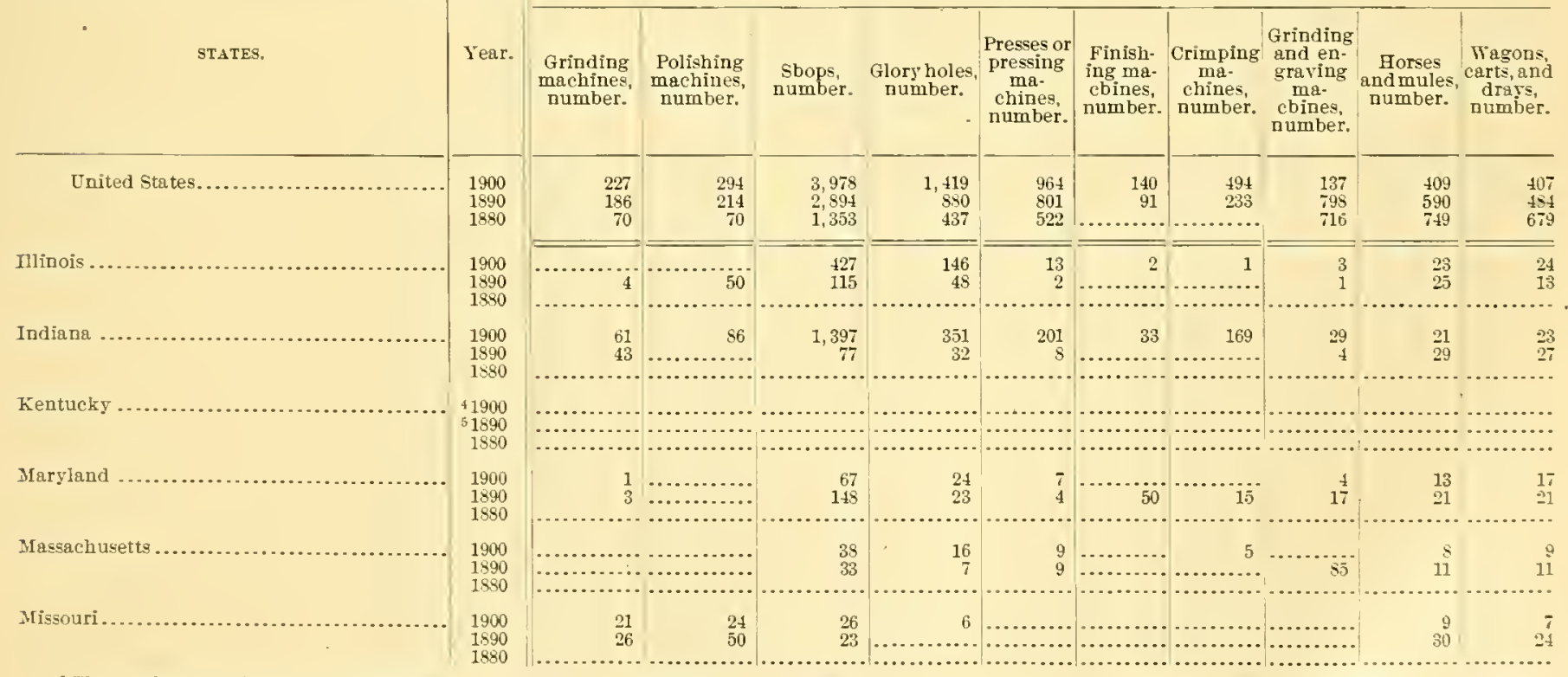

1 The equipment of glass manufacturing plants, otber than furnaces and pots, not haring been reported by state totals in $18 s 0$, the comparison can be made only for the United States for tbat year.

Not reported in 1880 and 1890.

"Included in "all otber states."

"Included in "all otber states""

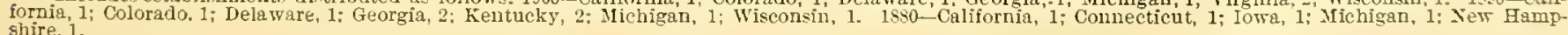


TABLE 4.-COMPAR.ATIVE ST.ATISTICS, BY STATES: 1880 TO 1900-Continued.

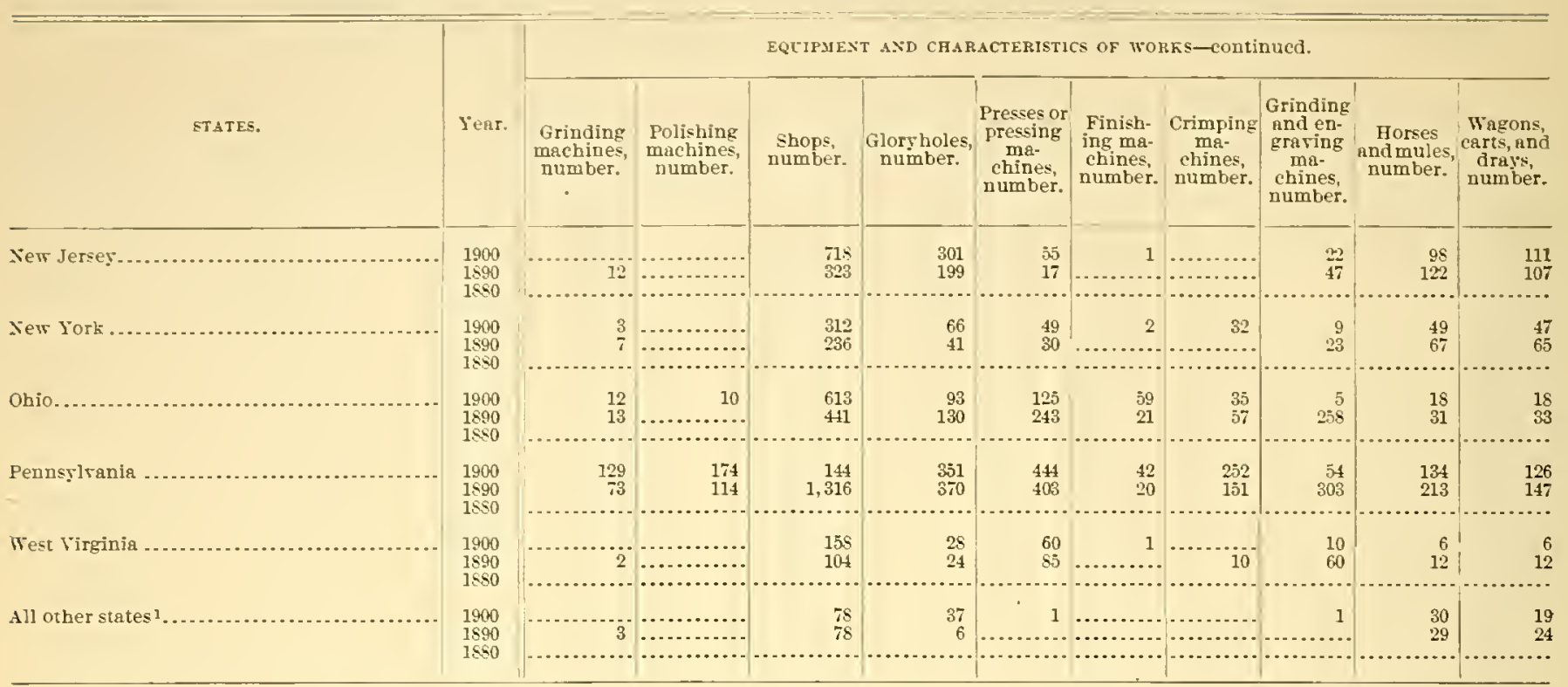

Table 5 presents comparative statistics of glass man- $\mid 1890$, and 1900 , with the per cent of increase for each ufacture, by classes of products, for the years 1880, decade.

Table 5.-COMPARATIVE SUMMARY, BY ClASSES OF PRODUCTS, 1880 TO 1900, WITH PER CENT OF INCREASE FOR EACH DECADE,

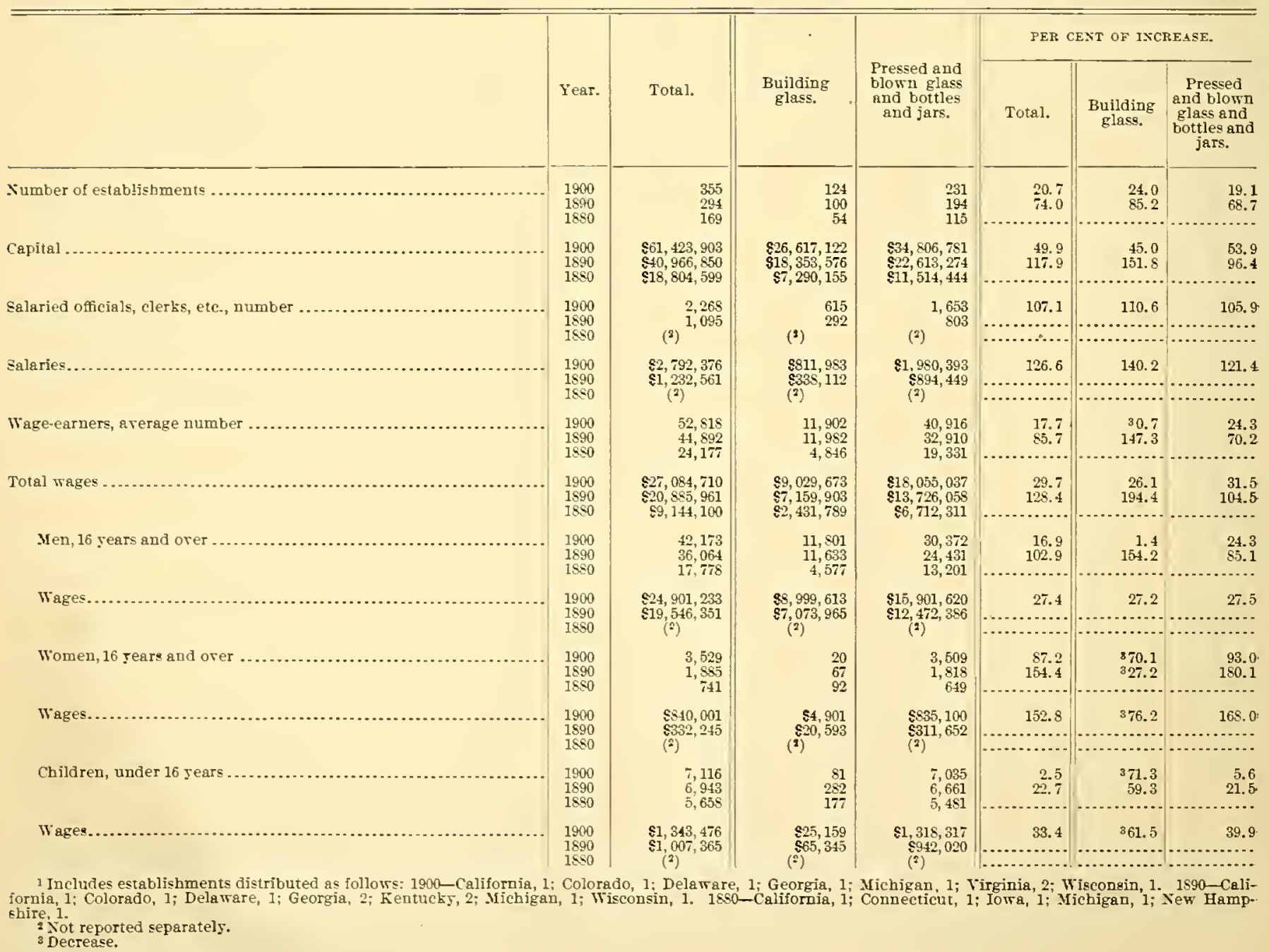


TABLE 5.-COMPARATIVE SUMMARY, BY CLASSES OF PRODUCTS, 1880 TO 1900, WITH PER CENT OF INCREASE FOR EACH DECADE-Continued.

\begin{tabular}{|c|c|c|c|c|c|c|c|}
\hline \multirow{2}{*}{. } & \multirow[b]{2}{*}{ Year. } & \multirow[b]{2}{*}{ Total. } & \multirow[b]{2}{*}{$\begin{array}{l}\text { Building } \\
\text { glass. }\end{array}$} & \multirow[b]{2}{*}{$\begin{array}{l}\text { Pressed and } \\
\text { blown glass } \\
\text { and bottles } \\
\text { and jars. }\end{array}$} & \multicolumn{3}{|c|}{ PEF CEXT OF ISICEEASE. } \\
\hline & & & & & Total. & $\begin{array}{l}\text { Buildihg } \\
\text { glass. }\end{array}$ & $\begin{array}{c}\text { Pressed } \\
\text { and blown } \\
\text { glass and } \\
\text { bottles and } \\
\text { jars. }\end{array}$ \\
\hline Miscellaneous expenses......... & $\begin{array}{l}1900 \\
1890 \\
1880\end{array}$ & $\begin{array}{l}\$ 3,588,641 \\
\$ 2,267,696 \\
(1)\end{array}$ & $\begin{array}{l}\$ 1,365,865 \\
\$ 1,069,545 \\
\text { (') }\end{array}$ & $\begin{array}{l}\$ 2,222,776 \\
\$ 1,198,151 \\
\quad(1)\end{array}$ & $\begin{array}{l}58.3 \\
\ldots \ldots . \\
\cdots \ldots\end{array}$ & 27.7 & $\begin{array}{l}85.5 \\
\cdots . .\end{array}$ \\
\hline Cost of materials used............ & $\begin{array}{l}1900 \\
1890 \\
1880\end{array}$ & $\begin{array}{r}\$ 16,731,009 \\
\$ 12,140,985 \\
\$ 8,028,621\end{array}$ & $\begin{array}{l}\$ 4,679,084 \\
\$ 4,621,535 \\
\$ 2,287,987\end{array}$ & $\begin{array}{r}\$ 12,051,925 \\
87,519,450 \\
\$ 5,740,634\end{array}$ & $\begin{array}{r}37.8 \\
51.2 \\
\cdots \cdots\end{array}$ & $\begin{array}{r}1.2 \\
102.0 \\
1.2 .\end{array}$ & $\begin{array}{l}60.3 \\
31.0\end{array}$ \\
\hline Value of products. ............... & $\begin{array}{l}1900 \\
1890 \\
1880\end{array}$ & $\begin{array}{l}\$ 56,539,712 \\
\$ 41,051,004 \\
\$ 21,154,571\end{array}$ & $\begin{array}{r}\$ 17,096,234 \\
\$ 13,928,296 \\
\$ 5,915,618\end{array}$ & $\begin{array}{l}\$ 39,443,478 \\
\$ 27,122,708 \\
\$ 15,238,953\end{array}$ & $\begin{array}{l}37.7 \\
94.1 \\
\cdots . . .\end{array}$ & $\begin{array}{r}22.7 \\
135.4\end{array}$ & $\frac{45.4}{78.0}$ \\
\hline Pot and tank furnaces, number... & $\begin{array}{l}1900 \\
1890 \\
1880\end{array}$ & $\begin{array}{l}804 \\
564 \\
285\end{array}$ & $\begin{array}{r}241 \\
195 \\
82\end{array}$ & $\begin{array}{l}563 \\
369 \\
203\end{array}$ & $\begin{array}{r}42.6 \\
97.9 \\
\cdots \cdots\end{array}$ & $\begin{array}{r}23.6 \\
137.8\end{array}$ & $\begin{array}{l}52.6 \\
81.8\end{array}$ \\
\hline Pot capacity of furnaces, number & $\begin{array}{l}1900 \\
1890 \\
1880\end{array}$ & $\begin{array}{l}9,941 \\
4,932 \\
2,421\end{array}$ & $\begin{array}{r}3,726 \\
2,024 \\
741\end{array}$ & $\begin{array}{l}6,215 \\
2,408 \\
1,680\end{array}$ & $\begin{array}{r}101.6 \\
103.7 \\
\ldots \ldots \ldots .\end{array}$ & $\begin{array}{r}84.1 \\
173.1 \\
\cdots\end{array}$ & $\begin{array}{r}113.7 \\
73.1 \\
\ldots\end{array}$ \\
\hline
\end{tabular}

Tables 4 and 5 show large increases in the number of salaried officials and their salaries, between 1890 and 1900 , caused by the organization of large consolidations in the glass business within the last five years. The most interesting disclosure, howerer, is the widespread substitution of the tank for the pot furnace for melting glass. No statistics of tank furnaces appear in the report on glass manufacture at the census of 1890 , although a number were in existence at that time. These tanks were then largely regarded as in the experimental stage, although it had been demonstrated in 1858 that their operation was a success, particularly in the manufacture of window glass. It was several years before glass manufacturers rere convinced of the advantages of the tank over the pot furnace; but from 1890 on, the introduction of the tank has been steady and is the prominent feature of the progress of the American glass industry during the last decade. A larger production and a more miform quality of glass are rendered possible by the usc of the tank system of melting than by the pot-furnace system, especially in the manufacture of window glass and bottles and jars. Although the cost of the installation of the tank systcm is considerably greater than that of the pot system, the former is much more economical and regular in operation. In many departments of the glass industry it meets the demand for more glass for less money. The introduction of the continuous tank in the manufacture of bottles and jars has been fully as general as in the manufacture of window glass, and continuous and intermittent or day tanks are being mole and more extensively used in the manufacture of common tumblers and jellies, opal ware, lantern globes, lamp founts, chimneys, shades, and globes, and novelties and specialties in pressed and blown ware.
The statistics of furnaces are of little value for comparative purposes, owing to the general introduction of the tank furnace during the last decade. The following comparisons have been made on the assumption that all furnaces reported in 1890 were pot furnaces; this is not strictly correct, as it is known that there were several tank furnaces in operation at that time, but they wcre not shown separately in the published statistics. The number of tank furnaces reported was small, however, and would not materially affect the comparisons.

Since 1890 there has been a decrease of 20 per cent in the total number of pot furnaces, 564 being reported in 1890 and 451 in 1900 . In building glass, 195 pot furnaces were reported in 1890 and 193 in 1900 , a dccrease of only 2 , while the decrease in the number of pot furnaces for pressed and blewn glass and bottles and jars was 111 , or 30.1 per cent, $36 \%$ being reported in 1890 and 258 in 1900 . However, in 1900 there is a total increase for the United States of 353 tanks-206 continuous and 147 day-making a gain in the total number of melting furnaces in 1900 over 1890 of 240 , or 42.6 per cent. In building glass, 34 continuous and 14 day tanks were reported in 1900 , making an increase in the total number of furnaces for that class in 1900 of 23.6 per cent over the number reported in 1890 . In the class of pressed and blown ware and bottles and jars, 172 continuous and 133 day tanks were reported in 1900 , making a gain of 52.6 per cent in the total number of furnaces in that division in 1900 orer the total for 1890 .

By estimating the ring capacity of the continuous tank in building glass establishments as equal to 3 pots, and in pressed and blown glass and bottle and jar establishments as equal to 2 pots, and estimating the 
ton capacity of the dar tank in both classes as equal to a like pot capacitr, the 353 tanks have a total capacity of $4,83 \pm$ pots, 1,430 of mhich are in building glass factories and $3, \pm 0 \pm$ in pressed and blown glass and bottle and jar factories. A comparison of the capacity of the pot furnaces reported in 1900 with the capacity reported in 1890 , shows an increase in capacity of 3.5 per cent; an increase in building glass capacity of 13.4 per cent; and a decrease in pressed and blown warc and bottle and jar capacity of 3.3 per cent. Howerer, the total capacity of both pot furnaces and tanks for the entire industry in 1900 increased 101.6 per ceut over 1890; of building glass capacity, St.1 per cent; and of pressed and blown ware and bottles and jars, 113.7 per cent. The increase of only 23.6 per cent in the number of furnaces in building glass factories, with an increase of 84.1 per cent in the pot capacity, indicates the much larger capacity of the arerage window tank than that of the tank used in the production of pressed and blown ware and bottles and jar's, where the number of furnaces incleased 52.6 per cent and the pot capacity increised 113.7 per cent. The day tank in building glass factories is used in the manutacture of skylight, tile glass, etc.

The general introduction of the tank for glass melting has created, within the past decade, a separate industry of considerable magnitude--the preparation of the clay for the construction of tanks. At the sanre time the manufacture of the glass melting pot has been transferred largely fron the glass factory to a few establishments that make a specialty of its manufacture.

Table 6 presents the rank of states in glass manufacture as a whole from 1850 to 1890 , according to value of products, with the percentages of total value of products for the United States.

TABle 6.-RANK OF STATES ACCORDING TO VALUE OF PRODUCTS: 1880 TO 1900, WITH PER CENT OF TOTAL VALUE.

\begin{tabular}{|c|c|c|c|c|c|c|c|c|c|}
\hline \multirow{2}{*}{ STATES. } & \multicolumn{3}{|c|}{ RANK. } & \multicolumn{3}{|c|}{ VALEE OF PRODUCTS. } & \multicolumn{3}{|c|}{ PER CENT OF TOTAL VALUE. } \\
\hline & 1900 & 1590 & 1880 & 1900 & 1590 & 1580 & 1900 & 1890 & 1880 \\
\hline United States.... & & & 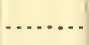 & $\$ 56,539,712$ & $\$ 41,051,004$ & \$ $21,154,571$ & 100.0 & 100.0 & 100.0 \\
\hline 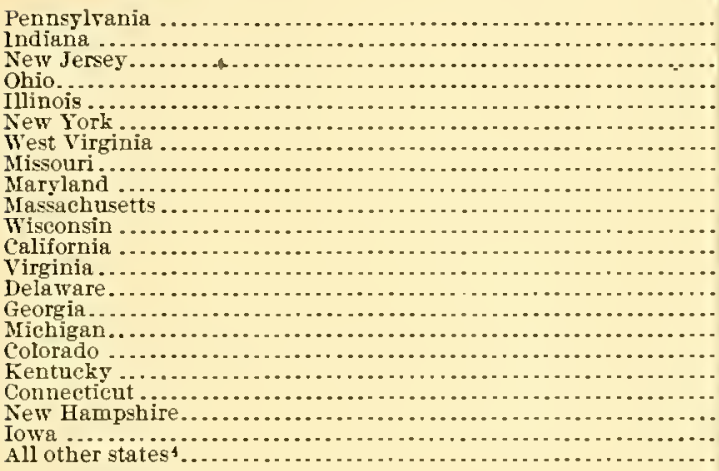 & $\begin{array}{r}1 \\
2 \\
3 \\
4 \\
5 \\
6 \\
7 \\
5 \\
9 \\
10 \\
11 \\
12 \\
13 \\
14 \\
15 \\
16 \\
17 \\
\ldots \ldots . . \\
\ldots \ldots . . \\
\ldots . .\end{array}$ & $\begin{array}{r}1 \\
4 \\
3 \\
2 \\
6 \\
5 \\
9 \\
8 \\
7 \\
10 \\
13 \\
14 \\
16 \\
12 \\
17 \\
15 \\
11 \\
\ldots \ldots . . . \\
\ldots \ldots . . .\end{array}$ & 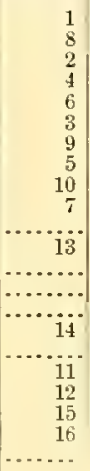 & $\begin{array}{r}22,011,130 \\
14,757,853 \\
5,093,822 \\
4,547,083 \\
2,834,398 \\
2,756,978 \\
1,871,795 \\
765,564 \\
557,595 \\
418,458 \\
(1) \\
(1) \\
(1) \\
(1) \\
(1) \\
1) \\
(2) \\
(2) \\
(2) \\
(2) \\
924,706\end{array}$ & $\begin{array}{r}17,179,137 \\
2,995.409 \\
5,218,152 \\
5,649,182 \\
2,372,011 \\
2,723,019 \\
945,234 \\
1,215,329 \\
1,256,697 \\
431,437 \\
(1) \\
(1) \\
(2) \\
(1) \\
(1) \\
1 \\
11 \\
10 \\
0 \\
2 \\
22 \\
1,065,397\end{array}$ & $\begin{array}{r}8,720,584 \\
790,781 \\
2,810,170 \\
1,519,320 \\
901,343 \\
2,420,796 \\
745,500 \\
919,827 \\
587,000 \\
854,345 \\
(2) \\
140,000 \\
(2) \\
(2) \\
90 \\
90,000 \\
(2) \\
358,405 \\
160,000 \\
70,000 \\
3,500 \\
\ldots . . . \ldots .\end{array}$ & 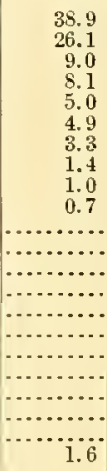 & $\begin{array}{r}41.8 \\
7.3 \\
12.7 \\
13.8 \\
5.8 \\
6.6 \\
2.3 \\
3.0 \\
3.1 \\
1.0 \\
\ldots \ldots . .\end{array}$ & 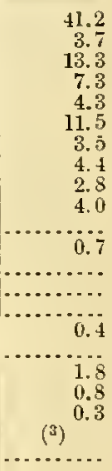 \\
\hline
\end{tabular}

1 Included in " all other states."

Not reported.

8 Less than one-tenth of 1 per cent.

Includes the following states: 1890-California, Colorado, Delaware, Georgia, Kentuckr, Michigan, Wisconsin; 1900-California, Colorado, Delaware, Georgia, Michigan, Virginia, Wisconsin.

Glass manufacture was reported in 17 states in 1900 ; in 17 , in 1890; and in 16. in 1880 . Wisconsiu. Viroinia, Delaware, Georgia, and Colorado were not reported in 1850. Iowa, New Hampshire, and Connecticut dropped out of the producing column in 1590. but Wisconsin, Delaware, Georgia, and Colorado were added. In 1900, Virginia, the home of the first glass factory. was again reported. No reports of glass manufacture were made from Kentucky in 1900. Since 1900 glass factories have been projected in Wrashington. Kansas, Tenuessee, and South Carolina.

Pennsylrania has occupied first place as a glassproducing state for the last three decades. The discovery of gas in Indiana attracted many factories early in the last decade, especially from Ohio, where the gas was practically exhausted for factory purposes after a few years' existence. As a result. in 1900 Indiana has changed places with Ohio as a glass-producing state. the value of its product in 1900 being nearly fire times that of 1890 . New Jerser, the third state in 1900 and 1890 , and the second in 1880 , has held its prominent position by rirtue of good sand deposits and adrantageous geographical position, and largely from the fact that there are numerous native glass workers in the state not at all inclined to leare. eren when better positions are offered elsewhere. There are indications, howerer, that this reserre on the part of the New Jersey workman is disappearing, and it is a question if the state will continue to hold its present position. West Virginia. which was ninth in glass manufacture in 1890 , was seventh in the value of its glass products in 1900 . increasing nearly 100 per cent duriug the decade. The excellent fuel resources of this state, in riew of the rapid decline of the gas fields of Indiana, have recently greatly stimulated the growth of its glass manufacture. and will no doubt have the effect of placing it among the leading states in the industry.

The direction of the growth of the industry has 
always closely followed the fuel supply. The evident failing of the gas supply in Indiana lats fixed attention on the gas field of southeastern Kansas, and it is probable that in a short time the industry will be established in that section, although unfavorable freight rates and the refusal of the eitizens to hold out tempting eash bonuses for the location of factorics have so far kept the glass faetory ont of that field. Some establishments now in Indiana are likely to be soon moved to the gas fields of West Virginia or western Pennsylramia, and some have already been transferred into the coal fields of Indiana and Illinois and will operate with gas produced from the coal of these states. The largest factories in the Indiana gas field are likely to be soon equipped to operate with gas produeed from coal, which will give the glass industry of the state a permanency always lacking when eheap natural gas is the fuel used. During the present decade, owing to the absence of a great cheap fuel supply and the steady adoption of the producer gas-fuel system, many factories will he located at new points within convenient access to the great glass consuming sections, particularly in the West. The Pacific coast is attracting more and more attention as a field for glass manufaeture, and the cheap fuel oil of southern California, eoupled with the growing demand for a glass package from the fruit packers, will probably lead to a decided increase in the glass production of that state within a rery short time.

\section{BUILDING GLASS.}

Table 7 presents comparative statistics, by states, for the building glass industry, for 1890 and 1900.

TABLE 7.-COMPARATIVE STATISTICS, BUILDING GLASS: 1890 AND 1900.

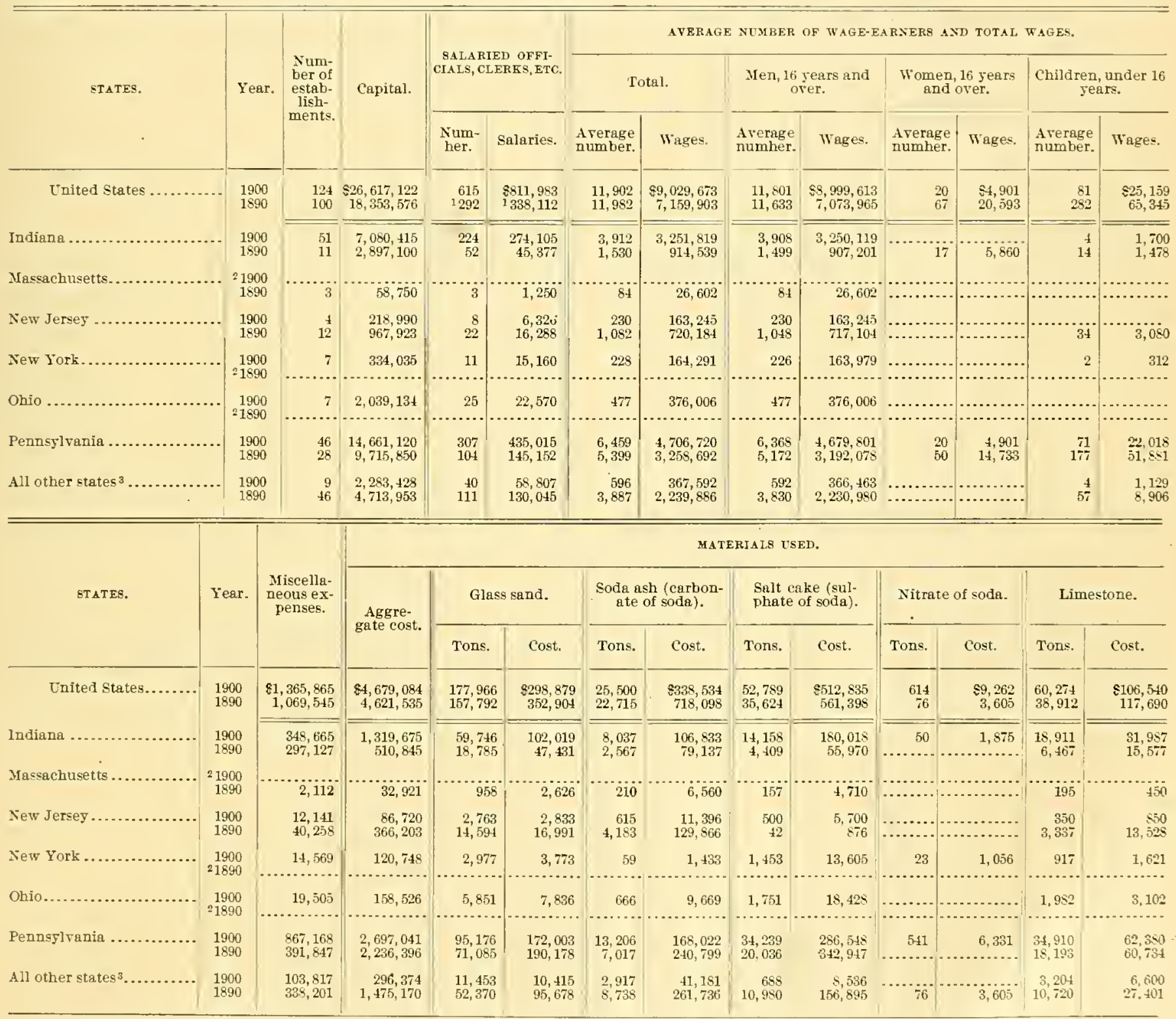

1 Includes proprietors and firm members, with their salarics; number only reported in 1900 hut not included in this tahle. (See Tahle 13 .

2 Included in "all other states."

${ }^{2}$ Includes establishments distributed as follows: 1900-lllinois, 1: Maryland, 2: Massachusetts, 1: Missouri. 2; West Yirginia, 2; and Delaware, 1. 1890-Plate glass: Illinois, 2; Missouri, 2; New York, 1; and Ohio, 1. 1890-Window glass: Delaware, 1; Illinois, 3; Maryland, 4; Massachusetts, 1; . Uichigan, 1; 3rissouri. 1:
New York, 8; and Ohio, 21. 
TABLE 7.COAPARATIVE STATISTICS, BLILDING GLASS: 1890 AND 1900-Continued.

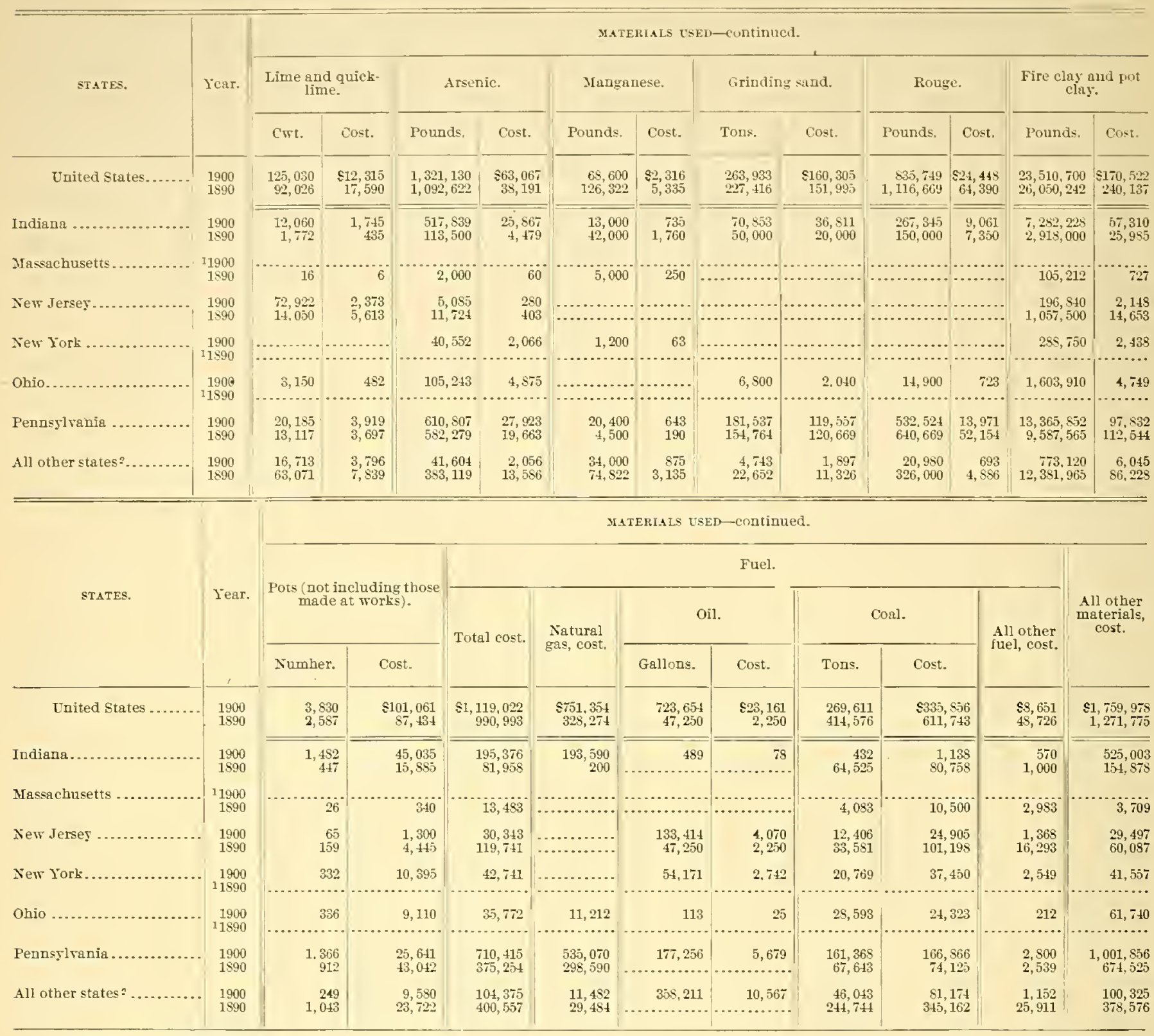

1 Included in "all other states."

Includes establishments distrihuted as follows: 1900-Illinois, 1; Maryland, 2; Messachusetts, 1; Missouri. 2; West Virginia, 2; and Delaware, 1. 1890-Plate glass: Illinois, 2; Missouri, 2; New York, 1; and Ohio, 1. 1590-Window glass: Delaware, 1; Illinois, 3; Mfaryland, 4; Massachusetts, 1; Michigan, 1; Missouri. 1; New York S: and Ohio 21. 
TABLE T.-COIPARATIVE STATISTICS, BUILDING GLASS: 1890 AND 1900-Continued.

\begin{tabular}{|c|c|c|c|c|c|c|c|c|c|c|c|c|}
\hline \multirow{5}{*}{ STATES. } & \multirow{5}{*}{ lear. } & \multicolumn{11}{|c|}{ PRODUCTS. } \\
\hline & & & & & & Bui & ding glass & & & & & \\
\hline & & \multirow{3}{*}{$\begin{array}{c}\text { Total } \\
\text { value. }{ }^{1}\end{array}$} & \multicolumn{2}{|c|}{ Window. } & \multicolumn{7}{|c|}{ Plate. } & \multirow{3}{*}{$\begin{array}{l}\text { All other } \\
\text { produrets, } \\
\text { value. }\end{array}$} \\
\hline & & & \multirow{2}{*}{ Boxes. } & \multirow{2}{*}{ Value. } & Total cast. & \multicolumn{2}{|c|}{ Rough, sold. } & \multicolumn{2}{|c|}{ Polished plate made. } & \multicolumn{2}{|c|}{ Cathedral. } & \\
\hline & & & & & Square feet. & Squarefeet. & Value. & Square feet. & Value. & Squarefeet. & Value. & \\
\hline United State & $\begin{array}{l}1900 \\
1990\end{array}$ & $\begin{array}{r}\$ 17,096,234 \\
13,928,296\end{array}$ & $\begin{array}{l}4,311,282 \\
3,765,884\end{array}$ & $\begin{array}{r}\$ 10,879,355 \\
9,037,187\end{array}$ & $\begin{array}{r}34,758,994 \\
219,319,509\end{array}$ & $\begin{array}{r}628,684 \\
3,106,831\end{array}$ & $\begin{array}{l}\$ 75,887 \\
337,057\end{array}$ & $\begin{array}{c}16,883,578 \\
9,100,111\end{array}$ & $\begin{array}{r}85,158,598 \\
4,172,484\end{array}$ & $\begin{array}{l}8,846,361 \\
2,773,824\end{array}$ & $\begin{array}{l}\$ 567,252 \\
279,407\end{array}$ & $\begin{array}{l}\$ 11 \overline{1}, 142 \\
102,161\end{array}$ \\
\hline Indiana & $\begin{array}{l}1900 \\
1590\end{array}$ & $\begin{array}{l}5,711,948 \\
1, \$ 31,745\end{array}$ & $\begin{array}{r}1,701,729 \\
360,114\end{array}$ & $\begin{array}{r}4,176,5 \$ 7 \\
555,745\end{array}$ & $\begin{array}{l}8,553,938 \\
2,383,793\end{array}$ & $\begin{array}{r}31,917 \\
100,000\end{array}$ & $\begin{array}{r}4,780 \\
20,000\end{array}$ & $\begin{array}{l}5,17 \pi, 160 \\
1,758,248\end{array}$ & $\begin{array}{r}1,415,224 \\
886,000\end{array}$ & & & $\begin{array}{l}15,000 \\
40,000\end{array}$ \\
\hline Massachusetts ... & $\begin{array}{l}{ }^{3} 1900 \\
1890\end{array}$ & $\because 2.79$ & & & $569,370^{\circ}$ & 431,150 & 59,025 & & & & & 13,72 \\
\hline New Jersey. . & $\begin{array}{l}1900 \\
1590\end{array}$ & $\begin{array}{r}274,011 \\
1,316,170\end{array}$ & $\begin{array}{l}124,541 \\
622,432\end{array}$ & $\begin{array}{r}267,611 \\
1,295,100\end{array}$ & & & & $\therefore$ & & & & $\begin{array}{r}6,40: \\
21,0 \pi 0\end{array}$ \\
\hline New York .... & $\begin{array}{r}1900 \\
31890\end{array}$ & 346,790 & $\$ 9,522$ & 243,085 & & & & & & & & $5 \bar{\imath}, 011$ \\
\hline Ohio.... & $\begin{array}{r}1900 \\
31990\end{array}$ & 671,422 & 200,854 & 519,187 & & & & & & & & \\
\hline Penusrltania . & $\begin{array}{l}1900 \\
1590\end{array}$ & $\begin{array}{l}9,213,545 \\
6,106,924\end{array}$ & $\begin{array}{l}2,068,340 \\
1,430,455\end{array}$ & $\begin{array}{l}5,301,131 \\
3,648,577\end{array}$ & $\begin{array}{r}19,516,671 \\
9,024,273\end{array}$ & $\begin{array}{l}579,905 \\
515,17\end{array}$ & $\begin{array}{l}68,032 \\
82,232\end{array}$ & $\begin{array}{r}10,877,250 \\
5,819,519\end{array}$ & $\begin{array}{l}3,441,731 \\
2,676,115\end{array}$ & & & $\begin{array}{l}331,645 \\
. .2 \ldots . . .\end{array}$ \\
\hline All other states ${ }^{4}$. & $\begin{array}{l}1900 \\
1890\end{array}$ & $\begin{array}{r}878,518 \\
4,300,709\end{array}$ & $\begin{array}{r}156,296 \\
1,355,853\end{array}$ & $\begin{array}{r}371,754 \\
3,207,765\end{array}$ & $\begin{array}{l}6,658,482 \\
7,342,065\end{array}$ & $\begin{array}{r}16,862 \\
2,057,504\end{array}$ & $\begin{array}{r}3,075 \\
175,800\end{array}$ & $\begin{array}{r}829,168 \\
1,492,344\end{array}$ & $\begin{array}{l}301,640 \\
610,369\end{array}$ & $\begin{array}{l}8,846,361 \\
2,773,824\end{array}$ & $\begin{array}{l}567,252 \\
279,407\end{array}$ & $\begin{array}{r}5,053 \\
27,36\end{array}$ \\
\hline
\end{tabular}

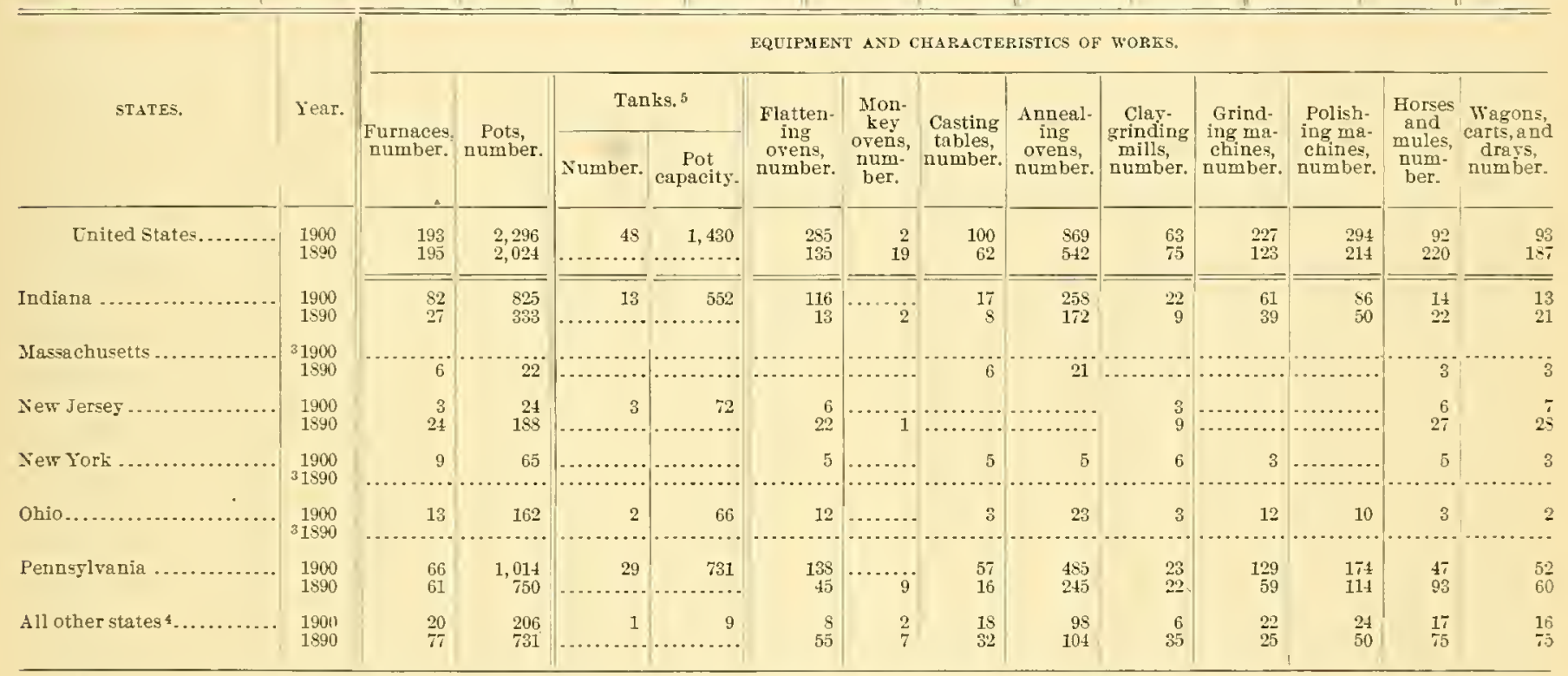

1 While the total value for the respective states is the total value of products reported for all classes of the building glass manufacture, this total can not be obtained by adding the amounts given, as the reports of certain products have been suppressed to avoid disclosing the operations of indiridual establishments.

? Includes $4,338,7+3$ square feet of skylight, ribbed glass, opalescent glass, etc.

"Included in "all other states." glass: Illinois, 2; Missouri. 2; New York, 1; and Ohio, 1. 1890-Window glass: Delaware, 1; Illinois, 3; Marylaud, 4; Massachusetts, 1; Michigan, 1 ; Missouri, i; ew Yorb, 8; and Ohio, 21 
Of the 124 establishments reporting for 1900,13 manufaeture polished plate glass. 9 of which also make skylight; 11, rough. rolled, or ribbed glass, cathedral, wire, or skylight glass, or glass tiling and no platc glass; and 100. window glass.

Plate Glass. - The plate-glass establishments are loeated as follows, by states: 8 in Pennsylvania: 3 in Indiana; and 1 each in Missouri and Ohio. The total capacity of these plants is 53 furnaces with 1,100 pots, haring an estimated eapacity of $31,866,000$ square feet a year. However, only 696 pots were aetive during the census year, easting $21.172,129$ square feet of glass, $16,883,578$ square feet of which were polished, and $628,68 \pm$ square feet sold as rough glass. In $1900,85.5$ per eent more polished plate glass was made than in 1890 , while the prices at whieh it sold were 33.3 per eent under those of 1890 . In 1876 , three years after the first substantial success in the manufacture of polished plate glass in the United States, the domestic production was about 600,000 square feet, and importations for eonsumption were $4,628,439$ square feet, indicating a total plate-glass eonsumption in the United States of $5,228,439$ square feet, against sales of foreign and domestic glass in 1900 of about $18,000,000$ square feet, the imports of plate glass for eonsumption for the year amounting to 1,064,079 square feet.

After abortive attempts to sueeessfully manufacture polished plate glass in this country, at Cheshire. Mass., in 1852-53, and at Lenox Furnace, Mass., in 1855-1871, ${ }^{1}$ the first successful produetion of polished plate glass oecurred at the plant at New Albany, Ind., built in 1869 by Capt. J. B. Ford, and operated after 1872 by W. C. DePauw. Not until 1873 did the plant succeed in producing polished plate glass, and $\mathrm{Mr}$. De Pauw stated ${ }^{2}$ that not until 1879 was it possible to produee the glass at a profit. This plant was dismantled at some time during the last decade because of unfavorable loeation and obsolete equipment. The manufaeture of polished plate glass was eommenced at Crystal City, Mo., in 1875, by the American Plate Glass Company, which company was reorganized the following year by the Hon. E. A. Hiteheoek as the Crystal City Plate Glass Company, and has continued in suceessful operation since, the plant now being owned by the Pittsburg Plate Glass Company, which owned 10 of the 12 establishments reported in 1900 . When Captain Ford left New Albany in $1872,{ }^{3}$ he at once loeated a plant at Louisville, Ky., leaving there in 1875, and starting a plant at Jeffersonville, Ind. These 4 establishments were the ones reported at the eensus of 1880 .

The large profits made by these establishments caused a boom in plate glass factory erection, which was further stimulated by the discovery of gas in Indiana about 1890 ,

${ }^{1}$ Tenth Census of the Onited States, Report on Glass Manufacture; by Joseph D. Weeks, Special Agent, page 98.

Ibid., page 99.

Ibid., page 99 . the suceess of natural gas in the manufacture of plate glass haring been demonstrated in the factor'y built by Captain Ford at Crcighton, Pa., in 1883. In 1893 Hon. E. A. Hiteheock stated before the Ways and Means Committee of the House of Representatives that there were 12 establishments manufaeturing polished plate glass, located at Creighton, Tarentum. Charleroi, Ford City, Butler, Duquesne, and Irwin, in. Pennsylvania; New Albany, Elwood, Kokomo, and Alexandria, in Indiana; and Crystal City, Mo. These establishments manufacs tured plate glass largely in excess of the consumption, and a pcriod of low priees followed, that led, in 1895, to the consolidation of eight establishments under the head of the Pittsburg Plate Glass Company. The outside establishments were the DePanr. at New Albany, Ind.; the American, at Alexandria, Ind.; the Standard Plate Glass Company, at Butler, Pa.; and the Penn Plate Glass Company, at Irwin, $\mathrm{Pa}$. The plant at New Albany was soon abandoned and that at Alexandria was closed, but on the burning of the factory at Irwin about two years ago, the Penn Plate Glass Company secured the factory at Alexandria, Ind., and now operates it as the American Plate Glass Company.

In 1897 the Marsh Plate Glass Company erected a plant at Walton (now Floreffe), Pa., to manufacture thin plate glass under the patents of George Marsh, whieh substituted a table for holding the plate by a vaeuum process in place of plaster of paris, during the grinding and polishing. The Marsh Company claimed to be able to successfully manufaeture polished plate glass in all popular glazing sizes as thin as one-sixteenth of an ineh, and by their improved table and system of holding the glass, to practically eliminate all breakage. Before this clain was fully demonstrated, the plant was bought by the Pittsburg Plate Glass Company, and has sinee been used largely as an experimental faetory. Experiments in the manufaeture of thin plate glass are also being tried at the plant of the Pittsburg Company at Ford City, Pa. The Marsh Company was the first to successfully introduee the continuous lehr for annealing plate glass, a proeess that promises to soon displace the slower and more expensive annealing kiln system. A faetory was ereeted near Toledo, Ohio, by the Edward Ford Plate Glass Company in 1900, which was in operation only six months during the census year. This faetory is equipped with a eontinuous lehr, and in the extensive use of electrieity as motive power is an innoration.

The principal improrement in plate glass manufacture during the last decade was undoubtedly the suecessful introduetion of the annealing lehr, as noted above, at the plant of the Marsh Plate Glass Company, at Walton, $\mathrm{Pa}$. Although its introduction into the older plants has so far been slow, owing to the expense attending the abandonment of the costly kiln srstem in use at those plants, yet competition will soon have the effect of bringing the lehr into general use. Previous to the introduction of the lehr, the annealing 
of plate glass was done in practically the sume manner as at the commencement of the induntry in this country. Is soon as the cast is made the plate is introduced into the annealing oven or kiln. a large. shallow, reverberator furnace of brick, on the smooth floor of which the plate is laid. The kiln being heated to near the melting point and all openings tightly closed, it is allowed to cool gradually to a point where it is opened and the plate remored, the process requiring fully three days.

The plate glass annealing lehr averages about 200 feet in length, and starts from the casting table as a continuous. connected series of five kilns, after which it is the usual rod lehr common in window glass manufacture. The fire stations at the start are on a solid hearth of especially prepared clar. giving an absolutely smooth, lerel bed. The whole interior of the lehr is brilliantly lighted br eleetricity. and the heat at any point can be controlled with the utmost nicety by the use of prrometers. After the cast is made the plate is introduced into the first station of the lebr, where the temperature is near the melting point. In due time the plate passes into the second station, where the temperature is lower. So the plate passes through the five stations with a diminishing temperature. When the plate leares the fifth station. it has become tholoughly " set," and passes to the rod lehr. which arries it along through decreasing temperatures until. three hours after the cast was made. the annealing process is conplete, and the plate is taken out of the lehr ready for the grinding process. The time required to anneal a plate under the lehr system. compared with that under the kiln system-three hours as against three days-indicates the revolutionizing possibilities of the lehr, when cost of construction is also taken into consideration. A lehr that will anneal the product of 16 pots, or 16 plates of glass a day, costs about $\$ 20.940$ to build, and displaces 96 old-style thrceplate kilns. which cost about $\$ 1,000$ each to build. The lehr takes up far less space than does the kiln system, and the building required for the lehr costs about $\$ 6,000$, as against $\$ 30.000$ for the construction of the proper building for the 96 kilns it rould displace.

With the lehr, smaller pots are used and thinner and smaller plates cast. resulting in a great increase in the arelage size of the finished plate, as the smaller the original cast. the better are the chances for the plate going through the annealing, grinding, and polishing processes successfully without diminution of size. The lehr-annealed plate, is much straighter than that annealed in the kiln, owing to the solid hearth of the first fire stations of the lehr: the floor of the kiln is muen more liable to derelop inequalities which misshape the plate. The thinness of the lehr-annealed plate means less time spent in grinding. and the smaller size of the rough plate, makes it possible to lay and relay the lehrannealed plate on the grinding and polishing tables, much quicker', and with less labor', than the kiln-annealed plate.

o. $228-2$
11. L. Dixon. the well-known glass furnace enuineer. asserts that so per cent of the polished plate glass manufactured can be annealed in the lehr. the remaining 10 per cent being glass in extremely large sizes. requiring the old style kiln. He is convinced that it is only a question of time until the rer. largest sizes can be annealed in the lehr. It is clained that actual practice has shown that the arerage size of the lehr-annealed glass, cast from small pots, is 90 square feet per plate when squared, while under the kiln system. with large pots and the attempt to continually cast extreme sizes. the average size of the plate taken from the kiln and squared is about 60 square feet, and when finished, about 18 square feet. In addition to the lehr at Floreffe, $\mathrm{Pa}$. the Pittsburg Plate Glass Company reported 3 lehrs at Ford City, Pa., 2 of the 3 being for large sizes and the third for small sizes of about 50 to 60 square feet. The Ford Plate Glass Company. near Toledo, Ohio. report 1 lehr that is said to operate successfully on sizes of 50 to 60 square feet. At Alexandria. Ind., the Ameriean Plate Glass Company have a lehr which is said to be working satisfactorily with plates from $i 5$ to 80 square feet.

As is often the case with important inrentions, the successful introduction of the lehr in plate glass manufacture came, not from experts. but from novices in the plate glass business, who carried it to success. while the plate glass manufacturers grected it with derision and declared it impossible. Henry Fleckner. a reteran window glass factory manager of Pitsburg. was the man who first operated the lehr with success at Malton. and the successful operation of the lehrs at Ford City and Toledo, is said to be largely due to Eugene Morenus, a window glass factory manager, and Ralph Grar. a manufacturer of skylight glass.

In addition to the lehr. the Marsh Plate Glass Company at Walton introduced, in the Marsh patent table. the idea of reducing the temperature of the glass rhile being ground and polished, by the circulation of a constant flow of water under the table. This cooling derice, which permits the operation of the grinders and polishers at a much higher speed. has been installed in sereral foreign factories by Mr. Marsh. and will no doubt soon be put into use in this country. The transfer tables introduced at Ford City. Pa.. in the last decade, have added considerably to the rapidity and ease of production, as has also the extended use of electricity as a lifting and motire porrer. Prior to the adoption of the transfer table, the grinding and polishing tables were stationary. and after one side of the plate had been ground and polished, it was necessar? to remore it from its bed of plaster to continue the process. The transfer table is morable from grinder to polisher. thus maling it possible to grind and polish one side of a plate without turning it. effecting a great saving in tine and dccreasing the loss br breakage attending the operation of moring the plate from it: bed of plaster of paris. 
President John Pitcairn. of the Pittsburg Plate Glass Company, testified ${ }^{1}$ before the subcommission of the United States Industrial Commission. at Philadelphia, Pa.. December 22. 1900. that since the inception of the plate glass industry in this country. the tendency of prices bas been downward, except during 1900, when prices were increased. as a result of an arerage increase in the cost of raw materials of ahout 85 per cent, increased cost of manufacture, owing to the diminution of the gas supply, and the substitution of coal, and a better understanding among the manufacturers. He submitted the following table of prices. at periods of five years from 1565 to $1: 100$ :

\begin{tabular}{|c|c|c|c|c|c|c|}
\hline SQLARE FEET. & 1575 & 15611 & $14 \times 5$ & $15: 30$ & 1595 & 1900 \\
\hline $\begin{array}{l}1 \text { to } 3 \ldots \ldots \ldots \\
3 \text { to } 5 \ldots \ldots \ldots \\
5 \text { to } 10 \ldots \ldots \ldots \\
10 \text { to } 25 \ldots \ldots \ldots \\
25 \text { to } 50 \ldots \ldots \ldots \\
50 \text { to } 100 \ldots \ldots \ldots\end{array}$ & $\begin{array}{r}50.71 \\
0.84 \\
1.12 \\
1.49 \\
1.56 \\
1.69\end{array}$ & $\begin{array}{r}80.51 \\
0.61 \\
0.80 \\
1.06 \\
1.11 \\
1.21\end{array}$ & $\begin{array}{r}\$ 0.46 \\
0.55 \\
0.72 \\
0.96 \\
1.01 \\
1.09\end{array}$ & $\begin{array}{r}80.40 \\
0.49 \\
0.61 \\
0.85 \\
0.89 \\
0.97\end{array}$ & $\begin{array}{l}80.30 \\
0.36 \\
0.48 \\
0.63 \\
0.66 \\
0.72\end{array}$ & $\begin{array}{l}90.31 \\
0.38 \\
0.60 \\
0.81 \\
0.85 \\
0.90\end{array}$ \\
\hline
\end{tabular}

During 1897. overproduction resulted in a demoralized condition of the industry and prices were very low. The advance in prices from that time to 1900 was cstimated by Mr. Pitcairn to anount to from 50 to 60 per cent. According to the same authority, about twothirds of the American plate-glass production is sold in sizes under 10 square feet and without profit, a very large part of this two-thirds being sold at a loss. This glass comes into competition with the imported German looking-glass plate. which is blown, ground, and polished, and imported largely into this country to be silvered and used in cheap mirrors. For several years the American plate-glass manufacturers havc been meeting this glass. and by a special arrangement with the manufacturers of furniture and mirrors. have succeeded in displacing it with domestic plate glass of a better quality at prices less than the cost of production. Since 1895 the bulk of the American polished plate glass has been sold direct to the consumer, the Pittsburg Plate Glass Company haring established jobbing houses in nearly a score of the large cities. in which branch of the business $\$ 4,04.000$ was invested in 1900 .

For year's and with but slightinterruptions, the plateglass manufacturing interests of Europe have been closely allied as to regulation of prices and adjustment of production. As the business of the plate-glass industry in the Inited States has never been extended beyond the home market. cooperation on that account has not been considered raluable by the European interests; hence, this market has been a "dumping gr"ound" for the surplus European production. and exceptionally low prices have been made on foreign glass for the United States. During the census year prices on stock sizes of European polished plate glass were 36 per cent lower for the United States than for England. while

\footnotetext{
${ }^{1}$ Report of the Industrial Commission, Vol. IIII, Trusts and Industrial Combinations, pages 225 to 242.
}

polished plate glass imported into the United States from France. arclaged only about 50 per cent of the prices quoted in that comntry. The fact that the European surphs is placed in this market at a price below arerage cost. accounts for the heary importations of polished plate glass. In fiace of this the domestic production in 1900 increased 85.5 per cent over that of 1890 , evincing the steady acquisition of the home market for the domestic product. The production of polished plate glass in Europe in 1900 was given by Mr. Pitcairn in his testimony, in the following table, which shows the regulation of production by giving the productive capacity. and the actual output of the sereral factories:

\begin{tabular}{|c|c|c|}
\hline XAMES OF COMPANIES. & $\begin{array}{l}\text { Producing } \\
\text { capacity, } \\
\text { square feet. }\end{array}$ & $\begin{array}{l}\text { Actual out- } \\
\text { put } \\
\text { square feet. }\end{array}$ \\
\hline 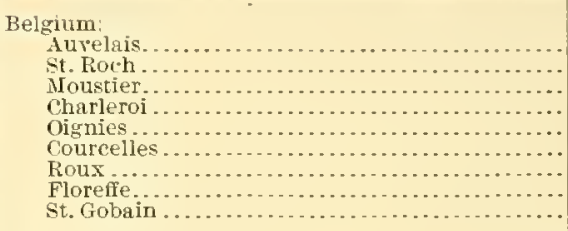 & $\begin{array}{r}5,000,000 \\
5,000,000 \\
3,300,000 \\
2,900,000 \\
2,200,000 \\
2,100,000 \\
1,900,000 \\
1,500,000 \\
800,000\end{array}$ & $\begin{array}{r}2,500,000 \\
2,500,000 \\
1,600,000 \\
1,400,000 \\
1,100,000 \\
1,100,000 \\
1,100,000 \\
700,000 \\
400,000\end{array}$ \\
\hline Total, 9 factories... & $24,700,000$ & $12,400,000$ \\
\hline 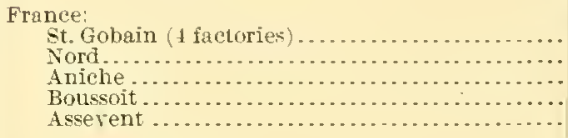 & $\begin{array}{l}7,500,000 \\
3,700,000 \\
1,700,000 \\
1,600,000 \\
800,000\end{array}$ & $\begin{array}{r}3,800,000 \\
1,800,000 \\
1,400,000 \\
\quad 800,000\end{array}$ \\
\hline Total, s factories..... & $15,300,000$ & $7.800,000$ \\
\hline 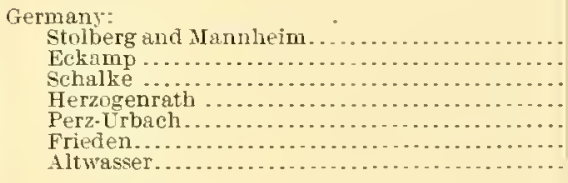 & $\begin{array}{l}4,700,000 \\
2,600,000 \\
2,000,000 \\
1,900,000 \\
1,600,000 \\
1,200,000 \\
700,000\end{array}$ & $\begin{array}{r}2,400,000 \\
1,300,000 \\
1,000,000 \\
1,000,000 \\
600,000 \\
300,000\end{array}$ \\
\hline Total, 8 factories ........ . . & $14,700,000$ & $6,600,000$ \\
\hline 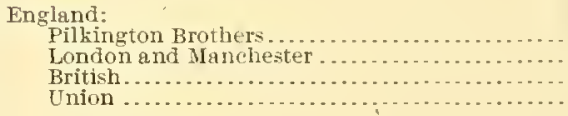 & (n. & $\begin{array}{r}4,200,000 \\
2,300,000 \\
900,000 \\
500,000\end{array}$ \\
\hline Total, 4 factories. & ${ }^{1} \overline{7}, 900,000$ & $7,900,000$ \\
\hline 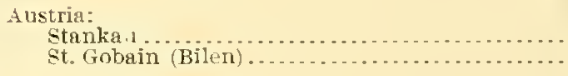 & & \\
\hline Total, 2 fretories. & ${ }^{1} 2,300,000$ & $1,100,000$ \\
\hline 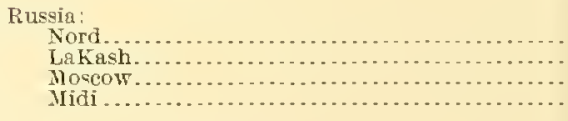 & (n..... & $\begin{array}{r}1,100,000 \\
700,000 \\
700,000 \\
700,000\end{array}$ \\
\hline Total, 4 factories . .......................... & $13,200,000$ & $3,200,000$ \\
\hline $\begin{array}{l}\text { Italy: } \\
\quad \text { Pisa (St. Gobrin Company) .... }\end{array}$ & 800,000 & 800,000 \\
\hline Grand total... & $68,900,000$ & $39,800,000$ \\
\hline
\end{tabular}

1 Produeing eapacity of each factory not reported separately.

The arerage wages paid in plate glass manufacture in the United States, during the year 1900 , was estimated by Mr. Pitcairn to be about 200 per cent higher than in England, and about 300 per cent higher than in Belgium. In support of the latter claim he presented the following table, giving a comparison of American and 
Belgian wages in the plate glass industry in 1900 , the Belgian figures being compiled by the European representative of the Pittshurg Plate Glass Company:

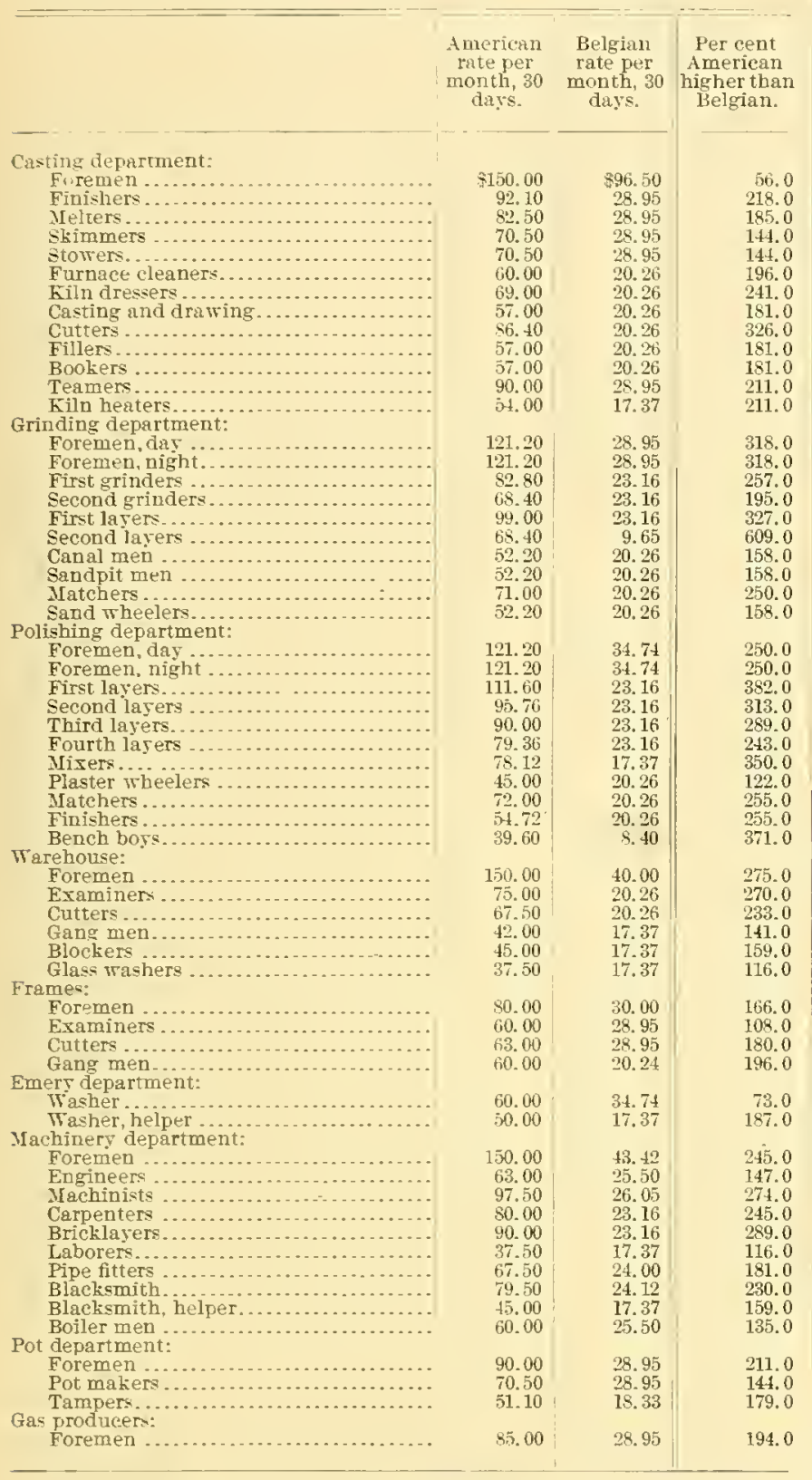

About 66 per cent of the wage-earners in the plateglass industre are native Americans. At the commencement of the industry in the United States it was necessary to get foreign workmen of experience. but the American is so much quicker to learn and is so much more steady, that he is preferred at present.

All of the improvement made in the manufacture of plate glass in this country during the last twenty-fice rears: aside from some details in the construction of inachinery, has been for the purpose of increasing the size of the plates cast and improving the quality of the glass. Until very recently the same methods have been employed for casting. annealing, grinding, and polishing that have been in use for rears. The liability of breakage during the finishing jrocess that has attended the attcmpts to cast extremely largr-sized plates. has resulted in a very great raduction in the arerage size of finished plates. The use of smallel pots. cascing smaller and thinner plates tor annealing in lehrs. and the adoption of new machinery for grinding and polishing, will undoubtedly lesult in a considerable decrease in the rost per square foot, and an inclease in arelage size of tinished platcs, along with a material decrease in undesirable small sizes. A few large pots will be sufficient to supply the demand for extremely large sizes. In the manufacture of plate glass. the use of tank melting furnaces in connection with fining-pot furnaces, is likely to appear in the near future. and the size of the plates cast can then be regulated at will. The possibilities of such a process in connection with the continuous lehr, can scarcely be estimated. The introduction of the continuous lehr, has largely reduced the high ratio formerly existing between cost of construction and capacity of plate-glass factories. and has already resulted in the entrance of 6 new companies. into the field: 4 of the projected factories being in Pennsylvania, and 1 each in Michigan and Illinois.

Cathedral Glas. - There wère $8.8+6.361$ square feet of cathedral glass manufactured in 1900. ralued at $\$ 567,252$. compared with 2.773 .824 square feet in 1890 . valued at $\$ 279.407$, an increase in quantity of 215.9 per cent, and in valuc of $10 \%$ per cent. The qualit 5 of this product lias been brought to such perfection, that not only has the domestic market been largely supplied. but a good export trade has been dereloped with Germany. England, and Fiance. The superiority of colors is increasing the demand for American cathedral or opalescent glass, from the leading foreign alt centers. During the census year, $t$ establishments in New Iork. Indiana, and Illinois reported export shipments direct from factories to the value of $\$ 13,43$ \%

Wire Glass. - The manufacture of wire glass bas been established in the United States on a firm basis during the last decade. and it is probable that this branch of the building glass industry will reach large proportions in the next few years. The quantity manufactured during the consus year was $1,295,504$ square feet, ralued at $\$ 129,051$. During the year sereral shipments were made to England, but exact details could not be secured. The industry is yet in its infancy. Wile glass. which is made by casting two sheets of glass with a wire net imbedded between them, has been recognized as a perfect fire retardent, especially adapted for partitions. firc shutters, skylights, and glazing in all places subject to the stress of fire or storm. It is manufactured br $t$ establishments, 3 in Pennsylrania and 1 in Missouri.

Skylight Gilas. ete. - Although no statistics of skrlight glass are shown in the report on glass manufacture at the Elerenth Census, it can be stated that the manufacturc of this product has considerably increased. reaching 3.679.4i9t square teet. ralued at \$165.086. in 1900. 
Nearly all the plate-glass establishments make a specialty of its manufacture and : separate establishments produce it almost exclusively. The export trade in this glass is dereloping in an encouraging manner. The production of bent glass. for store fronts. show cases, etc. is becoming a prominent feature in connection with the production of plate glass, and there are several establishments, in addition, exclusively engaged in this business, which obtain the plate and window glass sheets from the factories and rework them, so are not included in this report. Of the 9 bending ovens included in this report, 5 are in Indiana and $t$ in Pennsylrania. Within a few years the manufaeture of glass tile has been introduced in this country on an extensive scale. One establishment is making it exclusively, while several others report it as a side line. Its use as a perfect sanitary wall, ceiling, and floor material gives promise of a large growth in this branch of glass manufacture.

Window Glass.-During the last decade a rery great improvement has been made in the manufacture of window glass in the United States. This has been brought about by the introduction of the continuous tank furnace for melting the erude materials, in preference to the pot furnace which had been used exclusively since the start of the industry in this country in the early colonial days. Separate statistics of tank furnaces are not shown in the report on glass manufacture at the census of 1890 , the tank prior to that date being largely an experiment in this country and in such limited use as to be deemed unworthy of special note at that census. At that time, however, the tank furnace was in snceessful use in Europe, especially in Belgium. The successful introduction of the tank furnace in the United States occurred at Jeannette, Pa., in 1SsS. and from 1890 it has been steadily displacing the pot furnace, until in $1900,54.5$ per cent of the capacity of active window-glass factories was contained in tank furnaces. The adoption of the tank has given the window-glass industry a permanency that was lacking when pot furnaces were used exclusively, and when the cost of construction was not great enough to prevent the ready abandonment of a plant for a more avantageous location. While the tank melting system is much more economical than the pot-furnace system, the cost of installation and other factory equipment is much greater. As a result the location of the tank factors is mgre apt to be selected with respect to permanencr than is the case with the pot-furnace factory. The operation of tank furnaces by gas produced from coal has proven very satisfactory, both as to the quality of glass produced and cheapness of cost, indieating, in view of the failing supply of natural gas, the fuel likely soon to be in most general use.

The census year covered a portion of a period of great activity in window glass finctory construction on a large and permanent scale. an activity possibly the greatest in the history of the industry. For several years prior to 1900 the establishments operating the largest proportion of the capacity lad been getting into closer relations as to regulation of prices and factory operation, resulting in the more or less constant maintenance of an exeeptionally good price list. These high prices attracted new capital into the field, and during the census year there were over 30 factorics reported which were built within two years. At the close of the census year about 30 window-glass factories were either building or definitely planned, notwithstanding the fact that during the rear a elose combination of establishments, eontrolling about 65 per cent of the total eapacity, had becn effected and prices had been sharply cut to discourage further erection of factories.

In 1900 there were 100 establishments reported as manufacturing window glass, an increase of 19 per eent over the number reported in 1590, and 104.1 per eent over the number reported in 1880 . Only 19 more melting furnaces were reported in 1900 than were reported in 1890, but, owing to the greater capacity of the tank, the gain in total pot eapacity was 87 per cent. In 1900 there were 165 melting furnaces reported, with a total capacity of 2,429 pots; 146 furnaces of a total capacity of 1,299 pots in 1890; and 76 furnaces with a capacity of 665 pots in 1850 ; sbowing a gain since then of 117.1 per cent in number of furnaees, and 265.3 per cent in pot capacity. In 1900 the production was $4,341,282$ boxes, valued at $\$ 10, \$ 79,355$; in 1890. $3,768, \$ 84$ boxes, valued at $\$ 9,058, \$ 02$; and in $1880,1,864,734$ boxes, valued at $\$ 5,047,313$. There is indicated an increase of 15.2 per cent for 1900 orer 1890 in the number of boxes produced, and an inerease of 20.1 per cent in the total value of products. Compared with 18s0, the number of boxes produced in 1900 increased 132.8 per cent, and the total ralue of product increased 115.5 per cent. The average value of a box of window glass ( 50 square feet), aceording to the census returns in 1900 was \$2.51: in 1590 . \$2.40: and in $1880, \$ 2 . \% 1$.

Of the 165 furnaces with a total capacity of 2,429 pots reported in 1900, 36 were tank furnaces of a total capacity of 1.327 pots and 129 were pot furnaces that contained 1,102 pots, a deerease from the number of pot furnaces and their total eapaeity as reported in 1890 , of 11.6 per eent and 15.2 per cent, respectively. The great increase in capacity in 1900 over 1590 is confined entirely to the tank furnace, but the total production of 1900 compared with 1890 is not in keeping with this increase. owing to the greatly restricted operation of the factories in 1900, due to a "fire" averaging about six months as against a "fire" of ten months in 1890 .

The distribution of the window glass capaciț of active establishments in furnaces and pot eapacity for 
1900 is shown in the following statement, by states, in the order of their importance in capacity:

\begin{tabular}{|c|c|c|c|c|c|c|c|}
\hline$S T \Delta \tau E S$ & $\begin{array}{l}\text { Num- } \\
\text { ber of } \\
\text { estab- } \\
\text { lish- } \\
\text { ments. }\end{array}$ & $\begin{array}{l}\text { Total } \\
\text { number } \\
\text { of fur- } \\
\text { naces. }\end{array}$ & $\begin{array}{c}\text { Totrl } \\
\text { pot ca- } \\
\text { pacity. }\end{array}$ & $\begin{array}{l}\text { Num- } \\
\text { ber of } \\
\text { tank } \\
\text { fur- } \\
\text { naces. }\end{array}$ & $\begin{array}{l}\text { Pot ca- } \\
\text { pacity: }\end{array}$ & $\begin{array}{l}\text { Num- } \\
\text { ber of } \\
\text { pot fur- } \\
\text { naces. }\end{array}$ & $\begin{array}{l}\text { Num. } \\
\text { ber of } \\
\text { pots. }\end{array}$ \\
\hline [nited States. & 100 & 165 & 2,429 & 36 & 1,327 & 129 & 1,102 \\
\hline Indiana ....... & 46 & $\$ 3$ & 1,109 & 17 & 601 & 66 & 508 \\
\hline Pennsylrania ..... & 32 & 45 & 960 & 14 & 588 & 34 & 372 \\
\hline Ohio $\ldots \ldots \ldots \ldots \ldots$ & 6 & 10 & 128 & 2 & 66 & 8 & 62 \\
\hline New Jersey ........ & 4 & 6 & 96 & 3 & 72 & 3 & 24 \\
\hline New lork & 5 & 5 & & & & 5 & 40 \\
\hline Maryland .......... & 2 & 5 & & & & 5 & 28 \\
\hline West Virginia ..... & 2 & 3 & 22 & & $\ldots$ & 3 & 22 \\
\hline Delaware........... & 1 & 2 & 16 & & & 2 & 16 \\
\hline Massachusetts ...... & 1 & 2 & 18 & & ........ & 2 & 18 \\
\hline Illinois . ........... & 1 & 1 & & & & 1 & 12 \\
\hline
\end{tabular}

The bulk of the capacity of Indiana was in the counties of Grant, Blackford, Madison, Delaware, and Jay, located in the "gas belt." The capacity in Pennsylrania was largels confined to the Pittsburg district and McKean county. The Ohio plants were at Barnesville, Lancaster, Findlay, and Quaker City. The largest proportion of the capacity located in New Jersey was in Cumberland county. In New York there were 5 factories, 3 of which were in Ithaca, and 1 each in Canastota and Durhamville. The 2 factories in Maryland were located in Baltimore. There was 1 factory in Delaware, located at Wilmington. The only plant in Massachusetts, which was originally established in 1853 , was at Berkshire. About 75 per cent of the total capacity was controlled from Pittsburg, Pa., the headquarters of the American Window Glass Company, and about ten other companies. The former owned 39 plants during the census year:

At the close of the census year there was either building or definitely planned ncw capacity amounting to over 600 pots. Over 100 of thesé new pots were located in West Virginia; nearly 250 in the district of McKean county, Pa.; about 75 in the coal fields of Illinois and Indiana; 75 in southern Nerv Jersey; and about 75 in the "gas belt" of Indiana.

One feature of the manufacture during the census year was the notable scarcity of skilled workmen. This scarcit, together with the increase in the capacity of the plants, made the total capacity greatly exceed the supply of skilled workmen available for its operation in the four divisions of the work, gathering, blowing, flattening, and eutting. The supply of workmen was about sufficient to operate 2,000 pots, and owing to the strong organization of the men and their strict rules of admission, no considerable relief was possible. The result was that the skilled workmen dominated the industry as seldom before in the history of the trade. The wage scales were the highest in years, and most profitable inducements were offered in addition by manufacturers to secure men for their plants. Every window-glass factory in the country operates under union rules, and the wage scales are settled for each "fire" at conferences of committees representing the manufactures's and the union.

The 5 companies of a "miscellaneous" charatel' shown in Table 13 were all conperative and engaged in the manufacture of window glass, most of them having been established within the census year; and were financially supported by the union, which loaned money proportioned on the pot capacity of each plant. There were 2 establishments of this character reported in the pressed and blown ware and bottle and jar branch of the industry. It should be stated. in this connection, that there werc in the glass industry in addition incorporated establishments of a cooperative character operating under charters, which in all the tables are included under the head of corporations. They are in all essential particulars cooperative associations. This movement toward cooperation arose from the desile to securc more work during the ycar, the capacity of the factories having been for some time so much in excess of curlent consumption that the "run" of the factories had been getting less each year, averaging about six months where it was formerly ten. The past record of cooperation in the window glass industry of the United States has been unsatisfactory, all going well as long as the market conditions were good, but financial ruin usually appearing with any depression in the trade. The indications at present are very favorable for cooperative manufacturc, and it will probably spread rery rapidly in the industry in the near future. The greatest impetus it reccives comes from the scarcity of workmen, which is leading manufacturers to organize companies in whicl a large share of the stock is-held by the workmen, who are thus less likely to be tempted amay by offers from other manufacturers.

Along with these quasi-cooperative companies many real cooperative companies, composed entirely of the men in the factory, are being established, especially among the Belgian workmen, who form a considerable proportion of the entire working force. The windowglass workers compose the only body of organized workmen in the building-glass manufacturing industry of this country, there being no organization among the plate-glass workers, from whom rery little skill is required, machinery doing practically all the work in the factory.

The question of machinery is beginning to agitate the window-glass industry. So far, practically the entire process of numufacture requires skilled hand labor. The growing scarcity of workmen has stimulated efforts to perfect a mechanical process which will do the work now done by the gatherer and blower, and it is probable that eventually the smaller sizes of window glass will be successfully manufactured by machinerr.

The average nolmal consumption of window glass in the $I^{\top}$ nited States is estimated at $5,400,000$ boxes a rear. A considerable portion of this demand is supplied by imported glass, chiefly from Belgium. This market 
has for years leceired the surplus window gliss of that country. and any advance in American prices at once results in increased importations. The sto-foot box of single strength foreign glass weighs about sixty-two and one-lalf pounds. and the 50-foot hox of double strength. about ninety-two and one-half pounds. In reducing the number of pounds of imported glass to boxes. the arerage weight of $a$ box is placed at 70 pounds. and it is estimated that 25 per cent of the total glass imported is double strength. The total importation of window glass for the year ending June 30,1900 , was 51.343 .339 pounds, or 733,476 boxes, valued at \$1,555.924. There were imported $47,202,267$ pounds in 1899: 38.908 .992 pounds in 1898; 55,961,813 pounds in 1897: $53,182.301$ pounds in 1896: $40,786,279$ pounds in 1895: 52.436 .068 pounds in 1894; $63.715,989$ pounds in 1893: 72.682,127 pounds in 1892: $28.932,738$ pounds in 1891; and 73.112 .550 pounds in 1890 Astrike, which was threatened in the Belgian factories at the close of 1900. caused a sharp decrease in the importation of window glass in 1901. The quantity imported during the year ending June 30, 1:601, wils 27.285 .607 pounds.

The American window glass exported during the real ending June 30. 1900, was ralued at $\$ 36,218$, and in $18: 14$ at $\$ 32.690$. The domestie glass can not compete with the cheaper foreign glass, yet an increasing quantity of American window glass is going into Mexico, Canada. and the TWest Indies.

\section{PRFSSED ANI BLOWN GLASS ANI BOTTLES AND JARS.}

Table s presents comparative statistics. by states, of the manufacture of pressed and blown glassware and bottles and jars. for 1890 and 1900.

\section{TABLE S.-COMPARATIVE STATISTICS, PRESSED AND BLOWY GLASS AND BOTTLES AND JARF, BY STATES: 1890 AND 1900.}

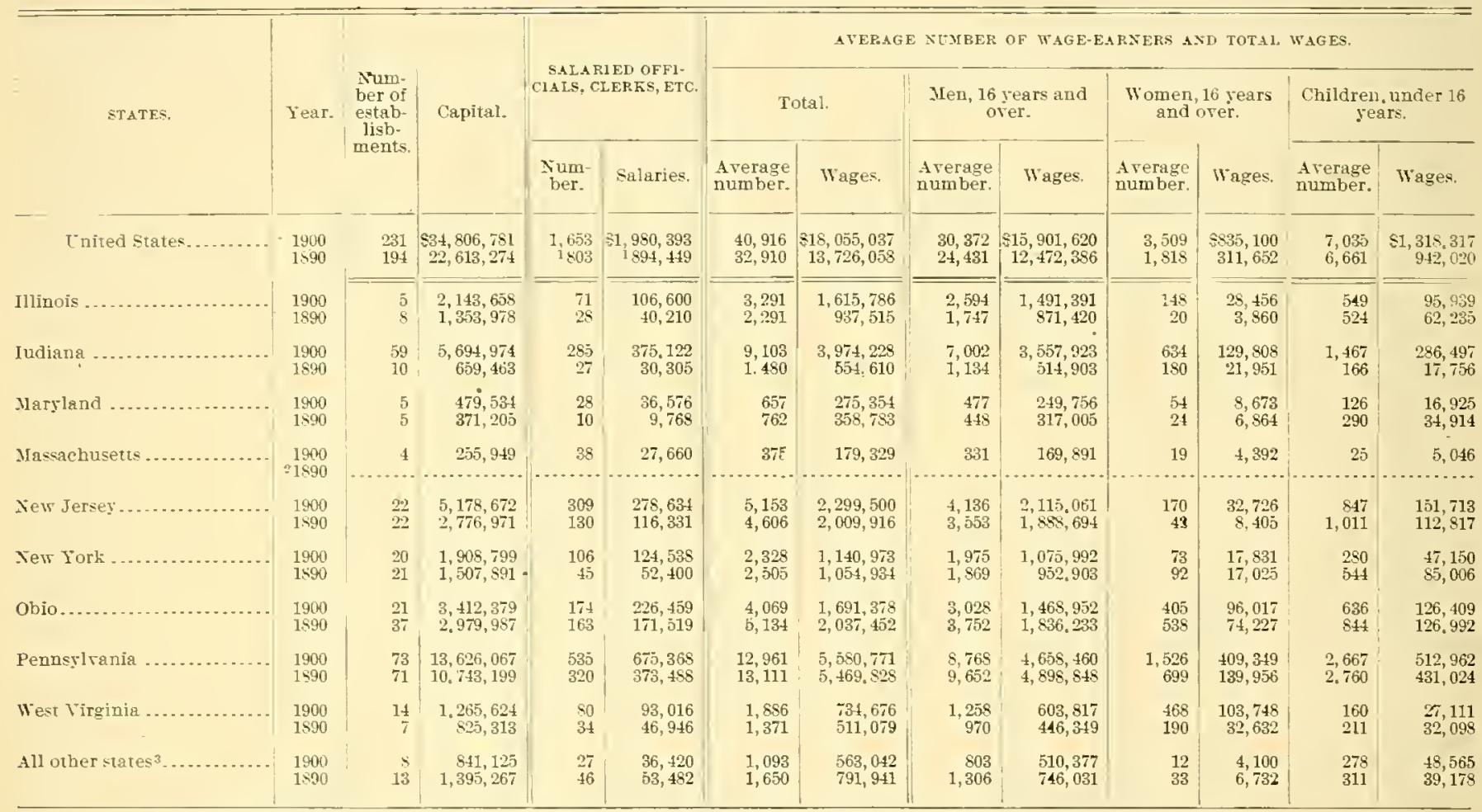

1neludes proprietors and firm members, with their salaries; number onls reported in 1900, but not included in this table. (See Table 14.)

Included in "a other states.

${ }^{3}$ Includes establishments distributed as follows: 1900-California, 1: Colorado, 1; Georgia, 1: Michigan, 1; Missouri, 1; Virginia, 2: Wisconsin, 1. 1890-California, 1; Colorado, 1; Georgia, 2; Kelltueky, 2: Maryland, 2; Massachusetts, 2; Missouri, 2; W'isconsin, 1. 
TABLE S.-COMPARATIVE STATISTICS, PRESSED AND BLOWN GLASS AND BOTTLES AND JARS, BY STATES: 1890 AND 1900-Continued.

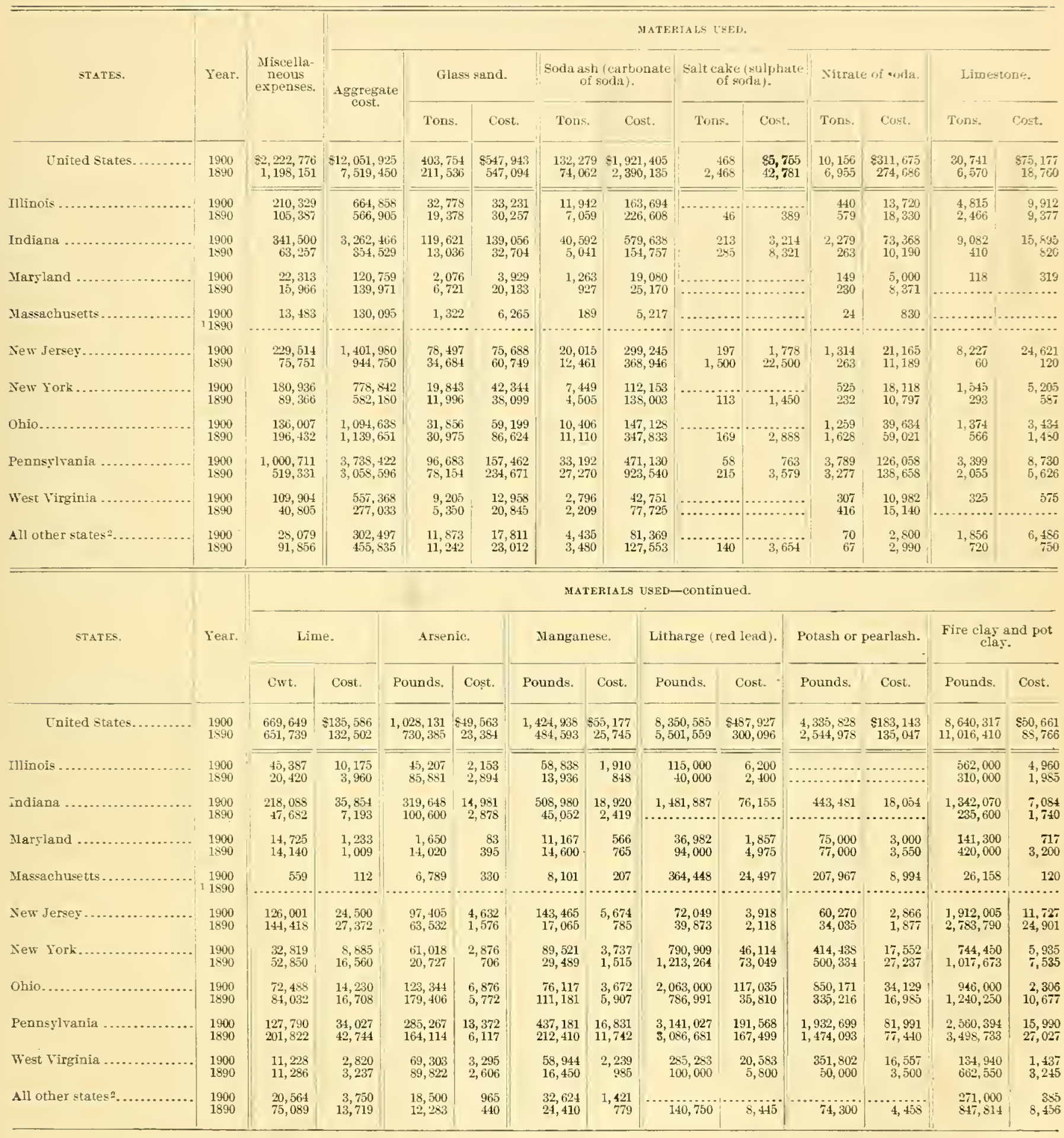

1 Includea in "all other states."

2Includes establishments distributed as follows: 1900-California, 1; Colorado, 1; Georgia, 1; Michigan, 1; Missouri, 1; Virginia, 2; Wisconsin, 1. 1890-Cali. fornia, 1: Colorado, 1; Georgia, 2; Kentucky, 2; Maryland, 2; Massachusetts, 2; Missouri, 2; Wisconsin, 1 . 
TABLE S.-COMPARATIVE STATISTICS, PRESSED IND BLOWX GLASS AND BOTTLEN AND JARS, BY STATLS: 1890 AND $1900-$ Continued.

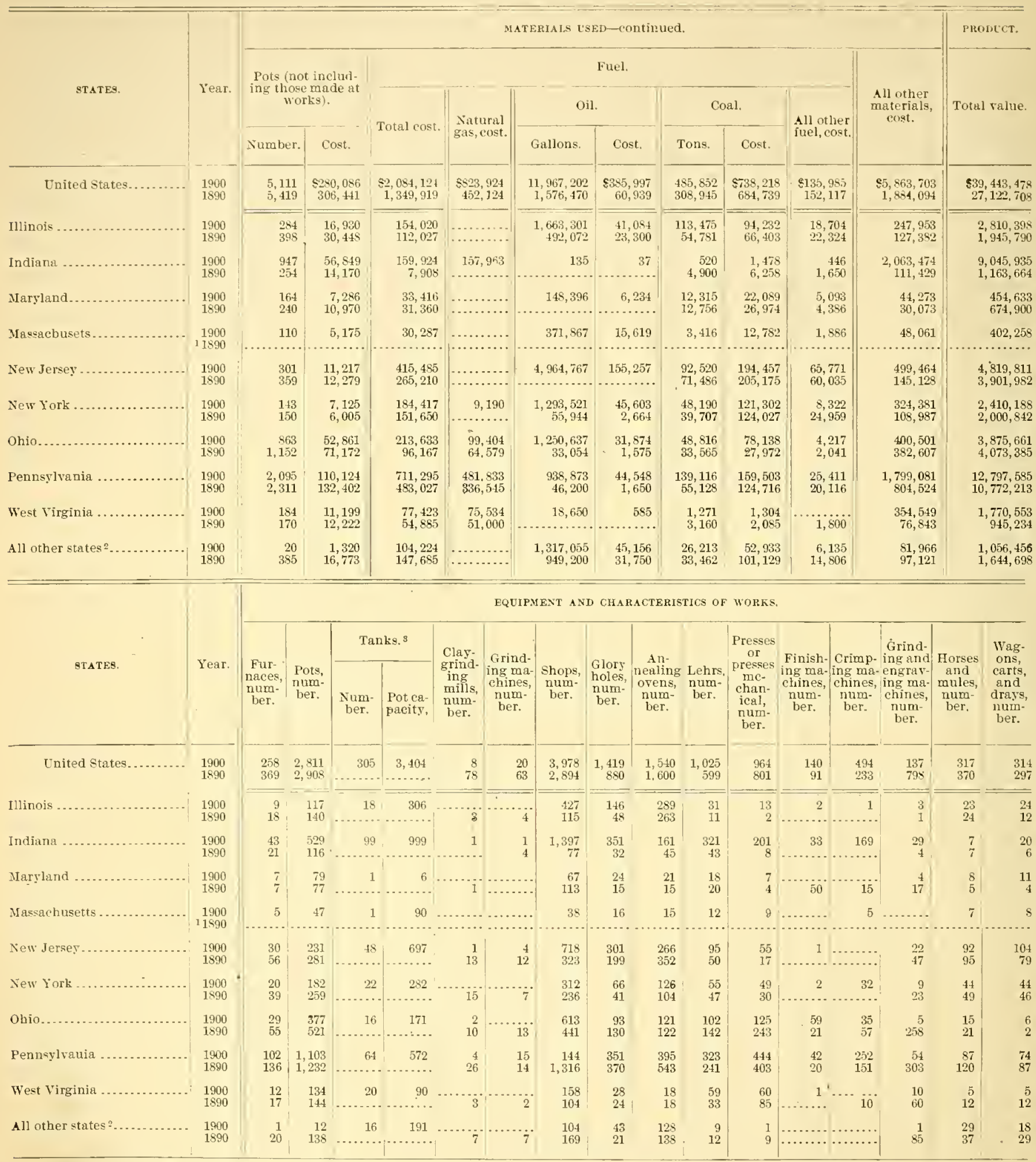

IIncluded in "all other states."

2Includes establishments distributed as follows: 1900-California, I: Colorado, 1; Georgia, I; Michigan, 1: Missouri, 1; Virginia, 2; Wiseonsin, 1. 1390-California, 1: Colorado, 1; Georgia, 2; Kentucky, 2; Maryland, 2; Massachusetts, 2; Missouri, 2; Wisconsin, 1. 
Table 8 shows that there were 231 establishments engaged in the manufacture of pressed and blown ware and bottles and jars during the census year, as compared with 194 in 1890 , an increase of 19.1 per cent. Of the number in operation in the census year, 84 manufactured pressed and blown flint and lime glassware. such as tableware, jellies, common tumbler's, goblets, lamps, chimners, lantern globes, shades, globes, gas and electric lighting goods. blown tumblers, stem ware, bar ware, opal ware, cut glass, ete. The remaining 147 establishments manufactured hottles and jars in erery variety of flint, green, and amber glass. As several establishments had products in both of the abore classes and a fair division of their business in each branch could not be made, it was necessary to consolidate the reports of the two divisions. The total value of pressed and blown ware and bottles and jars in 1900 was 45.4 per cent in excess of that reported in 1890, the totals being $\$ 39,443,478$ and $\$ 27,122,70$, respectirely. Of the total value of pressed and blown ware and bottles and jars in $1900,55.9$ per cent was the ralue of bottles and jar's and 44.1 per cent that of pressed and blown ware, as shown in Table 14 . Of the total value of all glass manufactured during the census yean, the value of bottles and jars was 38.3 per cent and that of pressed and blown ware, 30.2 per cent.

Pennsylvania lanks first with 32.4 per cent of the total value of products in the manufacture of pressed and blorrn ware and bottles and jars in 1900 . It was first also in 1890, with 39.7 per cent of the total value of products. Indiana, owing to its natural gas, ranked second in 1900 , with 22.9 per cent, and sixth in 1890 , with 4.3 per cent of the value of products. New Jersey was third in both 1900 and 1890, with 12.2 and 14.4 per cent of the value of products, respectively. Ohio was in fourth place in 1900 , with 9.8 per cent of the ralue of products, but in 1890 was second, by reason of its gas fields, with 15 per cent of the total ralue of products. Illinois in 1900 retained the rank held in 1890. fifth place, while New York dropped from fourth place in 1890 to sixth place in 1900 , on account of the western movement of the factories during the last decade. Reference to Table 14 shows that Pennsylvania leads in the production of pressed and blown ware, reporting 49.5 per cent of the total value of products, while Ohio and Indiana, the next two in rank, report 16 per cent and 15.8 per cent, respectively. West Virginia and New York report 8.1 per cent and 6.9 per cent, respectively. Indiana was the leading state in 1900 in the manufacture of bottles and jars, showing 29.2 per cent of the total value of products; New Jersey, 20.5 per cent; Pennsylvania, 19.2 per cent; Illinois, 12.4 per cent: New York, 5.5 per cent; and Ohio, 4.9 per cent.

The number of establishments reported in 1900 as engraged in the manufacture of pressed and blown lime and flint glassware and bottles and jars was $6 \check{0} .1$ per cent of the total number of glass-manufacturing estab- lishments of all kinds. In 1890 they were fif per went of the total number. The amount of capital invested in this branch of the industry in 1900 showed an increase of 53.9 per cent over 1890 . The average number of wage-carners employed in 1990 was 24.3 per cent greater than in 1890 , while the total amount of wages paid showed an increase of 31.5 per cent orer 1890. There was an increase of 24.3 per cent in the average number of men employed and 27.5 per cent iu their wages; the number of women increased 93 per cent and their wages 168 per cent. The increase in the number of women employed was due largely to the development of the manufacture of decorated ware during the last decade, giving employment to many young women. The average number of boys (practically all children in glass factories are boys) increased only 5.6 per cent and their wages 39.9 per cent. The small increase in the number of boys between 1890 and 1900 was duc largely to the strict enforcement of the truant school laws in the principal glass-manufacturing states, which cansed a great searcity of boys, particularly in the bottle factories, and also largely accounted for the increase of 39.9 per cent in wages. The difficulty of obtaining boys is confined to establishments making pressed and blown ware and bottles and jars, practically none being employed in building-glass factories. Their chief duty is to carry the ware from the blower or presser to the annealing department and to attend to the molds, important items in the operation of the factory, so that their absence causes a general curtailment of production.

One result of this state of affair's was a general effort to invent means for dispensing with boy labor. One apparently practicable plan to this end is the use of a portable sheet-iron box or oren, capable of being kept at a satisfactory temperature, into which the ware is placed as it comes from the mold. When the "iron boy" is filled, two laborers carry it to the annealing department and unload the ware into the annealing ovens or lehrs. In this way, it is claimed, sereral laborers can handle the production of the factory with as much speed and at less cost than when bors are employed. As a result of a recent scarcity, the plan of employing young women or girls was agitated, but this aroused such a stom of indignant protest from all workers that it was never put into operation.

The total cost of materials used in 1900 in pressed and blown ware and bottle and jar manufacture was 60.3 per cent greater than in 1890 . The total cost of fuel reported in 1900 is 54.4 per cent in excess of the total reported in 1890 , the reported value of natural gas used being 82.2 per cent greater; however; a number of establishments owning their source of supply in 1890 and 1900 made practically no report of cost for gas fuel, but charged the expense against cost of maintenance. A remarkable increase in the use of oil as a fucl is shown, the number of gallons used being 659.1 
per cent greater in 19011 than in 1890 . while the cost increased 533.4 per cont. "The averige cost per gallon in 1900 was 8.2 cents, as compared with 3.9 cents in 1.:10. Nincty-four and threctenths per cent of the quantity of fuel oil reported as nsed in glass manufacture in 1:roo was used by the factories which manufactured pressed and blown ware and bottles and jars. 1 large number of small tanks operated with fuel oil, and a lane quantity was used in the glory holes. the number of which in the cntire industry in 1900 was 61.3 per cent in excess of the number reported in 15.90. There was an increase of 57.3 per cent in the quantity of coal used and an increase of only 7.8 per cent in the cost. The arerage cost per ton in 1900 was $\$ 1.52$. as compared with $\$ 2.2$ per ton in 1890 . The increased use of the tank furnace. with coal-gas producer's using a cheap yrade of slack coal. was the cause in a large measure of this decided decline in the arerage cost per ton.

The total number of furnaces in this branch of glass manufacture in 1900 shows an increase of 52.6 per cent orer the number leported in 1890. and the total pot capacity increased 113.7 per cent: of this capacity, 54.8 per cent is contained in continuous and day or intermittent tank furnaces, which were of insignificant number prior to 1890 . The use of the continuous tank in this branch of the industry is confined almost entirely to the bottle and jar trade, only 10 being reported in the pressed and blown ware establishments. Bottles of all kinds are being made from the continuous tank, and the bulk of the fruit jar and beer bottle production is made in this manner. Within the last few years flint glass for bottles and jars of such a fail quality has been made in the tank furnace that, taken in conncetion with the cheaper cost of production and the increased output, flint glass made in tanks for bottleware is rapidly superseding the pot-made flint glass. The adoption of the tank for manufacturing flint-glass bottles has been so general that at the close of the census rear the flintglass bottle blowers, numbering orer 2.000, who since 18 is had been joined in a trades union with workmen in 13 other blanches of the Hint-glass trade, were preparing to leave that association and join with the green bottle blowers' union. This step was finally taken one rear later by a large number.

A small decrease in the total number of annealing orens in use in pressed and blow $\mathbf{n}$ ware and bottle and jar manufacture was reported in $1900^{\circ}$ as compared with 1890. and at the same time the number of annealing lehrs increased 71.1 per cent, showing that the annealing oven is being displaced br the faster and more economical lehr. The principle of the oren method of amnealing is the gradual reduction of the heat. while the lehr method is based on the priuciple of gradually withdrawing the glass from the heat. The new method lends itself more readily to scientific exactness in securing ressults and. being continuous in operation. makes it possible to handle the increased output of the furtory in much less time and at smaller cost.

The manuficture of bottles and jars is the oldest branch of the glass industry in this country, the first glass factory, at Jamestown, Va., in 1ros. prohably operating cxclusively on bottles. It has always formed a prominent part of the industry and in the last clecude. has made greater prowess than any other branch of glass manufacture. The tank furnace. machinery, and improved factory equipments and facilities have resulted in a large increase in the ralue of products.

Specialization is the prevailing characteristic. A few years agro it was customary for each establishment to manufacture a large variety of ware, and the workman as a rule was accustomed to make a little of ererything; but it is now the tendency to restrict the output of the factory to a particular article, and the workman is an expert in one branch of his trade, the general workman having given way to the specialist capable of maintaining the highest speed. This specializing tendency is particularly nurked in the manufacture of fruit jars and beer bottles. For years bottles rere made in connection with window glass from the same furnace. A surviral of this is present in the trade to-dar with 5 establishments, manufacturing both window glass and bottles; separate furnaces are used, however.

In no branch of the glass industry has the use of machinery made so great a change as in bottle and jar manufacture during the Jast decade, and especially the last four years. This applies particularly to the manufacture of fruit jars and wide-mouth ware, such as raseline jars. jam jars, etc. Prior to 1590 the manufacture of machine-made wide-mouth bottles or jars was largely experimental, and practically no fruit jars had bcen made by machinery. Since that date the enormous production of small wide-mouth articles, such as vaseline jars, of which one establishment in New York uses 10.000 .000 rearly, has been made almost entirely by machines. while fully 90 per cent of the fruit jars are machine-made. and it is only a question of a rery short time until the fruit jar will be made exclusively in this mamner. The results so far attained indicate that in a few rears the bulk of the entive wide-mouth bottle production will be made by machinery.

Prior to the use of machiner, , the method of manufacture of wide-mouth warc was to gather the glass from the furnace on a blowpipe, forming it to a suitable preliminary shape in a block or on a marrer, and then inserting the glass in a mold and blowing to the desired form. After separating the glass from the blowpipe, a ragged edge of superfluous glass remained attached to the neck of the articlc. which had to be chipped and ground off to make the product salable. The manufacture of the Mason fruit jar, which since it was patented. in 1858. has constituted 90 per cent of the fruit jar ploduction, has been most completely revolutionized by machinery. Prior to 1896 the glass was gath- 
ered trom the furnace upon a blowpipc, was then blocked or rolled iu a hollow bloek to get a preliminary shape, then swung by the blower and blown up, rolled on a flat slab or marver, and again blown until it was just large enough to admit of being inserted in the blow mold. The mass of glass was then put into the mold and blown up, so as to completcly fill the mold and form a collar ot surplus glass extending abore the top of the jar about an inch and a quarter. Above this collar was the remainder of a thin bubble into which the blower had formed the glass outside the mold so as to separate it from the blowpipe. This collar and bubble constituted the "blow-over," which had to be removed before the jar was markctable. After being annealed the jar was taken by a workman who, with a file. chipped off most of the "blow-orer" and then filed it down as smooth as possible, leaving about one-sixteenth of an inch of the collar remaining, which was finally removed from the jar by the grinding machine. Then the jar had to receire a thorough washing by hand to remore all particles of broken glass and sand resulting from the chipping and grinding. After being caretully dried, the jar was at last ready to pack. The speed with which it was necessury to perform the operations of chipping. grinding. Washing. and drying made the risk of breakage great, being estimated at the rate of from 8 to 20 per cent.

Br the use of machinery the costly " blow-over" is aroided by first pressing the neck of the jar to finished form and then forming the body of the jar by blowing; so that when the jar leares the biow mold to be annealed it is, so far as form is concerned, a marketable article. The process patented July 11. 1882, by Philjp Arbogast, of Pittsburg. Pa.. has been the basis for all machinery used in the manufacture of jars and wide-mouth bottles. He employed two separate molds, a press mold and a blow mold. Sufficient glass to make the desired article was taken from the furnace on a solid rod or punty and dropped into the press mold, the required quantity being separated from the mass on the punty by shears in the hands of a workman. A lever operated by the workman then brought down a plunger into the mold, pressing the mouth or neck of the article to finished form and pressing a wind cavity in the dependent mass of glass to aid in the blowing operation. The plunger being withdrawn, the mold was opened, and the ring inclosing the pressed neck with the dependent wass of glass was carried to the blow mold and inserted, after which the body of the artiele was blown up to the desired form. From 1884 to 1893 this process was followed in a small way on large candy and druggists' jars, wide-mouth bottles, raseline and jam jars. milk jars, and tableware, such as bowls, pitehers, sugars, and creams, but the principal produets were large drug and candy jars, which, after having the necks pressed to the finished form, were taken 'out of the press mold and greatly inereased in size by manipulation of the blower before being placed in the blow mold. In $1 x y$ the process began to be more extensively uscd on vaseline jars.

The idea of dispensing with the manual operation of transferring the glass from one mold to another was patented in England in 1886, both molds being combined into one by the usc of sliding parts. About the same time the idea of placing a series of molds on a revolving table was also patented in that country, and patcnts were granted in the United States in 185.4 on both derices, but they were nerel put into practical use. In 1896 an American combined the consolidated mold and rotary table. On a rotating table is placed a series of fire scparate, duplicate. double molds, each mold containing an outer blow section haring a ring integral with it in which the nerk of the article is pressed, and a telescopic press section rising within the blow section and receiving the glass, forming. with the neck of the blow section, a press mold. The glass is dropped into the combined mold when in this press mold position, and the table rotated, bringing the mold under the plunger. which enters it and presses the neck, and wind carity into the dependent mass of glass. The plunger is withdiawn. and another rotation of the table brings the mold under the blow stem, the telescopic press section of the combined mold haring dropped in the meantimc, exposing the glass blank within the blow section. The bottom plate is inserted and the air admitted to expand the glass blank to the form of the blow mold. The next rotation of the table brings the mold to where it is opened by a boy, and the finished article is taken out and remored to the annealing oren.

All of the above operations are performed simultancously, a finished article being produced at each rotation of the table. On such a machine the first conmcrcially successful machine-made Mason fruit jar was manufactured in July, 1896, at the plant of the Atlas Glass Company at Wrashington, Pa. The numerons jar and wide-mouth bottle machines now in use have either separate blow and prcss molds arranged near together on a revolving table so that the shifting of the glass from one to the other is almost instantaneous, or hare the molds combined in one. In all, the basic principle is the pressing of the finished neck and the subsequent blowing of the body. Compressed air for blowing and electricity for motive power have added much to the specd of the operation. The machine has a much greater productive capacity than is possible br the old hand method of blowing, and has reduced the cost of manufacture more than a third. Loss br breakage has been reduced to aminimum, while the finish of the ware is far supcrior to that of the liandmade article.

So far, the manufacture of narrow neck bottle ware by machinery is not berond the experimental stage in this country, although commercial success is claimed in Germany and Russia. The claim is made by the best authorities that the manufacture of narrow neck bot- 
tles by mathinery will soon be perfected and become as goneral as the mechanical production of wide-mouth ware. The method employed at present in making narrow neck bottles is to yather a suirable amount of glas: from the furnace on the blowpipe. to roll it on a marrer or turn in a block. to swing and blow and again roll on the marrer to give it the proper form for insertion in the mold, where it is blown. forming the body and neck of the bottle. The article is then taken from the mold and carried to the glory hole. where the top of the neck is reheated and the ring or lip of the bottle neck is formed by the workman with a finishing tool, after which the bottle is ready for anncaling. The greatest adrance made so far in the mechanical prodnction of narrow neck ware has bcen in the finishing process, although the finishing machine. as ret, is used to but a limited extent.

The number of frnit jars reported in 1900 was 789.298 gross of different sizes-pints, quarts, and half gallonsvalued at $\$ 2,935.036$. It is estimated that abont 90 per cent of these were the Mason patent jar, which has a screw threaded neck for a metallic cap which presses down a rubber band on the shoulder of the jar, making a perfect seal. The other jars manufactmed were more expensire kinds with special sealing derices, of which that with an all-glass top was the farorite. There were $3 \pm$ establishments engaged in the mannfacture of fruit jars during the census year, 6 of which made that class of ware exclusirely. The largest frnit jar plant in the world, with a daily capacity of $2+0.000$ jars, all machine-made, is in Indiana. Comparison with the statistics of the last two censuses shows a great derelopment in this branch of the industry, cansed principally by the introduction of the continuons tank in the last decade and the adoption of machinery within the last four years. In $1890,268.978$ gross of fruit jars were reported, valued at $\$ 1,390.430$. There was an increase of $193 . \pm$ per cent in the number manufactured in 1900 orer 1890. The arerage value per gross in 1900 was $\$ 3.72$ as compared with $\$ 5.17$ in 1890 , a decrease of 28 per cent in the value per gross.

The statistics of fruit jars manufactured at the census of 1880 are incomplete. ret the total of $1+8,271 \mathrm{gross}$ reported for Pennsylrania. New York, and New Jersey probably comprised rery ncarly the prodnction of the entire conntry. The increase in the cquantity manufactured in 1900 orer 1880 was 432.3 per cent. No fruit jars were reported in Indiana in 1S80; bnt this state headed the list in 1890 with $83.270 \mathrm{gross}$, valued at $\$+40,657$. $01^{\circ} 31$ per cent of the total production, and also in 1900 with 559,549 gross. ralued at $\$ 2.106 .250$. or 70.9 per cent of the total prodnction. Pennsylrania, which was first in 1880 in the mannfacture of fiuit jars. 67,770 gross haring been reported. was third in 1890. with a prodnct of $47.250 \mathrm{gross}$, ralned at $\$ 233.125$, and second in 1900 , with 115.000 gross, ralued at $\$+36,104$. Ohio was second in the mannfacture of fruit jars in 1890 by reason of the discovery of natural gas. fin. 726 gross, ralncd at $\$ 296$. 065 . haring been reported. while in 19100 the number had dwindled to 2.000 gross of a spceial kind, valued at $\$ 8.000$. In 1880 there were 51.749 gross reportcd as manufactured in New .Jcrscy: in 18:10, 33.406 gross, valued at 8181.410 ; and in 1400 this state reached third place. with 61.871 gross. valucd at \$192.467. In New York there were 28.752 gross manufactnred in 1880: in 1890 thcre were reported 9.500 gross. ralued at 555.000 : and 31,235 gross. valued at $\$ 128.965$. in 1600, an increase in the number manufactured of 228.8 per cent orer 1590. The statistics for Illinois show a large decrease in fruit jars manufactured since 1890, the number reported in 1900 being 1,500 gross, valued at $\$ 9,000$, compared with 20,750 gross in 1890 , ralned at $\$ 103,798$. In West Virginia, from which no fruit jars were reported in either $1880 \mathrm{or} 1890$, there were manufactured 14,643 gross. valued at $\$ 3,750$, in 1900.

At the close of the census rear large quantities of fruit jars, ronghly estimated at $3 \pm 0.000$ gross, wcre being held in stock and were controllcd by a selling agency formed among the principal manufixtnrers. A large portion of this stock was neld by one firm. which had thousands of jars stacked in an open field. This stoek had accumulated for sereral years and was held in prospect of the approaching failnre of the natural gas and the consequent adrance in prices.

The manufacture of prescription bottles, rials, and drnggists' ware was carried on by $7 \mathrm{i}$ establishments in 1900, sereral of the largest factories in the country being operated almost exclnsively on this class of goods. The ralue of these prodncts in 1900 was 21.5 per cent of the total ralue of all bottles and jars manufactnred. The statistics reported in 1890 of bottles and jars manufactured are of no value for comparative purposes, as they were not complete. Howerer. the total number of bottles reported in that year. exclusire of beer bottles. was $2,170,961$ gross. The average ralue per gross of this class of ware in 1900 was $\$ 1.92$. Which was a considerable reduction from the ralne per gross in 1890 . This was due to the increased quantity of ware prodnced from the continuons tank furnace. Of the total quantity of this class of ware manufactured in the United States in 1900, 30.2 per cent was made in New Jerser. constituting 28 per cent of the total value, the arerage value per gross for the state being $\$ 1.79$. Indiana ranked second, with 25.7 per cent of the total quantity and 25.4 per cent of the total ralue of the products, the arerage value per gross for the state being $\$ 1.90$. Pennsylvania, by reason of much of the product of that state being of higher grade, closely followed Indiana in the ralue of the products, producing 25.4 per cent of the total ralue and 22.7 per cent of the total quantity, the average ralue per gross being \$2.12. In Illinois 11 per cent of the total quantity and S. 6 per cent of the total ralue was mannfactured. the arerage raluc per gross for 
thestate being $\$ 1.5 \%$. A large part of the southern trade wassupplied by that state. The manufacture of homeopathic vials was carried on by 4 glass making cstal). lishments. These vials were also made during the census year in a large number of small shops where the tubing is bought and reworked. No account of these shops is taken in this report. The American prescription bottle has no superior in form and finish, and is far in advance of the ware manufactured abroad. Export shipinents of this class of ware direct from factories in 1900 were reported to Canada, Australia, South and Central America. Cuba, Great Britain. France, Africa. East Indies, China, and Japan, of a total value of $\$ 93,094$, which represented only a portion of the actual exportation, as the most of the trade was done through exporting houses.

The manufacture of beer, soda, and mineral water hottles in 1900 was reported by 75 establishments in 15 states, the total value of which was \$5, 075,068, ol* 23.4 per cent of the total ralue of all bottles and jars manufactuled. Several establishments were employed almost exclusively in the manufacture of heer and soda bottles, the bulk of the trade being done by them. Plans were being prepared at the close of the census year for 6 new establishments to manufacture beer and soda bottles exclusively, while increases of capacity among established plants rere general, nearly all being in the line of continuous tanks. Demand for ware in the census rear was extraordinary, the lome consumption being unusually large, while large quantities of bottles filled with beer were shipped to Cuba and the far East. 'The export trade in beer and soda bottles with Mexico reached its highest derclopment during the census year, direct factory shipments aggregating 21,147 gross, valued at $\$ 66,333$, being reported for that country. The manufacture of mineral water bottles largely increased during the decade and was unusually large during the census year. By far the largest part of the production in this branch of the industry was made from the continuous tank furnace.

The general use of the tank and better facilities for the maintenance of a high rate of speed by the workmen have resulted in a great increase in the average factory output within the last ten years, yet consumption at the close of the census year was demanding still greater capacity, and prices were at a high point. In 18.40 a production of 204,948 gross of beer bottles was leported, the figures probably not being complete, but showing nearly all of the country's production in that Jear; this was exceeded in 1900 by Illinois alone, with 4 establishments reporting. As in 1890, Illinois in 1900 was first in the manufacture of beer, soda, and mineral water hottles, with 26.3 per cent of the total value and 30.1 per cent of the total quantity manufactured in the United-States. Pennsylvania ranked second in value of products, with 17.8 per cent of the total, but the quantity manufactured was only 10.9 per cent of the total quantity. Fstablishments in ()hio reported 12.6 per cent of the totul value and 16.2 per cent of the total number of gross, while the production in New York constituted 9.9 pel cent of the total quantity and 4.3 per cent of the total value: A large percentage of the total value and quantity was reported under the head of "all other states," which came chiefly from Misconsin and Missouri, each having a large establishment deroted to the exclusive manufacture of this class of ware. California, Colorado, Georgia, Michigan, and Virginia were the other states included under this head. New Jelsey, with a production slightly lesis in quantity. led Indiana in the total value of beer, soda, and mineral water hottles manufactured. Following Indiana in this class of ware were Maryland, West Virginia, and Massachusetts, in the order named.

There were 81 establishments engaged in the manufacture of flasks and liquor bottles in 1900, the total value of the product being 11.1 per cent of the total value of bottles and jar's manufactured, Indiana heading the list with 50.2 per cent of the total ralue and 61.4 per cent of the total quantity. 'There were sereral small establishments equipped with tank furnaces in this state operating exclusively on flasks with rery cheap gas fuel, and cheap unorganized labor, that created considerable demoralization in prices and in the trade of the old establishments. To counteract this, the American Folint Glass Worker's' Union, to which the or'ganized flask workers belong, at the close of the census year was erecting a tank factory in Indiana to be operated exclusively on Hasks, which were to be sold at prices to compete with these new firms, and thus to either force them out of the business or cause them to maintain prices and working conditions equal to those in force among organized manufacturers. This movenent is unique in the history of trades unions, and is based on the principle that there is greater economy and efficiencr in direct business competition than in the old method of taking men out on strike and supporting them on a relief roll. Pennsylrania was next to Indiana in the manufacture of flasks and liquor bottles. 14.5 per cent of the total quantity and 15.6 per cent of the total ralue being nanufactured in that state. Liquor bottles and flasks were also manufactured in California. Georgia. Illinois, Maryland, Massachusetts, Michigan, New Jersey, New York, Ohio, Virginia, W ${ }^{\top}$ est Virginis. and $\mathrm{W}$ isconsin.

The manufacture of milk jars or bottles is practically a development of the last decade. The demand his steadily increased, causing a corresponding increave in the furnace capacity used in the manufacture of this class of ware. The manufacture of milk jars was reported in 1900 by 31 establishments, 13 of which were located in Pennsylrania. The total ralue of milk jars of all sizes mamufactured in 1900 was $3 . \pm$ per cent of the total value of all bottles and jal's manufactured. The average value per gross for the United States wis 
84.94. The mechanical production of milk jals is commercially possible, and it is plobable that a large part of the product will be made by machinely during the present decade. The manutacture of milk jars waw onc of the most rapidly expanding branches of the glass trade at the close of the census year, the overwhelming merits of such a package for milk becoming more widely lecoginized and the demand steadily increasing. Pennsylvania led the productire list, with 55.1 per cent of the total quantity and 59.6 per cent of the total value. The percentages of the total quantity and total ralue of milk jars manufactured in the other states in 1900, are as follows: New Jersey, 13.5 per cent of the quantity and 14.7 per cent of the value: Indiana, 13.4 per cent of the quantity and 7.6 per cent of the value; Illinois, 5.1 per cent of both quantity and ralue; New York, 4.7 per cent of the quantity and 4.6 per cent of the value; Ohio, 4.1 per cent of both quantity and value; West Virginia, 3.1 per cent of the quantity and 3.2 per cent of the value.

The manufacture of bottles for patent and proprietary medicines is largely confined to the states of New Jersey, Illinois, and Indiana, although $4 \bar{r}$ establishments in 8 states were reported as engaged in the manufacture of such products. The value of bottles for' patent and propietary medicines manufactured in 1900 was 12 per ccnt of the value of bottles and jars of all kinds reported. The combined production of New Jersey, Illinois, and Indiana was 88.6 per cent of the total quantity for the United States. Bottles of this kind are made of a cheaper grade than prescription bottles and are used in steadily increasing quantities. a large quantity being exported filled. New Jersey for a long period has been first in the manufacture of this class of ware, and in 1900 there was reported from that state 46.4 per cent of the total quantity and 53.7 per cent of the total value for the United States. From Illinois was reported 23.4 per cent of the total quantity and 19 per cent of the total value; and from Indiana 18.9 per cent of the total quantity and 14.5 per cent of the total value. Bottles for patent and proprietary medicines were also manufactured in Pennsylyania. New York, Ohio, Maryland, and Georgia.

The manufacture of bottles and jars for the packing and preserving industries, exclusive of the enormous production of fruit jars, has steadily adranced during the past decade, owing to the remarkable growth of the above interests and the increasing recognition of glass as the ideal package. In this branch of the bottle and jar industry the valuc of the product in 1900 was 9.8 per cent of the total value of all bottles and jars manufactured, and 45 establishments in 10 states reported. The products covered a wide range ot glass food packages, the average valuc being $\$ 2.70$ per gross. The manufacture of machine-made ware in this line is increasing, although constituting as yet a rery small proportion of the total. The 3 leading states in the manufacture of bottles and jars tor packers and preservers were Nen .Jersey. Indiana, and Pennsylyanla. In New Jersey. 35.6 per cent of the quantity and 24.3 per cent of the value of these products was manutactured; in lndiana. 31.6 per cont of the quantity and $32 . \pm$ per cent of the value: and in Pennsylvania, $14.5 \mathrm{per}$ cent of the quantity and 19.8 per cent of the value. Illinois tollowed, with $10.3 \mathrm{pel}^{\circ}$ cent of the yuantity and 9.2 per cent of the value. This class of ware was also manutactured in Ohio. New York. California. West Virginia, Maryland, and Georgia; these states reporting in the order given as to quantity and value of product.

The number of demijohns and carboys manufactured in 1900 was $\$ 3,243$ dozens, valued at $\$ 206,061$. The average value per dozen for the several states varied with the proportion of the state's output of the more expensive carboy or the cheaper demijohn, the average value of the carboy being about twice that of the demijohn. New Jersey was first in the value of demijohns and carboys manufactured in 1900 , with 42 per cent of the total value, followed by Illinois with 23.5 per cent of the total value, Pennsylvania with 17.9 per cent, and New York with 9.2 per cent. Under the head of "all other" products," bottles and jar's which were not specified, valued at $\$ 940,277$, were reported. A large variety of ware was embraced under this head: During the census year the manufacture of large glass jars and retorts for laboratory use and for water coolers was successully accomplished in this country. the process having been blought from Flance.

There was no such close organization of manufacturing interests in the bottle and jar industry during the census yeal as in the plate glass, window glass, and tableware industries. Eastern and western manufacturers of bottles have relied upon a common understanding to regulate prices, with varying success. particularly in some lines such as flasks and prescription bottles. The manutacture of beer bottles was controlled by a few firms, and very satisfactors results in keeping prices uniform were the rule. The prices of fruit jars were regulated by a selling agency agreement among controlling manufacturing interests. The workmen in both the green and fint bottle and jar trades were well organized and their rules as to duration of factory operation and a uniform scale of wages, which affected a large majority of the factories in all branches of glass manufacture, were the strongest factor's in maintaining uniformity of prices. 'The green bottle blowers' organization, the Glass Bottle Blower's' Association, organized about 1877, is one of the best managed and most progressive trades unions in the United States, and had a membership of about 4.000 and about $\$ 100,000$ in cash in the treasury at the close of the census year. The organization of flint or prescription bottle blowers numbered about 1,500, and formed a branch of the American Flint Glass Workers' Union, one of the largest trades unions in the country. The scale of 
wages and the duration of the summer stop of the factories are tixed each year at a meeting of a joint committee representing organized workers and manufacturers. The only company stores in the glass trade in 1980 were in the bottle and jar branch of the industry. There were 10 of these stores, but in only two instances were the glass workers compelled to trade with them, as had been customary a short time before, the blowers union haring conducted a successful strike chietly against the company store srstem. In 1890,20 company stores were reported, 11 in connection with factories making bottles and jars and glassware, 8 in window glass works. and $1 \mathrm{in}$ the plate glass branch. In 1880 there were 27 reported, as follows: 13 in connection with factories making bottles and jars and glassware. 12 in window glass works, and 2 in the plate glass branch.

Table 9 is a statement. by states, of the number of bottles manufactured. classified by capacity.

TABLE 9.-NUMBER OF BOTTLES MANUFACTURED, CLASSIFIED BI CAPACITY, BY STATES: 1900.

\begin{tabular}{|c|c|c|c|}
\hline \multirow[b]{2}{*}{ STATES. } & \multicolumn{3}{|c|}{ BOTTLES. } \\
\hline & $\begin{array}{c}\text { A-ounce } \\
\text { and under. } \\
\text { number of } \\
\text { gross. }\end{array}$ & $\begin{array}{l}4 \text { to } 16- \\
\text { ounce. in- } \\
\text { clusive, } \\
\text { number of } \\
\text { gross. }\end{array}$ & $\begin{array}{c}\text { Over } \\
\text { 16-ounce, } \\
\text { number of } \\
\text { gross. }\end{array}$ \\
\hline trnited States.... & $2,462,694$ & $3,055,204$ & $1,228,719$ \\
\hline California.. & 4. 600 & $22,+86$ & 25,187 \\
\hline Georgia.. & 13,000 & 17,000 & 7,350 \\
\hline 1llincis. & 428,077 & 430,636 & 239,285 \\
\hline lndiana... & 562,345 & 872,318 & 199,947 \\
\hline Maryland ...... & 113,898 & 48,960 & 8,969 \\
\hline Mas achusetts . & & 4. 865 & 1,561 \\
\hline Michigan ....... & 3,876 & 10,425 & 1,670 \\
\hline Jew Jersey ........... & 764,385 & $\begin{array}{r}46,667 \\
614,385\end{array}$ & $\begin{array}{r}23,333 \\
130,046\end{array}$ \\
\hline New York.......... & 57,321 & 196,790 & 254,074 \\
\hline Ohio ..................... & 74,015 & 195,054 & 94,338 \\
\hline Penasylvania ... & 405.528 & 496,670 & 199,310 \\
\hline Virginia .... & 34,000 & 22.000 & 9.000 \\
\hline West Tirginia... & 1,649 & 34,948 & 6,649 \\
\hline Wisennsin & & 42,000 & 28,000 \\
\hline
\end{tabular}

It is possible that the statistics presented in the abore table are not strictly accurate, as several establishments were unable to furnish nore than an estimate of the number of bottles of each size manufactured. The total number of the three classes of bottles exceeds the total number reported in Tables 12 and 14 as "prescriptions, rials, and druggists" ware," "beers, sodas, and minerals." "liquors and flasks," and "patent and proprietary." This is probably accounted for by the fact that a large number of bottles included in the statement were not reported under either of the foregoing classifications, but were reported on the schedule under "all other products."

Pressed and Blown Glassware.-Pressed and blown lead and lime glassware manufactured in the Lnited States is characterized by purity of color, excellence of design and finish, and cheapness of cost. The United States has been preeminent in the manufacture of pressed glassware ever since the invention of the process, which occurred ahout 1827 at a little plant in Sandwich. Mass. as the result of a suggestion of a carpenter who knew nothing of glass manufacture. His idea that molten glass could be pressed into any desired shape was at first regarded as absurd by cxperienced glans manufacturers. Prior to this all glasware was blown, either offhand or in a mold, which required much greater skill and more time than the pressing operation.

About 37 ycar's after the first glass press was constructer another important discovery was made, which so improved the composition of the batch for lime glass that, in purity and brilliancy, lime glassware was made to rival the more expensive lead glassware. Lime glass had been used in Europe and England for centuries in the manufacture of window glass, bottles and jars, and common tableware, and from an early period it had been used in the United States in the manufacture of tablewarc. But it was so inferior in purity and luster that it could not compete with lead glass, and was restricted to the cheapest and lowest gracle of ware.

In 1864, according to the authority noted abore. William Leighton sl., a glass manufacturer of Theeling, W. Va., by the substitution of bicarbonate of soda for soda ash, and a better proportion of the materials in the batch, manufactured a lime glass that equaled in beauty the finest lead glass. This placed lime glass on a basis of competition with lead glass at less than onehalf the cost. The almost immediate effect was a complete revolution in the manufacture, the production of lime glass rapidly increasing, while that of lead glass for tableware was soon reduced to a comparatively small quantity. The lime glass was not only cheaper. but had to be worked quicker than the lead glass. resulting, in connection with the use of the press. in a largely increased output.

The quantity of pressed ware manufactured has been greatly increased in the last decade br the remoral of the arbitrary limit placed on the number of pieces to be made in a "turn" by the worker, and by the improrement of the old-style press by adding a rotating table carrying a series of molds, and operated by steam, compressed air, or electricity. The effectiveness of these improrements has been further increased br elaborating on the old wind system for cooling molds and workers. This increase in the speed of the old press without changing its basic form. and in that of the fire polishing and finishing operation, have been the notable changes during the last twenty years.

The eflort to increase rapidity of production, especially in the last decade, was the principal characteristic of the pressed-ware trade. So well has this succeeded by the use of the improred press and continuous tank. that it has resulted in a large increase in the quantity manufactured, of common tumblers and jelly glasses. cheap, unfinished tableware, conmon lamps, etc.. and a

${ }^{1}$ Tenth Census of the United States, "Report on Glass Mamnfacture," by Joseph D. Wreeks, sperial agent. page $5 s$. 
large reduction in cost, although the best grade of pressed ware is still made on the old hand press. For years American pressed tableware has been unrivaled in brilliancy and in its close imitation of the real cut yliss, the fire-polish finish being the greatest factor in this success. In beanty and valiety of design, pressed tableware has equaled if not surpassed the real cut ware, new designs being produced each rear in great profusion and at large cost.

During the last decade great nechanical progress has been made in the blown glass branch of the industry. but not to such an extent as in the production of fruit jars. Since 1897 a large number of thin blown tumblers have been made by machinery, and the same machine has been successfully applied to the manufacture of lamp chimneys, although trade conditions have restricted its advantages and prevented its operation in the manufacture of the latter to the extent reached on tumblers. In the manutacture of both tumblers and lamp chimneys, the machine greatly increases the output and lessens the expense of skilled labor. The machine has a circular table revolving around a central column or standard, the table carrying a series of duplicate molds, usually six. After the ball of glass has been gathered from the furnace on the blowpipe to the size required for the desired article, it is placed in the mold, which is closed, and the blowpipe held in place perpendicularly over the mold by a clamping derice at the top of the machine, which engages with the upper end of the blowpipe. Orer the mouthpiece of the pipe is placed a rubber hose which leads to a supply of air, furnished either by a compressing pump. or, if light pressure is required, as with some tumblers, by a tan system. The mechanical rotation of the table admits the air into the pipe. which is kept revolving, and blows up the glass in the mold until it is ready to be turned out for the finishing process. Ingenious mechanism regulates the air pressure. The entire operation is performed with great rapidity and it is claimed that the output of the machinc is limited only by the ability of the workmen to supply the glass. The mechanical finishing of ware is now engaging the special attention of manufacturers. and a completel mechanical process, requiring small labor cost to perform the entire operation of finishing the ware after its removal from the blompipe or mold, is the object sought. Manufacturers generally are of the opinion that more real progress will result from improvements in the finishing process than from further improvements in the mechanical process of making the ware. While the high-speed machine is a success on ordinary ware. both pressed and blown, the manutactme of high-grade ware secms to require the sympathetic touch of the skilled workman.

The manufacture of pressed and blown ware in 1900 was done almost entirely in Pennsylvania, Ohio, Indiana, West Yirginia, and New York, only 3.7 per cent of the total value of such products being reported in
Massachusetts, Illinois, Maryland, New Jerscr. and Colorado. Specialization in manutacture was carried far in many lines, particularly in the manufacture of chimneys. tumblers, and lamps. Competition in nearly all lines was very active. particularly during the latter part of the decade, ercating a strong tendency toward concentration of capacity along special lines, so as to manufacture at the lowest possible cost. The more rapid and safer bandling of the ware, cconomy of rorking space in the factory, and facilities and conveniences for adding to the efficiency of the working force were consiclerations that received the greatest attention. Competition was so intense at the opening of the census year that all previous agreements between manufacturers as to prices were useless, and consequently prices of pressed and blown ware were unusually low. This was the principal cause of the formation of two close consolidations and additional general associations for the regulation of prices. The result was a decided improrement in prices during the latter half of the year. In July, 1899, a consolidation was effected of $T$ establishments which manufactured lamp chimneys exclusively, and on November 1, 1899, 19 large pressed and blown ware establishments, equipped with about onehalf of the available capacity of the United States, making a general line of tableware, tumblers, and novclties, came under the control of one central company. In 1891 a similar consolidation of 13 tableware establishments, principally in the immediate neighborhood of Pittsburg, Pa.. was formed, and the number of plants was increased later. During the census year this company operated only 6 factories, 3 of which were in Pittsburg.

In the early part of the census year nearly all the manufacturers of pressed and blown ware agreed in forming an association to effectively maintain prices, and so successful was this association that on many articles unusually low prices. caused by sharp competition, were succeeded by quite profitable prices, which were well maintained. The association in attaining this end enlisted the aid of the jobbers by the establishment of a liberal rebate system. similar in some respects to the plan adopted by the consolidation of window glass manufacturers in the samc year, although the latter went to the extent of forming the jobbers into an incorporated body pledged to cooperate with the manufacturing interests. The sereral consolidated companies engaged in the manufacture of glass established their headquarter's in Pittsburg, which city, although it had lost nearly all the glass factories that had made it famons as the center of American glass manufacture, controlled more completely than erer, at the close of the census year. the manufacture of glass in the United States. Pittsburg was also the headquarters of all the glassworkers' associations, except that of the green bottle blowers, which was at Philadelphia. A large majority of the skilled workmen in the pressed and blown ware 
industry were memhers of the American Flint Glass Workers' Union. which was organized in 1878, and embraced the workmen in 14 different branches of the trade. The membership was about 7,000 and the treasury contained about $\$ 100,000$. By means of this orgauization the manufacture ras carricd on under a practically uniform wage seale and with concerted action as to tactory operation.

The manufacture of tableware, which consists of pressed and blown articles in sets ranging from two or three pieces to over a thundred, of very great variety of form and size. was confined to the 4 states of Pcnnsylrania. Ohio. Indiana, and West Virginia, in the order named. Twenty-seren establishments reported products ralued at $82.617,784$, or 15.3 per cent of the total value of all ware made in the pressed and blown division of the industry, and numbering 65,514.100 separate pieces. There was a very great variety in the value of the different kinds of ware, but the average raluc per 100 pieces for the United States was $\$ 1$.

In Pennsylvania 5ั5. 6 per cent of the total quantity, and 60.6 per cent of the total value, was manufactured, and the arerage ralue per 100 pieces in that state was $\$ 1.35$. A large proportion of the product for the state was manufactured in the Pittsburg district. In Ohio 23 per cent of the total quantity, and 25.5 per cent of the total value, was reported, and the average value was $\$ 4.43$ per 100 pieces. The great bulk of the product was manufactured in the ralley of the Ohio River, $\mathrm{By}$ the substitution of glass of a cheap quality made in tanks for glass made in pots, and worked with the press at higher speed than customar' $y$, and by dispensing with the fire-polishing operation, a class of cheap unfinished tableware and other glassware was manufactured in Indiana during the closing rears of the last decade. This largely accounts for the fact that only 11.1 per cent of the total value of tableware manufactured in the United States, compared with 19.3 per cent of the quantity, was made in that state. The arerage value per 100 pieccs was \$2.31. The manufacture of tableware in IV est Virginia was conducted entirely along the banks of the Ohio River, and 2 per cent of the total quantity, and 2.8 per cent of the total value, was manufactured there, at an average value of 85.48 per 100 pieces. A considerable proportion of the product was blown ware.

Considerable rivalry exists among the manufacturers of pressed tableware in the production of attractive designs and decorations. Most of the ware is in imitation of cut ware, and so highly has the art been dereloped that a careful examination is frequently required to detect the difference. It is the custom with a majority of the estabiishments to offer new designs at the opening of each year, a large amount of money being expended to secure these designs and to prepare the required molds. The profitable life of a design, unless it is unusually popular, is limited to one season, its place being taken by some new idea expected to bet- ter catch the popular fancy. A popular design will. in one season, prove extrenely profitable. while the losse: on unpopular designs are so great as to make the expre:sion of the public's favor an exceedingly interesting matter to the manufacturer's. Popular faror has changed in the last decade from imitation cut ware to plain ware, and from that to highly decorated ware. but the imitation cut ware has been in most constant demand, although within the last few years colored ware and plain crystal with gold decorations have been strongly favored. Within the last half of the decade the manufacture of colored ware, to compete with the influx of imported Bohemian ware, has béen assuming shape, and it seems probable that this profitable field will not much longer be left wholly undisputed to the foreign manufacturer.

Tableware has long formed a large proportion of the exports of glass from the United States, by reason of its superiority of color and design. The export branch of the business received special attention in 1900, trareling represcntatives haring been sent through South America, Australia, and the United Kingdom. and a number of pcrmanent agencies were established br the larger interests. For a long period large quantities of American tableware have been used in Canada, and a field of large proportions is being opened in Australia, one glass manufacturing establishment during the census year, having made a single direct shipment to that country of 10 cars, or about $1,500,000$ pieces, a small part of which was common lamps. Thirteen establishmonts reported exports direct from factory of a total value exceeding $\$ 100,000$, to Canada, Australia, Mexico, South America, Cuba, Hawaii, England. and Germany. This represented only a small part of the total exports of tableware during the census year, as the bulk of the trade was done through exporting houses. A growing tendency has been noted on the part of the manufacturer's to export direct from the factories, and foreign needs are being closely studied with a riew to the increase of the export trade in the future.

Jelly glasses and pressed tumblers and goblets. $102,528,600$ pieces in number, ralued at $\$ 2,007,386$. were manufactured by 28 establishments in 5 states in 1900. The value of such ware was 11.8 per cent of the total value of all pressed and blown ware manufactured in the United States. The average value was 23 cents per dozen.

In Pennsylvania 36.4 per cent of the total quantity and 39.5 per cent of the total value was manufactured, and the arerage value for the state was 25.5 cents per dozen. The proportion manufactured in Indiana was 31.4 per cent of the total value and 35.7 per cent of the total quantity, at an average value of 21 cents per dozen. From Ohio was reported 9.6 per cent of the total ralue and 19.7 per cent of the total quantity, at an arerage value of 23 cents per dozen. The remaining 9.5 per cent of total value and 8.2 per cent of total quantity 
was manufactured about equally in Maryland and West Virginia, at an arerage value of 27 cents per dozen. At the close of the eensus year two large establishments. intended solely for the manufacture of jelly glasses and tumblers. were being built in West Virginia, and a large establishment was being erected in Ohio for the manufacture of the same class of ware by machinery and methods that were expeeted to still further reduce the cost and inerease the possible output.

At the censuses of 1880 and 1890 incomplete returns were made of the manufacture of tumblers and goblets. In 1880, 46.415 dozen "tumblers" were reported from Massaehusetts, 409.713 dozen from Ohio, and 2.500 .000 dozen from Pennsylvania. In 1890. 5.438,700 dozen "tumblers and goblets." valued at \$555,273. were reported as manufactured in Ohio; and $2, \pm 81,600$ dozen, ralued at $\$ 780.059$, in Pennsylvania. The use of jelly glasses and tumblers in the packing trade is steadily inereasing and there has been a steady growth in the exports.

Lamps manufaetured in 1900 numbered 807,765 dozens, valued at $\$ 1,498.675$, or $\$ 1 . \$ 6$ per dozen. They were in many varieties, from the most conmon pressed lamps to those ornately fashioned, and their value was 8.8 per eent of the total value of all pressed and blown ware. By far the largest proportion consisted of the commonest pressed grades. The manufacture was confined to 6 states and 27 establishments, several of whien made a specialty of highly deeorated lamps. The largest factory in the world making deeorated lamps exclusively was located in Yennsylvania. Great progress was made during the last decade in the manufacture of deeorated lamps of a medium grade, and this braneh of the industry is receiring increased attention.

In Pennsylvania 65.6 per cent of the total value and $56 . t$ per eent of the total quantity was manufactured. at an average value of $\$ 2.16$ per dozen. The largest proportion of Ohio's total product was eommon lamps: the quantity manufaetured was 23.7 per cent of the total quantity, and the ralue $12 . t$ per cent of the total value, with an arerage value of 97 cents per dozen. In West Virginia, with the bulk of the production of decorated lamps. 18.t per cent of the total ralue and 7.6 per cent of the total quantity was manufaetured at an arerage value per dozen of $\$ t . t \bar{i}$. The lamps manufaetured in Indiana were largely of a eheap grade: the quantity manufactured was 10.1 per eent of the total quantity, and the ralue 2.9 per cent of the total ralue. at an arerage value of 53 cents per dozen. Lamps were manufaetured also in New York and Massachnsetts, the product of the former state being largely eommon lamps. and that of the latter a better grade of ware.

The use of the tank in lamp manufaeture has made possible a considerable reduction in cost from that of the old pot-melting method whieh was in general use in 1590. The manufacture of pressed lamps has been steadily inereasing, resulting in a large reduetion in the eost of the common artiele.
The value of lamp chimners manufactured in 1900 was $\$ 2,719,583$, the greatest in ralue of any single product reported under the pressed and blown glass branch of the industry. and was 15.9 per cent of the value of all pressed and blown glassware. The manufaeture was reported in 6 states, but 90.4 per eent of the total value of produets was manufactured in Indiana, Pennsylvania, and Ohio. The arerage value per dozen for the United States was 39 eents. Indiana led, with a prodnct eonstituting $45.1 \mathrm{pcr}$ eent of the total quantity and $t \pm$ per eent of the total value, the average value being 38 cents per dozen. Pcmnsylvania was second with 26.6 per cent of the total quantity and 23.5 per cent of the total value, at an average vilue of 35 eents per dozen. The quantity of lamp ehimners manuiaetured in Ohio was 21.9 per eent of the total. and the value 22.9 per eent; the arerage value per dozen was 42 , eents. The remaining states in whieh lamp chimners were manufaetured were Illinois, New York, and Massachusetts. There were 27 establishments engaged in the manufaeture.

A eomparison of the statistics for 1900 with the incomplete statistics for 1890 and 1880 shows how the manufacture of ehimneys has moved westward, following the natural gas and cheap fuel, and also gives some idea of the extent the production has been curtailed by the increased use of gas and electrie light. The total number reported in 1890 was $7,534,473$ dozens, valued at $\$ 1,816,016$, and distributed as follows: Ohio, $4,025,120$ dozens, valued at $\$ 541,836$; Pennsylvania, 2,885,841 dozens, valued at $\$ 1,017,639$; New York, 623,512 dozens, valued at $\$ 256,5 \pm 1$. In 1880 the total number reported for the United States, no value being given, was $4,463,140$ dozens, distributed as follows: Pennsylvania, 2,719,649 dozens; New York, 8s8,639 dozens; Ohio. $i t 3,1$ to dozens: and Massaehusetts. 111.712 dozens. No lamp ehimneys were reported as manufactured in Indiana in either 1880 or 1890 ; this state was first, however, in 1900 in this branch of the industry, and suceeeded Ohio, whieh was the leading state in 1890. This change in the relative positions of these two states was eoineident with a similar ehange in the supply of natural gas. A decrease of $8 . t$ per eent in the total quantity manufaetured in the United States is shown from 1890 to 1900, while the total value in 1900 exceeds: that of 1890 by 49.8 per eent; this was due largely to the extremely low ralue reported for the product of Ohio in 1890, whieh was more than one-half of the total quantity reported at that time.

During the last decade the improvement in the manufacture of lamp chimneys was shown by better quality and a greater variety of design. There has been a large increase in the use of higher grade ehimners of speeial design. Special attention has been given to the paekage for fine grade ware, and a large number of such ehimneys have, within the last few years, been paeked in separate cartons. resulting in a deeided improvement in appearanee and in safety of shipment. 
The manufacture of lamp chimneys by the blowing machine was limited to two factories in 1900 , and in only one of these plants was it carried on extensively, being confined largely to a cheap class of goods. Machine-blown lamp chimners will probably represent a large proportion of the production in the near future, although it is questioned if the higher grades of chimneys will not require hand work. During 1900 the lamp ehimnes market was fairly well regulated by an agreement between the largest manufacturing interests, but a number of small establishments in Indiana were causing demoralization in lime glass ehimneys, or the cheap grade of goods. During the census year the tank furnace became a factor in the manufacture of the common lime glass chimners, $t$ tanks being reported. Great strides had also been taken toward improved factory equipment for handling the ware; lehrs operated by electricity, electric conveyors to take the ware from the lehr to the packer and then to the - stock room or car. were among the improvements made, together with a great increase in the rapidity of the finishing operation. A good export trade has been dereloped in this brauch of the industry. Large shipments have been made for many years by export houses, but during the census year the manufacturers renewed attempts to reach the export trade direet, and a special effort to introduce the American lamp chimney into England was successful, 66,667 dozen chimneys being reported as sent direct from factory to England during the year. The remainder of the exports that were shipped direet from the factories were sent to South Ameriea and Mexico.

Lantern globes were manufactured during the census year in 6 states by 27 establishments, and the number reported was $1,044,816$ dozens. valued at $\$ 497,021$, or 2.9 per cent of the total value of all pressed and blown ware manufactured. The arerage value per dozen was 48 cents, the arerage value by states ranging from 25 cents to $\$ 1.17$ per dozen, depending upon the quality of the ware. There were two establishuents employed exclusively in the manufacture of lantern globes, one in Indiana and one in IVest Virginia. The percentages of the produet manufactured in the leading states, of the total for the United States, are as follows: Indiana, 52.4 per cent of the quantity and 35.4 per cent of the value, with an arerage value per dozen of 32 cents; New York, 15.5 per cent of the quantity and 38.2 per cent of the value, with an average ralue per dozen of \$1.17; Ohio, 13.7 per cent of the quantity and 14 per cent of the value, with an average value per dozen of 4. cents: West Virginia, 12.6 per cent of the quantity and 6.6 per cent of the value, with an average value per dozen of 25 cents; Pennsylvania, 5.6 per cent of the quantity and $5 . \pm$ per cent of the ralue, with an arerage value per dozen of 46 cents. A small proportion was manufactured also in Massachusetts. Indiana and West Virginia supplied the great bulk of the out- put of cheap lantern globes, while New York led in the manufacture of ware of a higher grade. There were no statistics of the manufacture publisher at the census: of 1890 , but a great increase has been made during the decade. During the census year rery active competition on the cheaper grades of lantern globes was developed. More than 10,000 dozen lantern globes were reported in 1900 as exported direct from the factories to Mexico and Central America: this represented but a small part of the total exportation.

The manufacture of pressed and blown shades, globes. electric bulbs, and glassware for gas and electric lighting ranked third in ralue of produets in the pressed and blown ware branch of the industry in 1900 . being 14,6 per cent of the total. The shades and globes ranged in quality from the plain pressed Welsbach gas article to the most costly and artistic products in fine plain and colored glass. richly decorated, engrared, or etched. The manufacture of glassware for the Welsbach gas light had dereloped to a rery large extent. Electric glassware, such as incandescent bulbs and arc globes, formed a large item, although foreign competition in that line was quite active. The manufacture of gas and electric glassware has been largely a derelopment of the last decade, and it is now one of the specialized lines of the industry. Although the increased use of gas and eleetricity has curtailed the use of the oil lamp in some quarters, yet a tendency has been shown toward the use of fancy lamps with highly decorated or ornamented shades and globes, more for decolative effect. probably, than real use, and this has greatly stimulated the production of globes and shades of a much higher quality in general than was ever before manufactured. The total production of shades, globes, and gas and electric goods in 1900 was manufactured in 7 states. from 3 of which, Pemsylvania, New York, and Ohio. 44.9 per cent of the total value was reported. There were 30 establishments engaged in the manufacture of these goods on a more or less extensive scale. The arerage value per dozen for the United States was 93 cents. the average value by states rarying as the bulk of the output was cheap gas and electrie ware or decorated shades and globes.

Froru Pennsylvania was reported 32 per cent of the total quantity and 58.1 per cent of the total ralue, the arerage value per dozen being $\$ 1.70$. Large quantities of medium-priced globes and shades, cheap gas goods. and a valuable production of globes and sliades of the finest quality were manufactured in that state. In New York a large quantity of high-grade shades and globes, and a large output of eleetric bulbs were manufactured. The quantity of articles of this class manufactured was 11.7 per cent of the total, and the ralue 20.8 per cent, with an arerage value per dozen of $81.6 t^{\circ}$. A large number of electrie bulbs was manufactured in Ohio, which was third in rank as to value of products. but was far in the lead as to quantity, with 5.2 .3 per cent 
of the total quantity reported and 16 per cent of the total ralue, the arelage ralne per dozen for the state being $2 S$ cents. Shades, globes. and gas and clectric goods were llanufactuled also in Mcst Tilginia. Massachusetts. Indiana. and $\mathrm{New}$.Jersey. Decorated shades and glohes constituted the larger part of the product in IVest Virginia. and the produet in Indiana was electric and gas wale. at an avelage ralue of 13 eents a dozen. Shades and globes rerc manufaetured in Massachusetts. and in Tew Jersey the prodnet was entilely electric bulbs. Great improrements have been made in the last few rears in the package for shades and globes, nearly all the better grade being packed in separate cartons. The cxport trade has had a steady growth, but complete statistics werc not obtained trom the factories. A total of 41.200 dozen articles in this branch of the industry, mostly elcetric ware. Was reported in 1900 as shipped dircet from the factories to Canada, the West Indies, South America. and Australia. By far the largest proportion Was exported to Canada.

Blown tumblers, stemware, and bar glasses, $6,127,367$ dozen in number, were reported in 1900 br 17 establishments in 4 states. These produets constituted $9 . \pm$ per cent of the ralue of all pressed and blown ware manufactured. The arerage ralne per dozen for the United States was 26 cents. The manufacture of this class of ware has become greatly concentrated, 94.3 per cent of the total ralue of products being reported from Pennsylrania and West Virginia. The pereentages of the total quantity and total ralue manufactured in the two leading states are as tollows: Pennsylrania. 57.3 per cent of the quantity and 69.3 per cent of the ralue, with an arelage value of 31 cents per dozen: West Virginia, $3 \pi . t$ per cent of the quantity and 25 per cent of the ralne. with an arelage value of 17 cents per dozen. The remainder of the product was manufactured in Ohio and Indiana, the arelage ralue per dozen in Ohio being 25 cents. and in Indiana, $3 \pm$ cents. The returns do not embrace the total production of blown tumblers, as many were reported nnder "cnt glass," haring receired light cutting. A large proportion of the lower grade of blown tumblers manufactured in Pennsrlvania was made on the blowing machine. but practically all the finer grades were made by hand. Great improrements in the finishing of this class of ware have been made in the last few years, and mueh of the "crackingoft" is done by a machine on which a gas jet is nsed in place of a wire, one machine, operated by a boy: having a capacity of 9.000 tumbler's a day. Improrements in grinding machiners hare made it possible for two girls with one machine to grind 22.500 dozen tumbler's in a week. For a long period blown tumblers. stemmare, and bar goods hare formed a large item in glass exports. being shipped to the principal conntries of the world in steadily increasing quautities.

Decorated opal or poreelain glassmare was rerg much in faror with the public during the closing years of the last decade. It was made into small-piece sets, in an cndless rariety of norelties and toilet alticles. In 1900 the manufacture of $3.750, \pm \pm 3$ dozen pieces was reported. replesenting 4.3 per cent of the total ralne of pressed and blown glassware manufactured. In liare part the decolations wele of the cherpest kind, the arerage price per dozen for the United States being 12 cents. Trenty-six establishments in 6 states reported it - manufacture. and 90.7 pel cent of the total ralne of the produets was made in Pennsylyania and West Virginia. Establishments in Pennsyrania made 78 per cent of the total quantity and 76.8 per cent of the total ralue, and in Test Virginia 12.8 per cent of the total quantity and 13.9 per cent of the total ralue. Establishments in Indiana. Ohio, Massachusetts, and New York were engaged also in manufacturing this class of ware. The great demand for decorated opal or porcelain glassware developed within the last half of the decade. and in 1900 its manufacturc formed a prominent part in the operations of some of the largest pressed ware establishments in the country, leading to a large inerease in the dee-. orating facilities of those plants. The craze for opal warc was deercasing at the close of the census year and the production gave eridence of soon returning to normal proportions.

Cnt glassware, 134,726 dozen pieces in number, valued at \$672.463, an arelage of \$ $\$ .99$ a dozen, was reported by 12 estahlishments in 1900. 'This report does not corer the numerons glass-cutting establishments in which the basic material used is the glass blank and in which the manufacture consists merely in ireworking the glass. A large portion of the cut glass leported from Pennsylrania and West Virginia was light-cut articles, such as tumblers, althongh there was 1 establishment in Pennsylrania engaged largely in the manufacture of cut ware of the highest grade. The pelcentages of the total quantity and total ralue manufactured in the sereral states are as follors: Pennsylrania, 42.2 per cent of the total quantity and 46.3 per cent of the total valne, at an arelage value of $\$ 5.48 \mathrm{pel}$ dozen pieces: Massachnsetts, only 2.5 per cent of the total quantity but 21.8 per cent of the total valne. the arerage value of $8 \pm 1$ per dozen indieating the manufactnre of the richest cut ware; the same is true of Ohio, with only 2.2 per cent of the total quantity and 18.7 pel cent of the total ralue, an arelage ralue per dozen of \$43.45. In West Virginia, with its large prodnction of blown ware. practically all light cutting was done, the product areraging $\$ 1.23$ per dozen in ralue; the plodnet of that state was 23 per cent of the total quantity. but only 13.1 pel cent of the total ralue.

West Tirginia was first in the number of pieces manufactnied. although its product mas practically all of the cheapest kind. A small product was also reported from Indiana. The largest part of the cut glass manufactnred was made in establishments in which the glass was re- 
Forked only, and is not included in this report. A list of such establishments. published at the close of the census rear, giving the number in each state, was as follows: New York, 21; Pennsylyania, 13; Illinois, 4; Connecticut, 2: and Massachusetts, Rhode Island, New Jersey. West Virginia, and Michigan, 1 cach. The industry has had a large growth in the last decade, particularly during the latter part of it, the number of establishmeuts having doubled and the number of frames operated more than trebled. The dcmand has steadily increased and the market widened as prices hare been lowered by competition. The popularity of pressed ware in imitation of cut ware shows the ridespread desire for the real cut article. An improrement that will probably be made in the industry is the manufacture of the blank by pressing, increasing the speed of manufacture fourfold over the blowing process. It was for a long time the practice to import the blanks from France for most of the finest grade of ware cut in this country, but the domestic blank is now conceded by competent judges to be equal, if not superior. and is steadily supplanting the imported article. The superiority of American rich cut glass is generally acknowledged at home and abroad.

The amount reported as the ralue of all other pressed and blown trare products. $\$ 1.38 t, 945$, includes a large rariety of articles for different purposes. Onc item that has come into prominence during the last few rears is the manufacture of prismatic glass for increasing the diffusion of sunlight in buildings. The product of the only establishment manufacturing glass play marbles in the United States, located in Ohio, is included in this total.

The value of all products other than glass reported by establishments manufacturing pressed and blown ware and bottles and jars was $\$ 690.562$, a large item being packages, particularly for lamp chimneys. According to some manufacturers, the profit in certain lines of chimneys lies entirely in the sale of the package.

\section{MATERIALS.}

Table 10 is a comparative summary of the quantity and cost of the materials used, with percentages of in crease, for 1890 and 1900 .

TABLE 10.-QUANTITY AND COST OF MATERIALS USED, 1890 AND 1900, WITH PER CENT OF INCREASE.

\begin{tabular}{|c|c|c|c|c|}
\hline & 1900 & 1490 & Increase. & $\begin{array}{c}\text { Per } \\
\text { cent } \\
\text { of in- } \\
\text { crease. }\end{array}$ \\
\hline 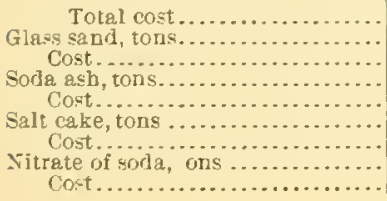 & $\begin{array}{r}\$ 16,731,009 \\
581,720 \\
\$ 846,822 \\
157,779 \\
82,259,939 \\
53,257 \\
\$ 518,590 \\
10,770 \\
\$ 320,937\end{array}$ & $\begin{array}{r}\$ 12,140,983 \\
369,328 \\
\$ 899,998 \\
96,777 \\
\$ 3,108,233 \\
38,092 \\
\$ 604,179 \\
7,031 \\
\$ 278,291\end{array}$ & $\begin{array}{r}\$ 1,590,024 \\
212,392 \\
1 \$ 53,176 \\
61,002 \\
1 \$ 818,291 \\
15,165 \\
1 \$ 85,589 \\
3,739 \\
842,646\end{array}$ & $\begin{array}{r}37.8 \\
57.5 \\
15.9 \\
63.0 \\
127.3 \\
39.8 \\
{ }^{1} 14.2 \\
53.2 \\
15.3\end{array}$ \\
\hline
\end{tabular}

TABLE 10.-QUANTITY AND COST OF IJATELIALS USED, 1890 AND 1900, WITH PEI CENT OF INCIEASE-Con.

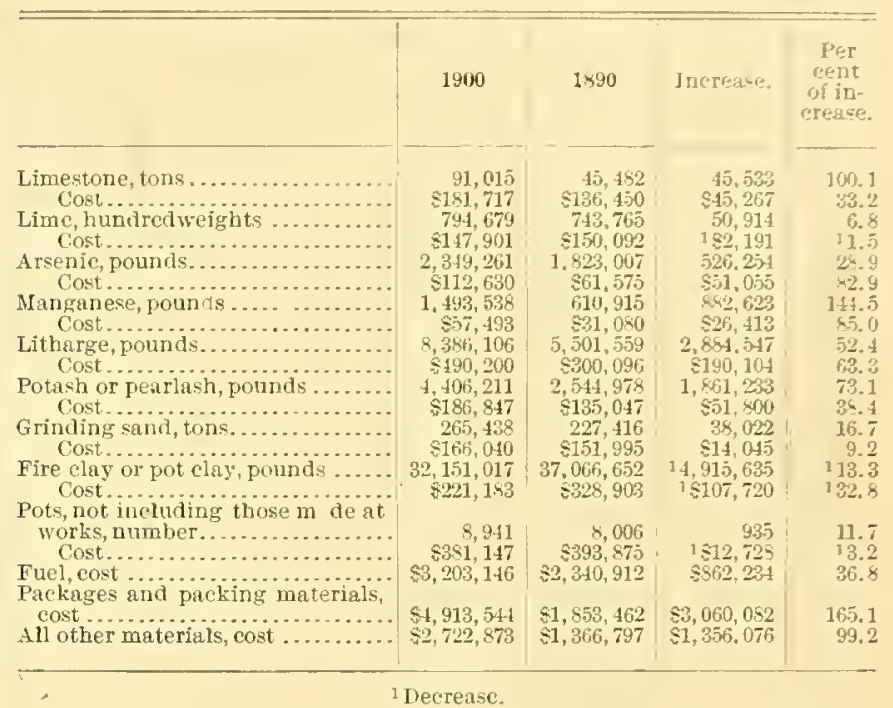

The cost of materials used in the combined industry of glass manufacture in 1900 was 37.8 per cent greater than in 1890. In nearly all the principal materials; a comparison of returns for 1900 with those for 1890 shows a large increase in the quantity used and a decided decrease in the average cost per unit. notwithstanding the fact that in 1900 the prices of practically all glass-making materials were sharply advanced. An increase of 57.5 per cent is shown in the total number of tons of glass-melting sand reported used in 1900 orer $1890,581,720$ tons being reported in 1900 and 369.325 in 1890 . On the other hand, a decrease of 5.9 per cent in total cost is shown in 1900 from 1890. the total cost in 1890 being $\$ \$ 99,998$, while in 1900 the total cost mas $\$ \$ 46, \$ 22$. The average cost per ton in 1900 mas $\$ 1.46$ compared with $\$ 2.44$ in 1890. Glass sand of rery fine quality in practically inexhaustible supplies, is found in many parts of the country, although the chief sources of supply are still, as they have been for many years, the Juniata Valley in Pennsylrania; Hancock county, West Virginia; the Fox River district in Illinois: and St. Charles, St. Louis, and Jefferson counties in Missouri. By far the largest proportion of the glass sand used comes from these deposits, although southern New Jersey still furnishes sand for a number of factories in the East, and sand of the finest quality still comes form Berkshire, Mass. The cost of transportation aud the fine quality of more available deposits hare considerably restricted the output from the latter locality. During the census year a considerable quantity of good glass sand came from Westmoreland county. Pennsrlrania.

The preparation of sand for the glass factories became a highly specialized business during the last decade. about a score of establishments being exclusively engaged in the industry, with elaborately equipped plants representing large investments. The actire competition which developed among these establishments is 
principally accomtahle for the large decrease in price in 1900 compared with $18: 0$. Eight establishments in the Juniata Viller were merged under one head during the census reatr and prices on all grades of sand were sharply raised. Many glass manufacturers, however, had contracted tor their supply tor the season during the period of low prices, and, in addition, two of the largest manufacturing interests were mining and preparing their own sand to a large extent, making it cost them considerably below the arerage. Competition has led to the greatcst care and attention in the preparation of the glass sand and the maintenance of a high quality.

The supply of soda ash for glass manufacture formerly came almost entirely from England; but during the last decade, through the development of the Solvay process. practically all soda ash used in glass making was of domestic manutacture, coming mainly trom Syracuse. N. Y., and near Detroit, Mich. A large plant was projected during the census year at Barberton, Ohio. by glass manufacturing interests. One of the greatest adrances in the domestic manufacture of soda ash was the establishment dnring the decade of large works at Wrandotte, Nich., by glass manutacturers to directly supply their wants. The number of tons of soda ash reported in 1900 was 157,779 , compared with 96,777 tons in 1890 , an increase of 63 per cent, while the total cost in 1900 was $82,259,939$, compared with $\$ 3,108.233$ in 1890 , a decrease of 27.3 per cent. The a verage cost per ton in 1900 was $\$ 14.32$. compared with $\$ 32.12$ in 1890 . The demand for soda asb in 1900 was unusually large, exhausting the domestic snpply and greatly increasing importations. This abnormal demand came trom outside the glass industry, the textile industry using a large quantity, and is shown by the large increase of importations in 1900 orer 1899 . As reported by the Bureau of Statistics of the Treasury Department. imports entered tor consumption were $\$ 0,118,967$ pounds, valued at $\$ 665.104$. in 1900 , compared with $41 . \$ 44,101$ pounds, valued at $\$ 304.549$. in 1899.

The salt cake used in glass making twenty rears ago was nearly all imported, but the greater portion of the amount consumed in the census rear was of domestic manutacture, many large chcmical manntacturer's turnishing it, to the almost total exclusion of the foreign product. Competition has lowered the arerage cost per ton 38.6 per cent from 1890 to 1900 , the average cost per ton for the respective year's being $\$ 15.86$ and \$9.7t. The number of tons nsed in 1890 was 38,092 . eosting $\$ 604,179$, compared with 53,257 tons in 1900 , costing $\$ 518,590$, an increase in quantity of 39.8 per cent and a deerease in cost of 14.2 per cent.

Practically the entire supply of nitrate of soda used in glass manufacture in the United States comes from South America. The number of tons used in 1890 was 7.031 , costing $\$ 278,291$, compared with 10.770 tons in

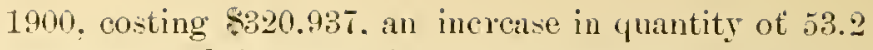
per cent and in cost of 15.3 per cent. In 1890 the areragc price per ton was $\$ 39.58$. compared witl $\$ 29 . \dot{8} 0$ in 1900 .

The number of tons of linestone used in glass manufacture in 1900 was 41.015 , costing \$181.717, or an arerage of 52 per ton, compared with 45.482 tons in 1890 , costing $\$ 136.450$, or an a verage cost of $\$ 3$ per ton. The increasc in the quantity used in 1900 over 1890 was 100.1 per cent, and in cost 33.2 per cent. Olio and Indiana were the principal sources of supply.

The quantity of lime used in 1900 was 794,679 humdredweight, costing \$147.901, compared with 743,765 hundredweight in 1890 . costing $\$ 150.092$, an nucrease in 1900 over 1890 of 6.8 per cent in quantity and 1.5 per cent in cost. The average cost per hundredweight in 1890 was 20.2 cents, and in 1900 was 18.5 cents. Mnch of the lime is wood-bmed and ground and bolted, the industry being highly dereloped in Seneca county. Ohio, and ricinity.

England has been the chief source of the supply of arsenic used in glass manufacture. Recently, howcrer, the imports from that country have been greatly reduced br the supply from the gold fields of Britis: Columbia. At the close of the census year, movements were in progress which promised to result in the development of the mannfacture in this country, and it is confidently asserted that in a few years the glass industry will be supplied cntirely by arsenic of domestic manufacture. In $1890,1,823,007$ pounds were reported, costing $\$ 61,575$, and in $1900,2,349,261$ pounds, costino $\$ 112,630$, an increase of 28.9 per cent in the quantity and 82.9 per cent in the cost.

Manganesc. which comes largely from Saxony, was used in 1890 in glass making to the extent of 610,915 pounds, costing $\$ 31,080$. compared with $1,498,538$ pounds in 1900 , costing $\$ 57,493$, an increase in quantity of 144.5 per cent and in cost of 85 per cent. The arerage price per pound was 5.1 cents in 1590 and 3.2 cents in 1900 .

The proportion of litharge manufactured in the United States for use in glass manutacture is stcadily increasing, but a large proportion is still imported from England. The quantity used in 1890 was $5.501,559$ pounds, costing $\$ 300,096$, compared with $8,386,106$ in 1900 . costing $\$ 490,200$, an increase in quantity of 52.4 per cent and in cost of 63.3 per cent. The average cost

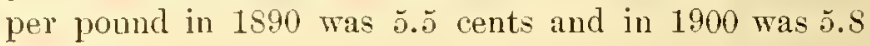
cents.

There were 2,544,97s pounds of potash or pearlash, which was supplied principally from Germany, used in 1890, costing $\$ 135,047$, compared with $4,406,211$ pounds in 1900 . costing $\$ 186,847$, an increase in quantity of 73.1 per cent and in cost of 35.4 per cent. The average cost per pound in 1890 was 5.3 cents and in 1900 was 4.2 cents.

A notable increase is shown in the consumption of 
packages and packing materials in 1900 over 1890 . The cost of such materials in 1890 was $\$ 1, \$ 53,462$ compared with $\$ 1,913.544$ in 1900 . an increasc of 165.1 per cent. The neatness of the package receired special attention during the latter part of the decade, and great improve- ment has resulted, compared with the practice followerl formerly.

$$
\text { IMPORTS ANI) EXPORTS OF GLASN. }
$$

Table 11 presents the valuc of the different kinds of glass imported and exported from 1869 to $190 \%$. inclusive.

TABLE 11.-VALUE OF GLASS IMPORTED AND EXPORTED: 1869 TO $1900 .{ }^{2}$

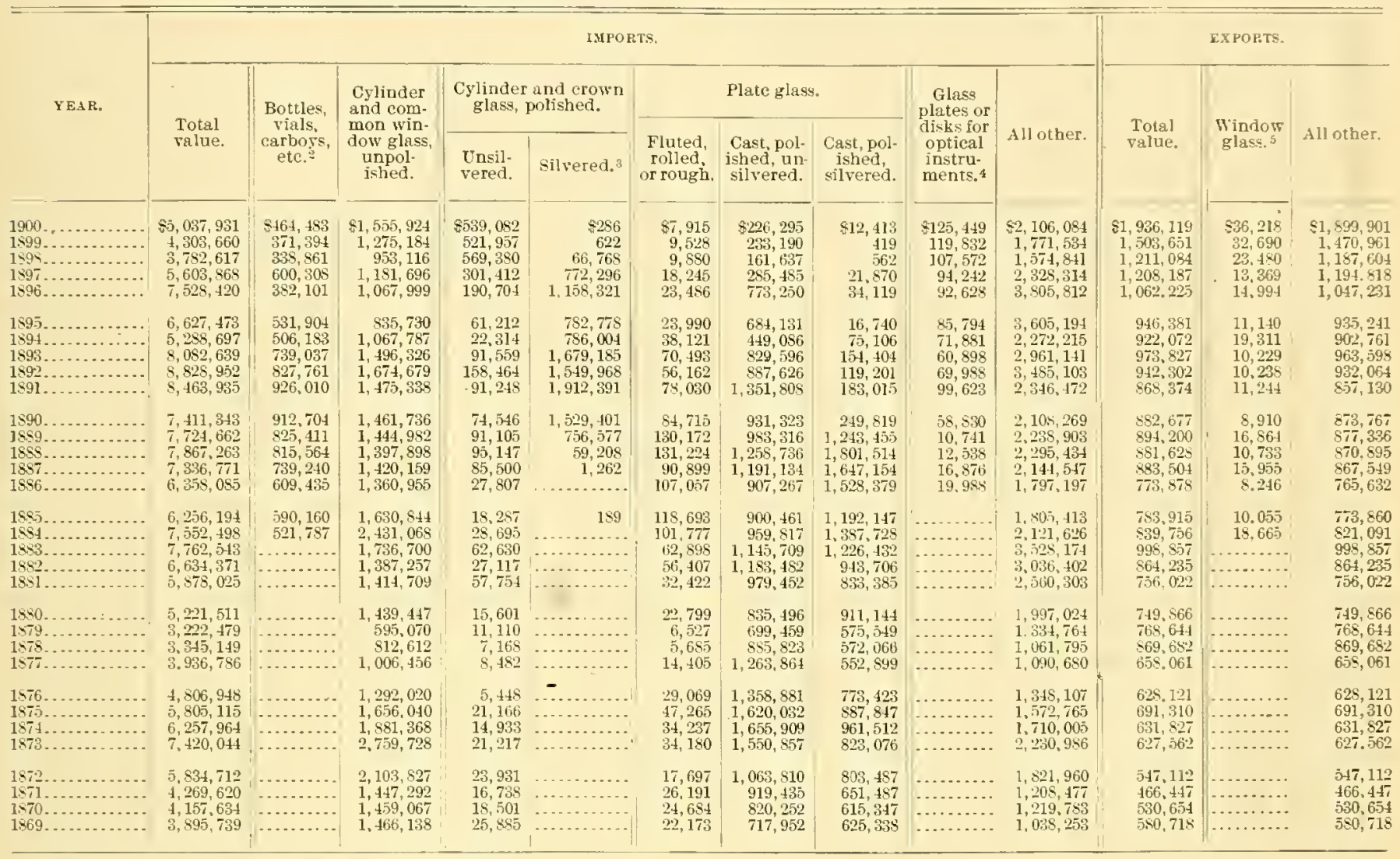

1 Reports of United States Treasury, Bureau of Statistics

"Included in "all other" glass and glassware imported previous to 1 is

"Included in " unsilvered exlinder and erown glass, polished " previous to 1,455

"Intupled in " all other" prasions 185

The import figures presented in Table 11 for "cylinder and crown glass, polished," and plate glass, silvered and unsilvered, show the great victory the American manufacturers of polished plate glass have gained in superseding the foreign article, particularly the forcign mirror plate, br glass of domestic manufacture. The silvered, polished crown glass is styled German lookingglass plate, while the silvered polished plate glass is what is commonly known as French mirror plate. The German plate is lighter and inferior to the French plate and is nearly all imported under 5 square feet in dimensions, while the French plate is of larger sizes. From 1869 to 1859. inclusive, the value of importations of French mirror plate was nearly equal to the imports of polished plate glass unsilvered, the aggregate value of the Frencn mirror plate during the twent $y$-one years being $\$ 20,557,075$ while the ralue of the unsilvered polished plate was $\$ 22,901.144$. Previous to 1885 the importations of the German mirror plate are included in the table with the unsilvered polished crlinder and crown glass, the larger part of the polished crlinder and crown inported to that date being emplosed for car windows and similar uscs where a glass thinner than ordinary plate and of better quality than common window glass was desired. The importations of silrered German mirror plate prerious to 1889 were inconsiderable. but in that year their value increased from 859.208 in 1888 to $\$ 756.576$. or 1.177 .8 per cent.

The year 1889 milled the beginning of the decline of the importations of Frencl nirror plate and the growth of the importations of German plate. The ralue of imported French silvered plate in 1890 was only $\$ 249.819$, a decrease of 79.9 per cent from the previous year: this was due in part to the introduction of American plate. but more to the remarkable. increasc in importations of the cheaper German plate. 
The ralue of the German silvered plate inported in the same rear increased sit2.824, or 102.2 per cent over 1889, For the next seven years. German silvered plate importations exceeded in value the combined value of silvered and unsilvered polished or French plate. The plate glass manufacturers of the United States during this time were direeting their competition against the more profitable field filled by the French silvered and unsilvered plate, so that the German plate had nearly a clear field. Howerer, an increase of plate glass productive capacity in the United States in 1894 produced a period of low prices that caused large reductions in the value and number of square feet of all foreign plate imports, reducing the ralue of-inported French mirror plate $51 . t$ per cent from 1893 to 1894; German silvered plate 58.2 per cent; polished plate and rough plate, each $45 . \pm$ per cent; and unsilvered polished cylinder and crown glass 75.6 per cent. From this period of low prices a better organization of the American plate glass manufacture developed, a consolidation of individual companies controlling a large percentage of the capacity being formed; and the fight against foreign glass was carried on so successfully that from $189 \pm$ French mirror imports have dwindled to insignificant proportions, being, in $1900,83.5$ per cent less than in 1594 and 95 per cent less than in 1890. During 1895 and 1896 imports of polished plate, unsilvered, increased to somc extent, eaused largely by the sale in the United States at low prices of surplus foreign stoek. After 1896, however, the American manufacturing interests lined up more closely against the foreign trade, and since then the value of imported polished plate has been gratifyingly small, showing in 1900 a decrease of $70 . \pm$ per cent from 1896 and 79.5 per cent under the total value of 1890 .

While German mirror import ralucs reeeived a decided cheek in 1894 and 1895 , the next two years witnessed a reviral and a change in the form of impoltation, an inereased quantity being imported unsilvered, to be silvered by American mirror makers. Table 11 shows a marked decrease in the valuc of silvered Gerinan plate imports in 1897 and a considerable increase in the unsilvered imports. American competition has made it advantageous to have the silvering done in this country. With French mirror plate practically excluded, the plate-glass manufacturers of the United States took up the German mirror plate problem, and by selling superior polished plate to the mirror trade at cost, or less, reduced the value of German plate imports, unsilvered and silvered, nearly one-half in 1897 , and at present have stopped the importation of the German silvered plate even more completely than they have the French product. In 1900 practically all the German plate was imported unsilvered, and was much less than the total quantity, silvered and unsilvered, annually imported from 1890 to 1897.

A portion of the imported polished cylinder and crown glass comes in competition with domestic window glass for car windows, but the expected derelopment of the manufacture of thin polished plate glass in this country may probably supplant the foreign artiele for high-quality and light-weight glazing purposes. Ninetyfire and five-tenths per cent of the total quantity of unsilvered polished cylinder and crown glass imported in 1900 was shipped fron Germany, the remainder being dirided anong Austria-Hungary, Belgium, France, Netherlands, and the United Kingdom. Of the total quantity of fluted, rolled, and rough platc imported in 1900, the United Kingdom supplied 91.3 per cent and France, Belgium, and Germany, the remainder. The importation of polished plate glass is controlled by an European syndicate, and is apportioned among the various producing countries; Belgium furnishing, in 1900 , 80.2 per cent of the total quaritity; Germany, 8.1 per cent; and the United Kingdom and France, practically all the remainder. The extent of the importation is determined largely by trade conditions abroad, this market being used for the disposal of surplus products, with slight regard to price. New York is the principal port of cntry for plate glass.

The ralue of importations of fluted, rolled, and rough plate has steadily dccreased, being, in 1900, 90.7 per cent less than in 1590 . The total value of such imports in 1900 was nearly equaled by the direct export shipments of one American skylight factory.

Window glass importation values have maintained comparative regularity during the last thirty years. The total value of window glass imported during the deeade ending with 1880 was $\$ 14,993,860$; from 1880 to $1890, \$ 15,686,308$; and from 1890 to 1900 the value was $\$ 12,583,779$. While the total value of window glass imported during the last decade was less than that of each of the two preceding deeades, the value in 1900 exceeded that in 1890 by $6 . t$ per cent; 1880 by 8.1 per cent; and 1870 , by 6.6 per cent. The number of pounds imported in 1900, as reported by the United States Treasury Bureau of Statisties, was 51,343,389, which, estimating 70 pounds to the 50 -foot box, 25 per cent double strength, equals 733.476 boxes, or 16.9 per eent of the quantity manufactured in the United States in that year. The number of pounds imported during each of the preceding ten years was as follows: 1899, $47,202,267 ; 1898,38,908,992 ; 1897,55,961,813 ; 1896$, $53,182,301 ; 1895,40,786,279 ; 1894,52,437,068 ; 1893$, $63,715,989 ; 1892,72,682,127 ; 1891,58,932,738 ; 1890$, $73,112,550$. The imports, $92 . \tau$ per cent of which come from Belgium and the remainder from the United Kingdom, Germany, and France, are regulated largely, as in plate glass, by the condition of the foreign market. The Continental and far Eastern markets are the most profitable fields for Belgian window glass, and if the demand in these markets is weak and a surplus stock accumulates in Belgium, increased shipments to the United States follow. Belgian glass, the product of 
cheaper labor. constantly acts as a check on windowglass prices in the United States, for unless the demand abroad is unusually strong. the first announcement of high prices in this country results in an incrcase of exports. The foreign window glass, as in the case of plate glass, was for a long time credited with superior quality, especially as to finish. but in both cases that claim has been disproven in the progress of the American plate and window glass manufacture during the last decade. In 1900 Boston, Mass., was the principal entry port for foreign window glass, followed by New York, N. I. The entrr ports for the South are St. Louis, Mo.; Baltimore, Md.; Newport News, Va.; and New Orleans, La. Prerious to 1901 most of the window glass used on the Pacific coast was of foreign manufacture, entering principally at San Francisco. The cheapness of ballast freight rates of wheat-carrying ships returning to the Pacific coast, compared with the expensive orerland freight rates from the domestic window-glass factories, gare the foreign glass a great adrantage, but American manufacturers, by a decided differential in price and systematic distributing arrangements, have succeeded lately in steadily reducing the importations to that section of the country.

The ralue of imports of bottles, vials, carboys, etc., has shown an almost constant decrease from year to rear during the last ten years. The total value in 1900 wis $\$ 164.483$, or 49.1 per cent less than in 1890 . About one-half of the total importation consists of bottles filled with liquors, mineral watcrs, etc., and the principal exporting countries are Germany, France, AustriaHungary, and the United Kingdom, in the order named. The importation of empty bottles, therefore, is very small in comparison with the domestic output. New York and Baltimore are the chief entry ports, but many unfilled bottles enter at San Francisco, coming over at cheap rates in returning wheat-carrying ships. Boston, New Orleans, and Philadelphia, also have large receipts.

The importation of optical glass has steadily increased, the development of the photographic camera being a strong stimulant. A large portion of the total importation enters in the New York camera district at Rochester, N. Y. Germany furnished 43.7 per cent of the total value in 1900; the United Kingdom, 33.7 pcr cent; and France, 22.6 per cent. Attempts hare been made in this country to inake optical glass, but the manufacture has never passed beyond the experimental stage, and at present even experimenting has ceased. The time and care required and the uncertainty as to results attending every melt, in face of the free entry of these products from countries long skilled in the art, make the manufacture of optical glass an unattractive proposition to glass manufacturers in the United States.

A large proportion of the $\$ 2,106,0 \$ 4$ reported as the value of "all other" glass imports in 1900, was that of fancy decorated Bohemian glassware, much of it made to sell at low prices. The fancy colored and decorated ware, of the Bohemian order, is as yet but a small item in glass manufacture in the Cnited States, although a large quantity is purchased. Increased attention is being given to it, and such success was achiered in its manufacture during the census year by at least one firm, that it will very likely have a vigorous growth during the next few years. Decorated opal or porcelain glass has met with great favor in this country for several ycars, and in addition to the large quantitr of home manufacturc, a considerable quantity has been imported, mostly from Germany. Germany has a large trade in chemical glassware for laboratory use, and, with England and France, is finding a rich and almost undisputed field here for that class of ware. The manufacture of chemical ware has been carried on in the United States in a small war, but a recent movement among Ameriean chemists in faror of home manufacture has caused more or less agitation among glass manufacturer's, and gives promise of leading to a determined attempt on the part of one or two firms. to establish the industry on a larger scale in this countr.

Great progress has been made in recent years in the manufacture of expensive "art glass" of the highest order. One of the exhibits which attracted considerable attention from glass men of all countries at the Paris Exposition was a new art glass manufactured by a firm in New York city. High-grade lamps. unsurpassed by any manufactured, have been produced in this country. Watch crystals, which are not manufactured in the United States, although it was attempted recently in West Virginia, are imported in large numbers of small aggregate value. The process of manufacture is sinple, and it will in time probably form a part of the American industry. A thin round ball or bubble of glass is blown, and from this. with diamondpointed compasses, the circular disks are cut, which are then placed on properly shaped blocks and bent to the required shape by reheating. Of the total value of "all other" glass imports, 33 per cent comes from Germany, 28.1 per cent from Austria-Hungary. 23.1 per cent from France, 7.8 per cent from the United Kingdom, and 6.8 per cent from Belgium.

Table 11 presents, in addition to the value of imported glass, the value of glass of domestic manufacture exported annually, from 1869 to 1900, inclusive.

The exportation of all other than window glass has almost constantly increased from year to year since 1869. gaining 227.2 per cent in value during that period. and 117.4 per cent during the last decade. The gain in the ten years ending with 1890 orer the ten preceding years was $\$ 1,830,612$, and between 1890 and 1900 orer the ten prcceding years, \$2.922,065. American glassware is exported to nearly every civilized country. is countries being reported by the Bureau of Statistics of the Trcasurr Department in 1900 . Canada receired 30 per cent of the total ralne in 1900: Mexico. 14.6 per cent; Australia, 12.S per cent: Cuba. S.2 per cent: 
and the Cnited Kingdom. $T .3$ per cent. An inquiry as to exports was incorporated in the schedule used for the purpose of eliciting complete information as to the articles exported and their destina tions; but as the largest part of the exporting is done through regular exporting houses, a rery small portion goes direct from the factors with its destination known. The returns from factories. therefore, are rery meager. but as far as they go, furnish an idea of the comprehensive scope of the glass export business. Beer and soda bottles, and plain and lettered prescription bottles. pressed tableware, lamp chimneys, and lantern globes constitute the bulk of the exports reported direct from factories. Bottles to the value of $\$ 161.300$ werc reported as exported during the census rear by 12 firms, $\$ 66.333$ of which was the ralue of beer and soda-water bottles exported to Mexico. where a fair trade has been dereloped recently in that line of ware. Plain and lettered prescription bottles are a large item in the exports, and 6 firms reported direct shipments to Canada, South and Central America. Mexico, West Indies, Great Britain, France. East Indies. Australia. China, and Japan. The bottle trade with the Philippines and Cuba is rers large, principally in the form of bottles filled with beer and liquor. Direct tableware exports were reported by 16 establishments, amounting to $\$ 137,982$.

American pressed tableware is unexcelled in the markets of the world for color, workmanship, and finish. which make it the closest imitation of real cut ware. at such prices as. quality considered, place it in a class by itself. Export trade is receiring special consideration from some of the largest manufacturers of pressed ware, and the American sample room and trareling agent for pressed glassware are becoming more general abroad. The largest part of the lamp chimney exportation is done by jobbing houses, ret $t$ factories reported direct shipments valued at $\$ 111,560$. About four-fifths of the quantity reported went to South America. wherc lamp chimners made in the United States are in high faror. As a result of a recent srstematic introduction of the American lamp chimney in England and some of the continental countries, the exports in that direction are steadily increasing and hare already reached a rery satisfactory figure. American lantern globes are largely used in Central and South America. Canada, South America. and Australia are steadil T increasing their consumption of American gas and electric glassware, such as globes and shades. Cathedral or opalescent glass ralued at $\$ 13,432$ was reported as shipped direct from factory to Canada. Germanr, England, and France. where. by reason of its superior colors and texture, it is preferred in the construction of art windows.

Exports of window glass show some increase during the last few rears. but the lower cost of production in Belgium will, no doubt, continue to restrict, as in the past, the foreign trade of the L'nited States in this commoditr. The exports are contined largely to Mexico, British Ameriea. and the West Indies. A plan has been discussed to operate the American window factol'ies an extra time during the year at reduccd wages to manufacture glass for export exclusirely, but it has not met with faror from the workmen and from some of the manufacturers.

\section{FURAACE IMPROTEMENT.}

The greatest advance madc in the American glass industry in the past decade has been in the improvement of the melting furnace in the direction of greater economy and rapidity in operation. The great feature of this derelopment has been the widespread substitution of the tank for the pot furnace, 48.8 per cent of the total melting capacity of active plants reported during the census year being contained in tank furnaces. In the United States the tank is practically a creation of the last ten years, its standing prior to that time being experimental. though it had been used successfully abroad for a much longer period. So far Germany and Belgium have set the pace for American glass furnace construction.

The glass-melting furnace is a modification of the reverberatory furnace, the materials to be melted being exposed to the action of the flame. but not to the contact of the burning fuel. While numerous modifications exist. the furnaces generally used are of two styles. the pot furnace and the tank furnace. The former is adapted either for the use of open pots or for corered pots, and the latter is either a day tank. intermittent in its melting action. or a continuous tank in which the melting is continuous. The pot furnace contains a number of melting pots, large clay crucibles, each holding. on an average, a ton of molten glass. Thesc pots are arranged immediately inside the breast wall of the furnace with room in the center of the fur. nace for combustion space. The batch, or mixture of the raw materials. is filled into these pots through an opening in the side of the furnace opposite each pot, and after the melting process is completed, the glass is gathered from the pots through these openings. The pot furnace used in the manufacture of plate glass is an exception in this respect. as the pots are remored bodily from the furnace by a crane and their contents poured on the casting table. In the tank furnace, pots are entirely dispensed with, the glass being melted and held on the hearth of the furnace itself, the flame sweeping across its surface. In the continuous tank there is a supply of molten glass at all times, the batch being filled in at one end and the glass worked out continuously at the other end. The dar tank requires a night or day to melt the glass, when it is worked out and the tank again filled with the batch, the operation being similar to the working of a pot furnace. The pot furnaces used in the manufacture of window glass. 
plate glass, and botties and jars are either square or oblong in form, and those for thint glass, tableware, etc., are round or oral.

The open-pot furmace for window glass and bottles and jars raries in length according to the number of pots used, its width being about three times the diameter of the pot. The pots vary in number from 4 to 12 , generally being 6 or 10, placed in the furnace in 2 rows. Openings at the ends of the furnace permit the lemoral and replacement of broken pots. The crown of the furnace, forming the top of the combustion chamber, is preferably rather flat, but set high enough to allow adequate fame development and good distribution of the heat between and above the pots. In the direct-fired furnace, the fuel is on a grate set in the space between the 2 rows of pots. somewhat below the level of the bench on which the pots are placed. An arched passage-the cave-runs beneath the furnace for the admission of air to the grate, and therc are frequently 2 cares crossing at right angles, so as to admit air from all directions. Neither flues nor regenerators are used when the fuel is fired direct, the draft being regulated $b y$ the height of the stack of the furnace, which raries with different fuels employed. In the regenerative gas-fired furnace, the regenerators are so placed that in the erent of a pot breaking, the molten glass can not reach them and ohstruct the draft. The hot eseaping gases from combustion pass from the combustion chamber through the checkerwork of brieks. which take up their heat and soon become very hot. The direction of the flame is reversed and the air for combustion enters through the hot regenerator, while the waste gases pass out through another regenerator. $\mathrm{By}$ a reversal of the direction of the flame erery twenty or thirty minutes, the hot outgoing waste gases are constantly giving off their heat to the regenerators and the incoming air is constantly returning it to the furnace. In what is styled a recuperative gasfired furnace, no reversal of the current occurs. The waste gases pass out through a series of thin-walled flues, while the incoming air is admitted through a second series of thin-walled flues, and coming in contact with the first series of flues, alsorls the waste heat. In the gas-fired furnace the air and gas tlues rise vertically at either end and terminate in ports at or below the hearth level. The flame traverses the furnaee from one end to the other, deseribing the arc of a circle, or by lessening the draft, it can bc made to completely fill the furnace. The open-pot furnace for plate glass is longer than that for window or bottle glass, as it usually holds 20 large pots. There is an opening in the wall of the furnaee opposite each pot to allow its remoral. bodily, for casting purposes. All plate-glass furnaces are gas fired, the air and gas thes ascending and terminating vertically or coming up vertically and turning so as to enter the furnace horizontally. With the use of the lehr in plate-glass manufacture. the ten- dency is now toward smaller pots, which increases the number that may be placed in the furuace.

The covered pot furnace for flint glass is generally circular in form. The pots hare a hood-like top. which projects to the opcning in the breast wall of the furnace and through which the batch is filled in and the glass worked out. This hooded top entirely shields the contents of the pot from the flame. When old or broken pots are to be replaced, the wall of the furnace is removed enough to allow for the passage of the pot. The average life of the covered pot is several months, while that of the open pot is about six weeks; the length of time, howcrer, in each case, may be more or less. It is possible to melt a much better quality of glass in the covered pot than in the open pot, as the hooded top excludes many inmpurities caused by combustion. The number of covered pots in a furnace is from 8 to 16 . In firing the open-pot furnace the aim is to derelop in the combustion space between the pots and above them a solid flame, but with the corered pots, the flame must be divided so as to play close around each pot. To this end the flame is drawn from the center of the furnace to a series of flues at the breast wall, a flue being placed between each pot and the adjoining pot. The crown of the furnace comes just above the pots and the stack widens at the base sufficiently to take in the entire diameter of the furnace. The draft flues empty into the stack through the breast wall or through the crown. These furnaces are adapted for recuperatire gas firing or direct coal firing. In the oval covered pot furnace the stack is at one side, as with the regenerative tank: greater economy of space in setting the pots is secured as well as better heating results. One nethod of treatment of the waste heat in a furnace of this kind is to convey it by a series of flues so as to heat the water system that heats the entire factory plant.

The first successful gas-fired glass-melting pot furnace was developed abroad in 1861. the solid fuel being eonverted into gas in a producer outside of the furnaee. Several years were required to introduce this improrement into glass manufacture in this country. This application of gas is one of the chief improrements in modern glass making: making possible a saring in the cost of fuel of fully 50 per cent orer the cost with the direct-fired furnace, greatly reducing the time of melt. improving the quality of the glass, and lengthening the life of the pot. However, the disadrantages attending the pot system of melting created a demand for a srstem to melt and blow the glass continuously; these disadvantages were the time lost with the pot srstem (fully one-half the time being spent in cooling and settling the metal, working out the glass, and reheating the furnace). and the constant loss incurred by breaking pots. one broken pot so disturbing the rest of the furnace that the full capacity is frequently unarailable for a considerable time. This led to the developnent of the tank furnace, whieh was used in Europe in 1861 and improred 
in 1872. However, the general introduction of the tank into glass manufacture in the Lnited States dicl not occur until 1s8s, the successful operation of the continuous tank for window glass at Jeannette. Pa.. in that year probably marking its actual introduction into the glass industry of this country. The chief adrantages of the tank over the pot furnare are increased production. econony in operation. durability of furnace. regularity of working, and intensity of heat.

The day or intermittent tank is practically a pot furnace with one large open pot comprising the entire hearth, which is a square or oblong box built up of fire clay blocks and well rentilated on the bottom to prevent excessive wear and leakage occurring when the glass gets too hot or soft on the bottom. The air and gas are brought up through flues at one end and the produets of combustion are discharged through flues at the other end. Either the regenerative or recuperative system can be used. There were 130 dar tanks reported in operation during the eensus sear. 117 of which were in establishments manufacturing bottles and jars and flint ware of all rarieties, the arerage capacity of the tank in such establishments being 6 tous, equal to 6 pots; and 13 in establishments manufacturing sky light glass, glass tiling, rolled glass, and window glass. The greatest obstacle to the successful use of the dar tank on flint glass has been the maintenance of eolor caused br the glass melting principally from the top, leaving the glass at the bottom of the tank less fluid and more refractory. but during the past decade this tank has been so improred that, at present, a very fair grade of so-called flint glass is in manr cases being produced, at a great saring in cost orer the pot-melting method. With these small tanks the use of gas for fuel probably produces the best results, but oil is being introduced for this purpose with a marked degree of success. ${ }^{1}$

The glass melting capacity of continuous tanks reported active in 1900 was $12 . \pm$ per cent of the total for the United States: pot furnaces with a total capacity of $t, 300$ pots were reported, day tanks of a capacity equivalent to 818 pots. and continuous tanks of a eapacity equiralent to 3,775 pots, $2, \pm 76$ of which were operated on bottles and jars and pressed and blown ware, and 1.299 on building grass. The continuous tank is confined largel to the manufacture of bottles and jars and window glass, 2 shifts being worked in the bottle trade and 3 in the window. The continuous regenerative melting tank contains an immense quantity of molten glass and is always full or nearly so. The window tank is oblong, four or fire times as long as the width, with a capacity rarying from 6 to 20 rings, each ring being equiralent to a eapacity of 3 pots. The bottle tank is much shorter and wider than the window tank, and has an arerage of about 10 rings,

\footnotetext{
${ }^{1}$ Elements of Glass and Glass Making, Biser, 1900, page 62.
}

each ring being equiralent to a capacity of 2 pots. The average window tank has 8 rings. or a capacity of 24 blowers or pots. Inside it is 14 feet wide. io feet long, and 5 feet deep, and will contain about 42.5 tons of molten metal. The batch is filled in continuously at one end and drawn, melting as it goes. to the working holes at the other end, where it is worked out. Near the working end of the tank is a thoting bridge of prepared clay, extending down about one-fourth of the depth of the tank, which hreaks the surface of the mass of glass and acts as a purifier. the completely melted glass passing beneath the floater into the rorking end of the tank. while the impure glass, which rises to the top, is held in check until properly melted. The wall of the working end of the tank is pierced by working holes through which the glass is gathered, in front of each hole being a deep clay ring stationed in the glass, the refined metal coming into this ring through the bottom and being gathered from the ring by the workman. The bottom and sides of the tank are well rentilated, to lessen the strain on the structure. The regenerator's are at either side of the tank foundations. and the flues lead to ports in the side walls or to ports that open through the crown, the flame entering the furnace above the surface of the glass and just beneath the crown. All arrangements are made with a view to developing a nearly continuous sheet of flame.

A modification of the eontinuous tank for window glass, styled the blow-orer tank, was introduced into this countr 5 in 1900, though in use abroad for a number of years. There were three or four sueh plants erected. $\mathrm{By}$ the use of the blow-orer tank the blow furnace for "warming in" the roller of glass during the blowing operation is dispensed with, as the roller" is " warmed in" directly orer the mass of molten glass in the tank, the heat of the tank accomplishing this purpose, which effects a saring in fuel of about 50 per cent, for as mueh fuel is often required for the blow furnaces as for the melting tank. This improvement is made by lengthening the working end of the tank to permit a series of warming-in holes on each side between the floater's and the gathering holes. The results so far obtained with the blow-orer tank will probably lead to its general introduction, as. in addition to the great saring in fuel cost, the heat is much more constant and uniform than with the blow furnace.

The use of oil as a fuel for glass melting has greatly increased during the last ten years. One of the most successful methods of oil firing is the use of the cheap, heary oil of 34 to 40 specific gravit 5 , practically a refiner $y$ by-product. with an air pressure of from 2 to 7 ounees per square inch. The air meets the flow of oil at the end of the burner and completely atomizes it in a sprar, furnishing just enough oxygen to perfeet eombustion. Oil is adrantageous as a clean fuel of high calorific ralue and perfect safet $y$, but the eost restricts its general use. Benzine is largely used in certain 
branches of the glass industry as fuel, being especially well adapted for fuel for glory holes, particularly in the manufacture of bottles, producing an intense uniform heat and requiring but little attention.

\section{DETAILED STATISTICS OF GLASS MANUFACTURE.}

The detailed statisties for the industry as reported are shown in Tables 12, 13, and 1t; Table 12 presenting statistics of the entire industry: Table 13 , of the manufacture of building glass: and Table $1 t$, of the manufacture of pressed and blown glass, and bottles and jars. These tables present separate totals for each state in which there were 3 or more establishments, and group the statistics for other states, so as not to disclose the operations of indiridual establishments. The establishments are classified according to the charaeter of the ownership, which shows that in the building glass branch of the industry, 6 were owned by individuals. 11 by part- nerships, 102 by corporations. and 5 wre of a miscellaneous character; and in the manufacture of presed and blown glass, and bottles and jars, 2:, were rwned by individuals, 49 by partnerships, $15 t$ by corporations. and were of a miccellaneous character. The employees are classitied so as to show for salarierl officials. clerks, ete., and for wage-earners separately the number and salaries or wages of men, women, and children. respectively, and also the arerage number of wageearners employed during each month of the rear. Separate totals are shown for the different material. presenting the quantity and cost of each; and the quantity and value of the several products manufactured. and the value of all other products, are given. The number of engines, water wheel.s, electric motors, and other forms of power in use, with their horsepower" are shown. The cstablishments are grouped in the tables according to the number of emplorees in each.

TABle 12.-GLASS MANUFACTURE, BY STATES: 1900.

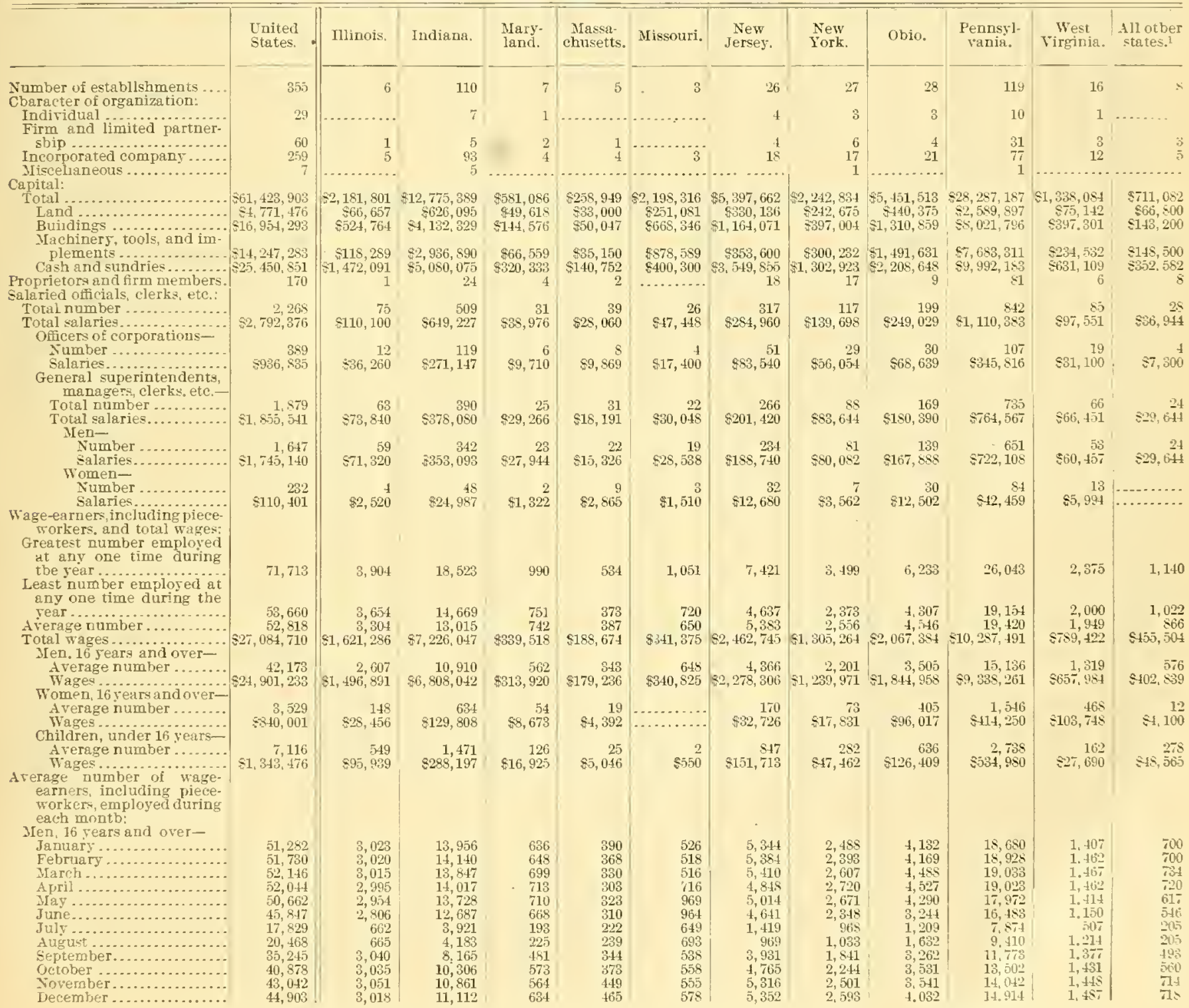


TABLE 12.-GLASS MANUFACTURE, BY STATES: 1900-('ontinued.

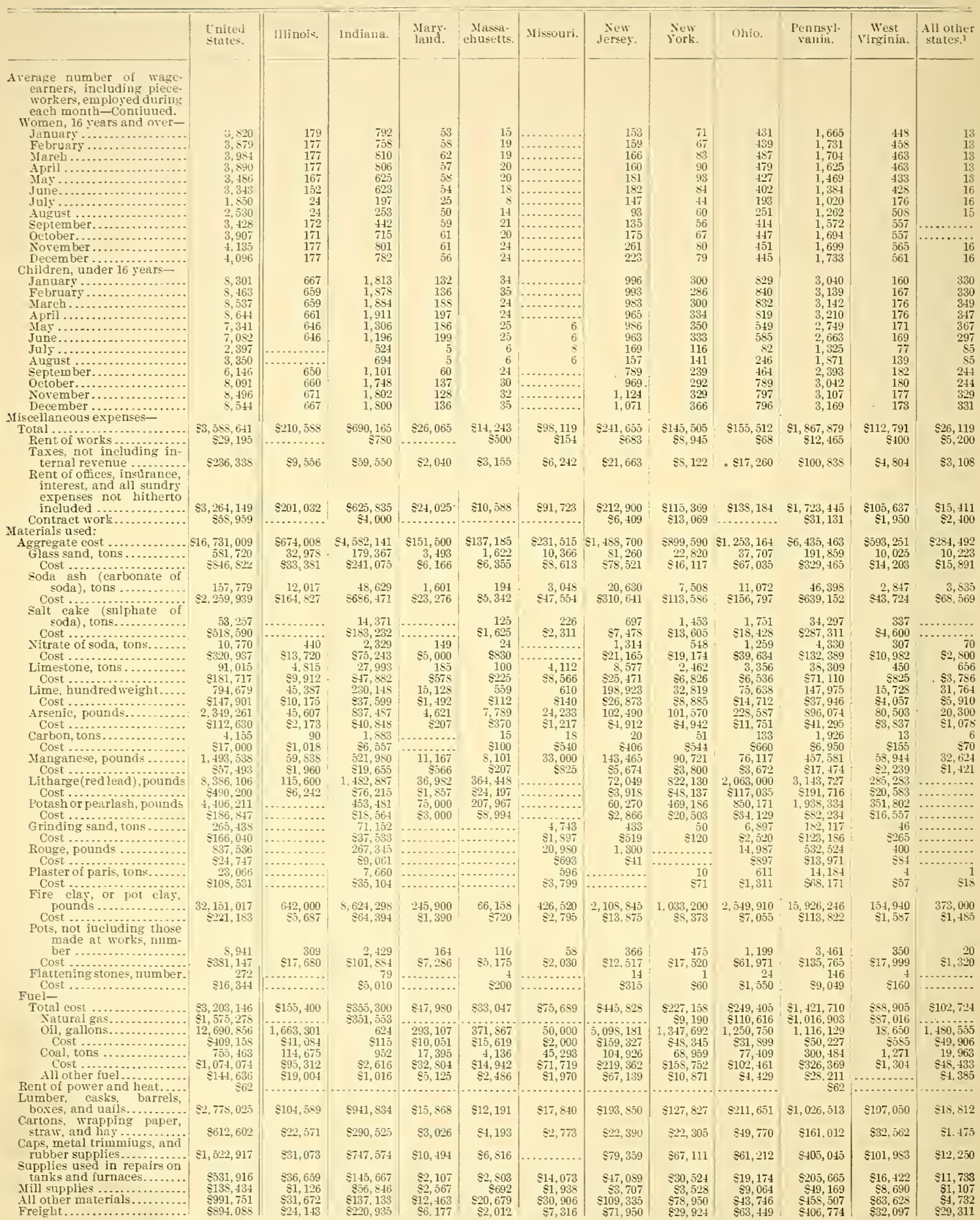
1 Includes estabishments distributed as follow: California, 1; Colorado, 1; Delaware, 1: Georgia, 1: Michigan, 1; Yirginia, 2: Wisconsin, 1. 
TABLE 12.-GLASS MANUFACTURE, BY STATES: 1900-Continuer.

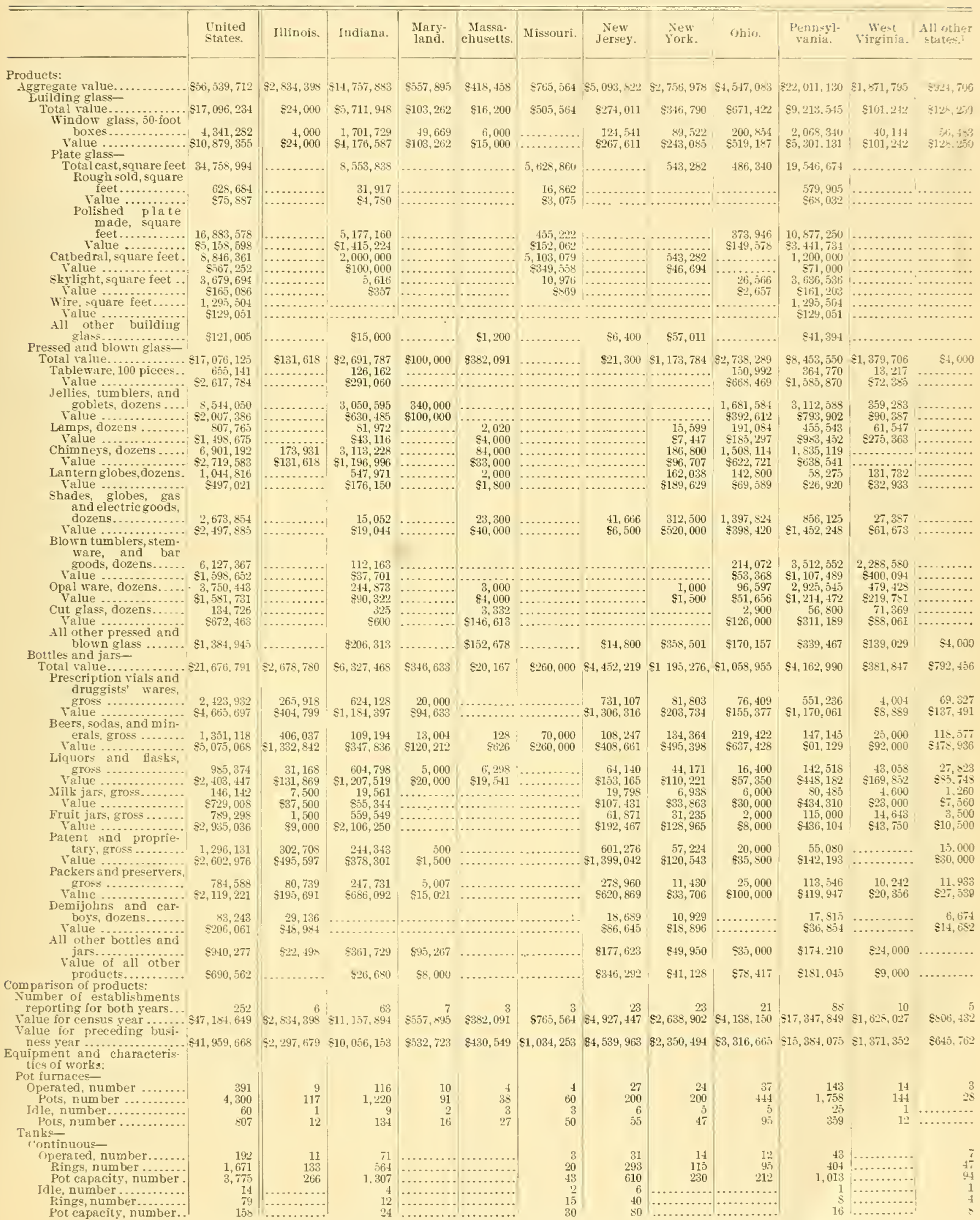

1 Includes establishments distributed as follows: California, 1; Colorado, 1: Delawarc, 1; Georgia, 1; Michigan, 1; Virkrinia, 
TABLE 12.-GLASS MANUFACTLRE, BY STATES: 1900-Continued.

\begin{tabular}{|c|c|c|c|c|c|c|c|c|c|c|c|c|}
\hline & $\begin{array}{l}\text { Enited } \\
\text { States. }\end{array}$ & Illinois. & Indiana. & $\begin{array}{l}\text { Mary. } \\
\text { land. }\end{array}$ & $\begin{array}{l}\text { Massa- } \\
\text { chusetts. }\end{array}$ & Missouri. & $\begin{array}{l}\text { New } \\
\text { Jersey. }\end{array}$ & $\begin{array}{l}\text { Nown } \\
\text { lork. }\end{array}$ & Ohio. & $\begin{array}{l}\text { Penusyl- } \\
\text { vania. }\end{array}$ & $\begin{array}{l}\text { West } \\
\text { virginiu. }\end{array}$ & $\begin{array}{l}\text { 111 other } \\
\text { stutes.1 }\end{array}$ \\
\hline \multicolumn{13}{|l|}{$\begin{array}{l}\text { Equipment and cliaracteris- } \\
\text { ties of work - Continued. } \\
\text { Intermittent or day- }\end{array}$} \\
\hline Ojerated, number ......... & 130 & 7 & 33 & 1 & 1 & & 12 & $\bar{i}$ & 3 & 44 & 19 & 3 \\
\hline $\begin{array}{l}\text { Tonscapacity, number } \\
\text { Poreapacity number. }\end{array}$ & 818 & 40 & 208 & i & 901. & & 72 & 49 & 13 & 232 & 85 & 23 \\
\hline $\begin{array}{l}\text { Pocenpacity, number.. } \\
\text { Idle, number ........... }\end{array}$ & 818 & -40 & 208 & 6 & 90 & & 72 & 49 & 13 & 232 & 85 & 23 \\
\hline $\begin{array}{l}\text { Idle, number ........... } \\
\text { Tonscapacity, number }\end{array}$ & 83 & & 12 & a...... & & $\cdots \cdots \cdot$ & $\frac{2}{7}$ & 1 & 3 & $\begin{array}{r}5 \\
10\end{array}$ & 1 & 1 \\
\hline Pot.cupacity, number.. & 83 & & 12 & ..... & ........ & & 7 & $\begin{array}{l}3 \\
3\end{array}$ & 12 & $\begin{array}{l}42 \\
42\end{array}$ & 5 & $\frac{2}{2}$ \\
\hline \multicolumn{13}{|l|}{$\begin{array}{l}\text { building glass- } \\
\text { Flattening orens, number. }\end{array}$} \\
\hline $\begin{array}{l}\text { Monkey ovens, number ... } \\
\text { Blow furnaces, number... }\end{array}$ & $25 \frac{2}{9}$ & & 135 & & 1 & & & 10 & & & 4 & \\
\hline Casting tables. number..... & 100 & $\ddot{4}$ & 17 & (n.... & ... & 14 & $\cdots$ & 5 & $\begin{array}{r}10 \\
3\end{array}$ & 57 & ‥ & \\
\hline & 869 & & 258 & (...... & & 98 & & 5 & 23 & 485 & ..... & -.. \\
\hline $\begin{array}{l}\text { Bending ovens, number ... } \\
\text { Lehrs, number............ }\end{array}$ & 302 & $\cdots$ & 115 & 2 & 1 & 2 & 5 & 12 & 13 & $14 \frac{4}{7}$ & 3 & $m_{2}$ \\
\hline 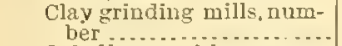 & 63 & & 22 & 2 & 1 & 1 & & & & & & \\
\hline & $\infty$ & & $-\pi$ & & & 1 & 3 & 6 & 3 & 23 & 1 & 1 \\
\hline Polishing machines, num- & 227 & & 61 & 1 & & 21 & & 3 & 12 & 129 & & \\
\hline sand-blastmachines, num- & 294 & & 86 & & & 24 & & & 10 & 174 & & \\
\hline $\begin{array}{l}\text { ber .......... } \\
\text { Glassware bottles- }\end{array}$ & 5 & & 1 & & & & & 1 & & 3 & & \\
\hline & 3,978 & 427 & 1,397 & 67 & 38 & 26 & \multicolumn{6}{|c|}{ Glassware and bottles- } \\
\hline Glory holes, number....... & 1,419 & 146 & 351 & 24 & 16 & 6 & - 301 & 66 & 93 & 351 & $\begin{array}{r}158 \\
28\end{array}$ & $\begin{array}{l}78 \\
37\end{array}$ \\
\hline $\begin{array}{l}\text { Annealing ovens, number. } \\
\text { Lehrs number }\end{array}$ & 1.540 & 289 & 161 & 21 & 15 & 32 & 266 & 126 & 121 & 395 & 18 & 96 \\
\hline $\begin{array}{l}\text { Lehrs, number } \\
\text { Decorating kilns, number }\end{array}$ & 1,025 & 31 & 321 & 18 & 12 & & 95 & 55 & 102 & 323 & 59 & 9 \\
\hline $\begin{array}{l}\text { Decorating kilns, number } \\
\text { Decorating lelurs, number. }\end{array}$ & $\begin{array}{r}105 \\
23\end{array}$ & $\cdots \cdots$ & $\begin{array}{l}6 \\
1\end{array}$ & 1 & 8 & 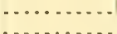 & $\cdots \cdots \cdots \cdots$ & 1 & 27 & 55 & 7 & - \\
\hline $\begin{array}{l}\text { Decorating lents, number. } \\
\text { Presses, band, number... }\end{array}$ & 915 & 13 & 197 & 7 & 9 & & $\cdots$ & 49 & 125 & $\begin{array}{r}15 \\
402\end{array}$ & 57 & $\cdots_{i}$ \\
\hline 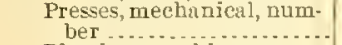 & 49 & & 4 & & & & & & & & & \\
\hline $\begin{array}{l}\text { Blowing maebines, num- } \\
\text { ber ...................... }\end{array}$ & & & & & & & & & & 42 & 3 & \\
\hline & 169 & 1 & 80 & & & & 4 & 1 & 18 & 65 & & \\
\hline $\begin{array}{c}\text { ber } \\
\text { Crimping machines, num- }\end{array}$ & 140 & 2 & 33 & & & & 1 & 2 & 59 & 42 & 1 & \\
\hline $\begin{array}{l}\text { ber } \\
\text { jlechanical polisbers num- }\end{array}$ & 494 & 1 & 169 & 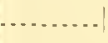 & 5 & & & 32 & 35 & $=252^{\circ}$ & & \\
\hline 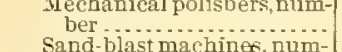 & 16 & & & & 1. & & 1 & 1 & 1 & 12 & & \\
\hline $\begin{array}{l}\text { Sand-blast machines, num- } \\
\text { ber -.................. }\end{array}$ & 68 & 1 & 8 & & 3 & & 1 & 9 & 10 & 27 & & \\
\hline $\begin{array}{l}\text { Grinding machines for } \\
\text { fruit-jar tops, number }\end{array}$ & 137 & 3 & 29 & 4 & . & & & 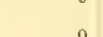 & 10 & 21 & 9 & \\
\hline Claj-grinding mills, number & 8 & $\cdots$ & 1 & 7 & & & $\begin{array}{r}22 \\
1\end{array}$ & 9 & $\begin{array}{l}5 \\
2\end{array}$ & $\begin{array}{r}54 \\
4\end{array}$ & 10 & 1 \\
\hline $\begin{array}{l}\text { Mechanical stokers, number. } \\
\text { Horses and mules, number . }\end{array}$ & 79 & & & & & & 3 & 14 & 8 & 52 & $\ldots$ & 2 \\
\hline $\begin{array}{l}\text { Horses and mules, number - } \\
\text { Wagons, carts, and drays, }\end{array}$ & 409 & 23 & 21 & 13 & 8 & 9 & 98 & 49 & 18 & 134 & 6 & 30 \\
\hline $\begin{array}{l}\text { number ....................... } \\
\text { Power: }\end{array}$ & 407 & 24 & 23 & 17 & 9 & 7 & 111 & 47 & 18 & 126 & 6 & 19 \\
\hline \multicolumn{13}{|l|}{$\begin{array}{l}\text { Power: } \\
\text { Number of establishments }\end{array}$} \\
\hline 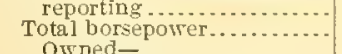 & $\begin{array}{r}330 \\
58,929\end{array}$ & $\begin{array}{r}6 \\
700\end{array}$ & $\begin{array}{r}99 \\
11,386\end{array}$ & $\begin{array}{r}7 \\
240\end{array}$ & $\begin{aligned} 4 \\
199\end{aligned}$ & 3,592 & -25 & 25 & 27 & & 14 & 8 \\
\hline $\begin{array}{c}\text { steam, number....... } \\
\text { Horsepower }\end{array}$ & 753 & It & 187 & \multicolumn{9}{|c|}{$\begin{array}{l}\text { Owned- } \\
\text { Engines- }\end{array}$} \\
\hline $\begin{array}{l}\text { Horsepower ........... } \\
\text { Gas, or gasoline, num- }\end{array}$ & 49,791 & 700 & 10,333 & 230 & 100 & 3,110 & $1,6 \mathrm{~S} 1$ & 1,017 & 3,426 & 27,732 & $\begin{array}{r}17 \\
773\end{array}$ & $\begin{array}{r}12 \\
689\end{array}$ \\
\hline $\begin{array}{c}\text { Gas, or gasoline, num- } \\
\text { ber ....................... }\end{array}$ & $\$ 1$ & & 23 & & 1 & & & & & & & \\
\hline Horsepower ............. & 2,364 & .... & 585 & & $\frac{1}{7}$ & & $\frac{1}{5}$ & 1 & 13 & & 4 & \\
\hline Water wheels, number.. & & & & & 1 & & & 30 & 235 & 1,322 & 160 & \\
\hline $\begin{array}{l}\text { Horsepower .......... } \\
\text { Electric motors, number }\end{array}$ & 27 & & & & 12 & & & & $\cdots$ & $1 \frac{1}{5}$ & & \\
\hline Electric motors, number & 178 & & 18 & 1 & 1 & 15 & & & 45 & 97 & 1 & \\
\hline Horsepower ........... & 5,986 & & 468 & 10 & 40 & 482 & & & 3,605 & 1,361 & 20 & ...... \\
\hline Other power, number... & $\begin{array}{r}25 \\
-705\end{array}$ & & & & & & -4 & 4 & 6 & 10 & 1 & ............ \\
\hline \multicolumn{13}{|l|}{$\begin{array}{l}\text { Horsepower ............. } \\
\text { Rented- }\end{array}$} \\
\hline $\begin{array}{l}\text { Electric, horsepower } \\
\text { Other kiud, horseposer }\end{array}$ & 44 & & & & 40 & & & & & 1 & & 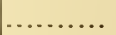 \\
\hline \multicolumn{13}{|l|}{$\begin{array}{l}\text { Other kind, horseposer } \\
\text { Furnished to other establish- }\end{array}$} \\
\hline $\begin{array}{l}\text { ments, horsepower } \\
\text { Establishments classified by }\end{array}$ & 10 & & & & & & & 10 & & & & \\
\hline \multirow{3}{*}{\multicolumn{13}{|c|}{$\begin{array}{l}\text { Establishments classified by } \\
\text { numberof personsemployed. } \\
\text { not including proprietors } \\
\text { and firm members: } \\
\text { Tota number of establish- }\end{array}$}} \\
\hline & & & & & & & & & & & & \\
\hline & & & & & & & & & & & & \\
\hline ments & $\begin{array}{r}355 \\
1\end{array}$ & 6 & 110 & 7 & 5 & 3 & 26 & 27 & 28 & 119 & 16 & 8 \\
\hline 5 to $20 \ldots$ & 5 & 1 & 2 & & & & & & 1 & 1 & & (n) \\
\hline 21 to $50 \ldots$ & 33 & & 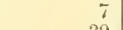 & & 1 & & 3 & 9 & 2 & $S$ & 3 & (n........ \\
\hline $\begin{array}{l}51 \text { to } 10001 \text { to } 250 \ldots \\
100 .\end{array}$ & $\begin{array}{r}93 \\
139\end{array}$ & & $\begin{array}{r}39 \\
43\end{array}$ & $\begin{array}{l}3 \\
3\end{array}$ & $\frac{2}{2}$ & n........... & $\begin{array}{r}5 \\
11\end{array}$ & $\begin{array}{l}7 \\
7\end{array}$ & $\begin{array}{r}3 \\
12\end{array}$ & $\frac{24}{55}$ & $\begin{array}{l}5 \\
3\end{array}$ & 5 \\
\hline $\begin{array}{l}101 \\
251 \text { to } 2500 \ldots \ldots \ldots \ldots \ldots \ldots \ldots \ldots \\
\end{array}$ & 58 & 2 & 14 & 1 & & $\frac{1}{2}$ & $\begin{array}{r}11 \\
3\end{array}$ & 4 & 8 & 18 & 4 & $\frac{1}{2}$ \\
\hline $\begin{array}{l}501 \text { to } 1,000 \ldots \ldots \ldots \ldots \\
\text { Orer } 1,000 \ldots \ldots\end{array}$ & $\frac{21}{5}$ & 2 & $\begin{array}{l}4 \\
1\end{array}$ & & & & $\begin{array}{l}3 \\
1\end{array}$ & & 2 & $\begin{array}{r}12 \\
1\end{array}$ & & \\
\hline
\end{tabular}

Ineludes establishments distributed as follows: California, 1; Colorado, 1; Delaware, 1; Georgia, 1; Michigan, 1; Virginia, 2; Wisconsin, 1. 
TABLe 13.-BUILDING GLASS, BY STATES: 1900.

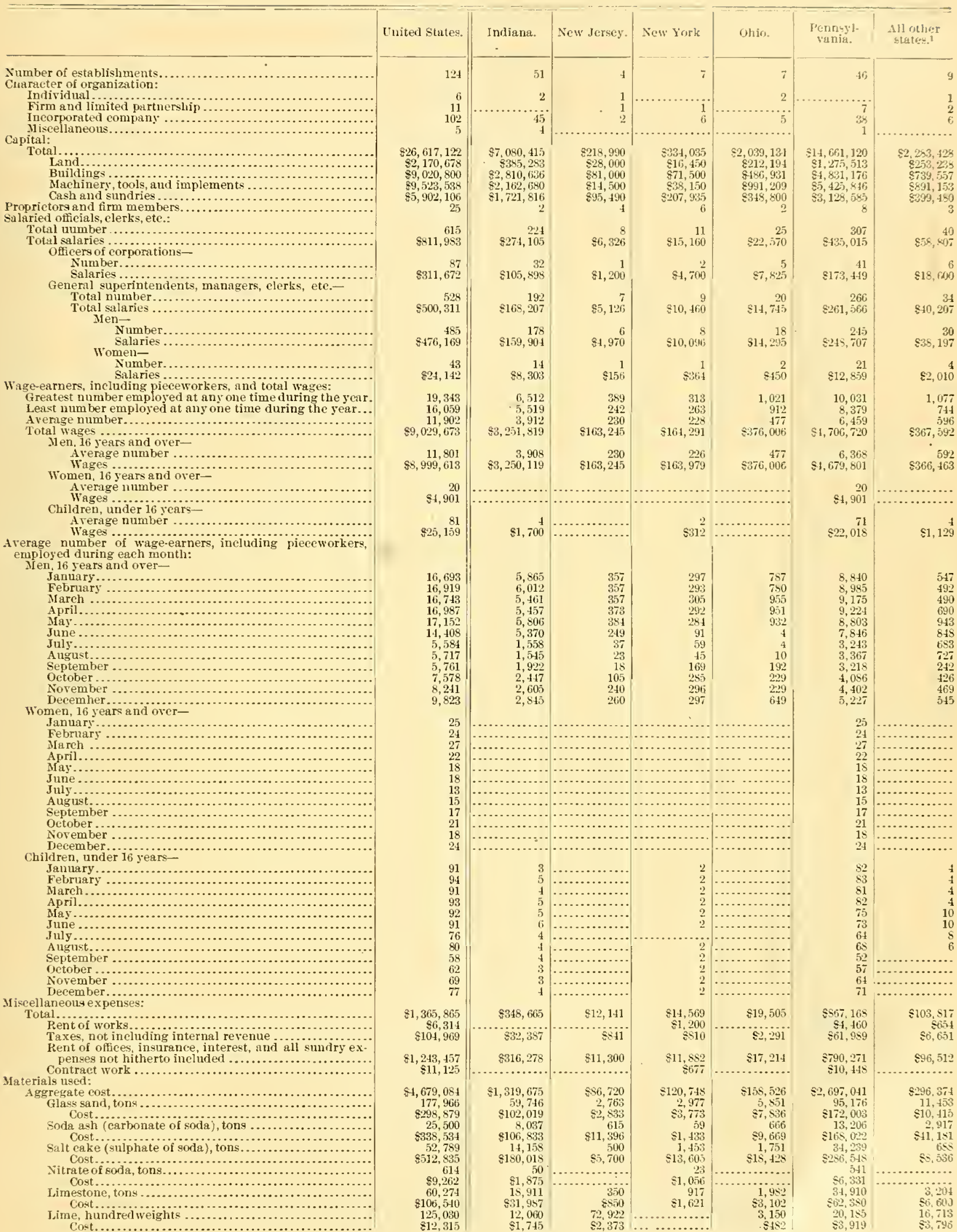

1 Inrludes establishmenta distributed as follows: Mllinois, 1; Maryland, 2; Massachnsetts, 1; Miscouri, 2; West Virginia, 2; 19elaware, 1. 
T. BLE 13.-BUIJDING GL.LSS, liY STATFA: 1900-Continued.

Naterials used-Continued. Arstinic, pound.

arbon, tons

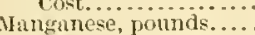

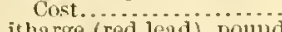

itharge

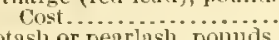

Grinding sand, tons

Cost.

Rouge, pounds..............

Cost.

Pots (not including those niade at works), number.

Cost...

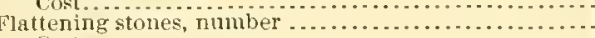

Fuel-

Total cost

Tatural gas

Oil, gallon

Coal, tons.

$$
\text { All other fuel }
$$

Lumber, casks, barrels, boxes, and nails

Cartons, irrapping paper, striw, and hay

Supplies used in repairs on tanks and firnaces............

Alt other moteric

Products:?

Total value

Bnilding glass-

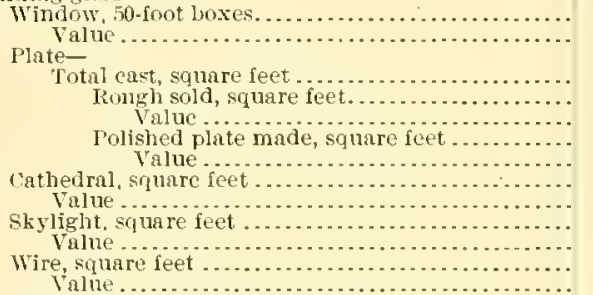

Value $\ldots$.................

comparison of products:

Number of establisliments reporting for both years.

Value for censtis year

Value for preceding business year-

Equipment and characteristics of work:

ot inrmaces-

Operated, number

Pots, number

$$
\text { Cont }
$$

Continuous-

Operated, number Rings, number......

Intermittent, or day-

operited, number

Tons cupacity, number

Pot capicity mumer.

Idle, number

Tons rapacity, nimber

Flattening ovens, number

lionkey ovens, number.

Blow furnaces, number.

Annealing ovens, number

Bending ovens, number

Lebrs, number.

Cley-grinding inilis, number

Grinding machines, number.

Polishing machines, number

Sand-blast machines, number

Neehanical stokers, number

Horses and mules, number ........
Wagons, carts, and drays, number

Power:

Number of establishments reporting .

Total horsepo

owined-

$$
\begin{aligned}
& \text { gines- } \\
& \text { Steam, number ........ } \\
& \text { Horwepower........ } \\
& \text { Gas or gasoline, number } \\
& \text { Horsepower. }
\end{aligned}
$$
f graruate cont-Continued.

Potash or pearlash, pounds.

Plaster of parie, tons.

Fire clay or pot elay, pound

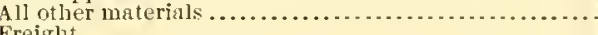

l'ots, numbe

Casting tables, number.

\section{Ini}

wited States.

$1,321,130$

जी 3,067

\&1.t, 199

65, 600

$35,5: 1$

82,27

S3, 704

263,933

835,749

524,148
22,980

22,980
$\$ 107,434$

$3,510,700$

5170,522

s101, 061

$\$ 16,344$

\&1, 119,022

$\$ 751,354$

723,654
$\$ 23,161$

$\$ 23,161$
269,611

335,856

55,651
$5,27,663$

$\$ 43,597$

247,538

$\$ 65,616$

$\$ 296,155$
$\$ 234,855$

$\$ 17,096,234$

4, 341, 282

\$10,879, 350

$34,758,994$

$628,68-1$

$16,853,578$

35. 158,598

$8,846,361$

$3,679,694$

8165,086
$1,295,504$

ह129,051

$\$ 121,005$

59
$\$ 9,574,171$
$\$ 9,668,452$

Incluna.

Temer

164
1,825
29

29
471

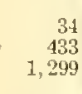

34
433
1,299

13
124
12
1
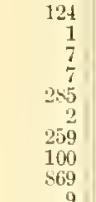

9
302
63
227
29

59
5
62
92
93

111
43,939

442
37,161
25

161
25
685

10,000
$\$ 510$

70,853
836,811

$\$ 36,811$

\$9, 061

7,626
834,610

7. 282,228

$\$ 57,310$
1,482
815,035

845, 035

55,010

8195,376

5193,590

489
578
432

$\begin{array}{r}432 \\ 81,128 \\ \hdashline 570\end{array}$

$\$ 25 \div, 905$

$\$ 13,252$
872,010

872,010
837.290

856.922
ज्ञ1, 299

$85,711,948$

1,701,729

$8,553,838$

31,717
8400

$5,177,160$
$\$ 1,415,224$

196,840

196,810
$\$ 2,145$

65
$\times 1,300$

14
8315

s 30,343

133,414

ㄴ, 070
12,406

12,406
824,905

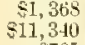

$\$ 11,340$
की
-85

$\$ 2,650$

7240
8,788

$\$ 9,379$

$\$ 274,011$

124, 541

.

$\leqslant 15,000 \quad \cdots \cdots \cdots \cdots$

$83,088,860$

$82,908,757$

$\$ 204,011$
$\$ 215,388$

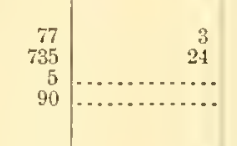$$
\begin{array}{r}
135 \\
17 \\
258 \\
5 \\
115 \\
22 \\
61 \\
86 \\
1
\end{array}
$$

$s_{1}$

$$
\begin{aligned}
& 14 \\
& 13
\end{aligned}
$$

\begin{tabular}{|c|c|c|c|}
\hline mliana. & New Jersey. & Sew York. & Ohio. \\
\hline & & - & \\
\hline $\begin{array}{r}517,839 \\
825,807 \\
1,817 \\
86,135 \\
13,000\end{array}$ & 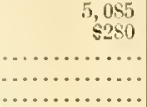 & $\begin{array}{r}40,552 \\
82,066 \\
17 \\
8310 \\
1,200\end{array}$ & $\begin{array}{r}105,243 \\
54.575 \\
133 \\
8660\end{array}$ \\
\hline
\end{tabular}

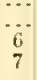

8, 741

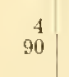

127
8,230

143

\begin{tabular}{c|c}
4 \\
90
\end{tabular}

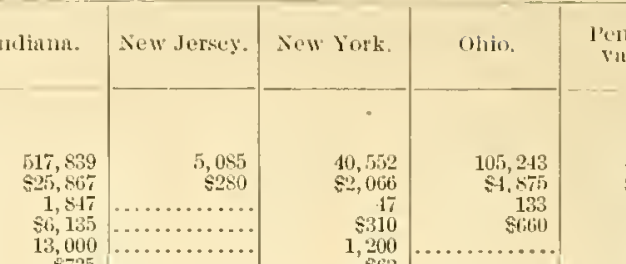

31,221

3. 2,023

54,748
จุ․ 951

557,011

5
$\$ 251,714$
$\$ 177,837$

288,750

52,438

332
$\$ 10,395$

1
860

842,711

54,171

82,742
20,769

$\$ 37,450$

32,549
514,546

$\$ 2,531$

8550
89,417

89,417
$\$ 8,293$

$\$ 340,790$

89,522

6,800

6,800
S2. 040

14,900

5723
600

81,200

, 603,910

54,749

$\$ 9,110$

24
81,550

835,772

$\$ 11,212$

$11:$
$\$ 225$
28,593

28,593
824,323

$\begin{array}{r}\$ 212 \\ \$ 833,227 \\ \hline\end{array}$

$\$ 1,247$

$\$ 7,660$
$\$ 1,460$

81,460
81,995

\$9, 730

671,422

200,854

s9 $9,213,545$

$2,068,340$

$19,546,674$

579,905

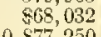

$10,877,250$

...........

$3,636,536$

$\$ 161,203$

$1,295,504$

$\therefore 41,394$

1 …...........

$\begin{array}{rr}200 & 6 \\ 4,790,490 & \$ 761,076\end{array}$

$\begin{array}{rr}\$ 1,949,14 i & \$ 1,048,893\end{array}$

156,296
5371,751

$6,658,452$

16,862
$\$ 3,075$

S29, $16 \mathrm{~S}$

$\$ 301,640$

$8,816,361$
$\$ 567,252$

43,158
53,863

$\$ 178,017$
$\$ 368,431$
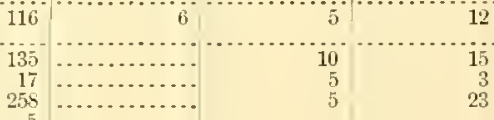

15
3
23

is

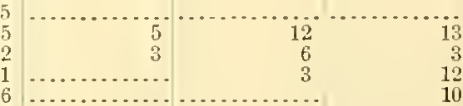

1
2
5
3

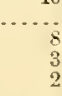

155

6
5,799

155

8
2,250
3
29

$\begin{array}{r}8 \\ 250 \\ 3 \\ 29 \\ \hline\end{array}$

1 Includes establisluments tistributed as follows: Illinois, 1; Maryland, 2; Massachnsetts, 1; Missouri, 2; West Virginia, 2; Delaware, 1. While the aggregate value for the respective states is the aggregate ralue of prodncts reported for building glass manufacture, this total can not
by adding the amounts given, as the report of certain products las been suluressed to aroid disclosing the operations of individual establishments. 
TABLE 13.-BUILDING GLASS, BY STATES: 1900-Continued.

\begin{tabular}{|c|c|c|c|c|c|c|c|}
\hline & United States. & Indjunu. & New Jersey. & New lork. & rhis. & $\begin{array}{c}\text { l'ennsy!. } \\
\text { vanis. }\end{array}$ & $\begin{array}{l}\text { All other } \\
\text { states? }\end{array}$ \\
\hline 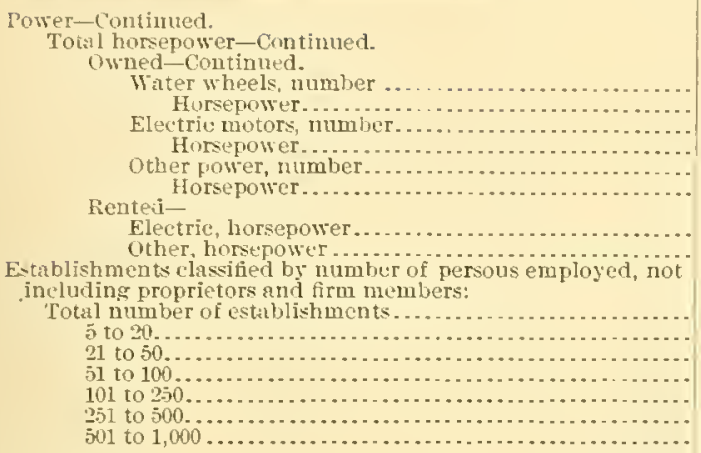 & $\begin{array}{r}1 \\
12 \\
134 \\
5,628 \\
6 \\
410 \\
1 \\
12 \\
\\
124 \\
3 \\
16 \\
43 \\
41 \\
13 \\
5\end{array}$ & $\begin{array}{r}51 \\
2 \\
4 \\
24 \\
15 \\
4 \\
2\end{array}$ & 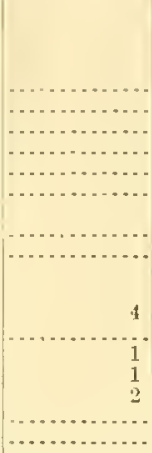 & 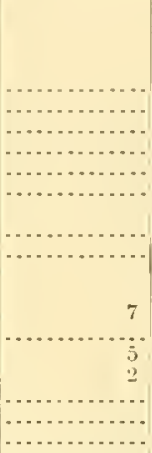 & 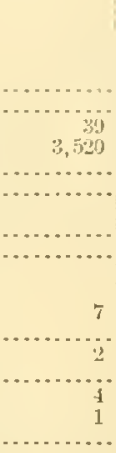 & $\begin{array}{r}975 \\
1,258 \\
6 \\
410 \\
1 \\
12 \\
15 \\
0 \\
12 \\
19 \\
7 \\
6\end{array}$ & 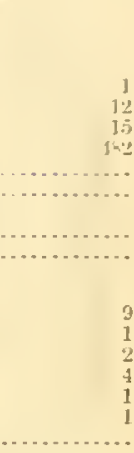 \\
\hline
\end{tabular}

${ }_{1}^{1}$ Ineludes establishments distributed as follows: Illinois, 1; Maryland, 2; Massachusetts, 1; Missouri, 2; West Virginia, 2: Delaware, 1.

TABLE 14.--PRESSED AND BLOWN GLASS AND BOTTLES AND JARS, BY STATES: 1900.

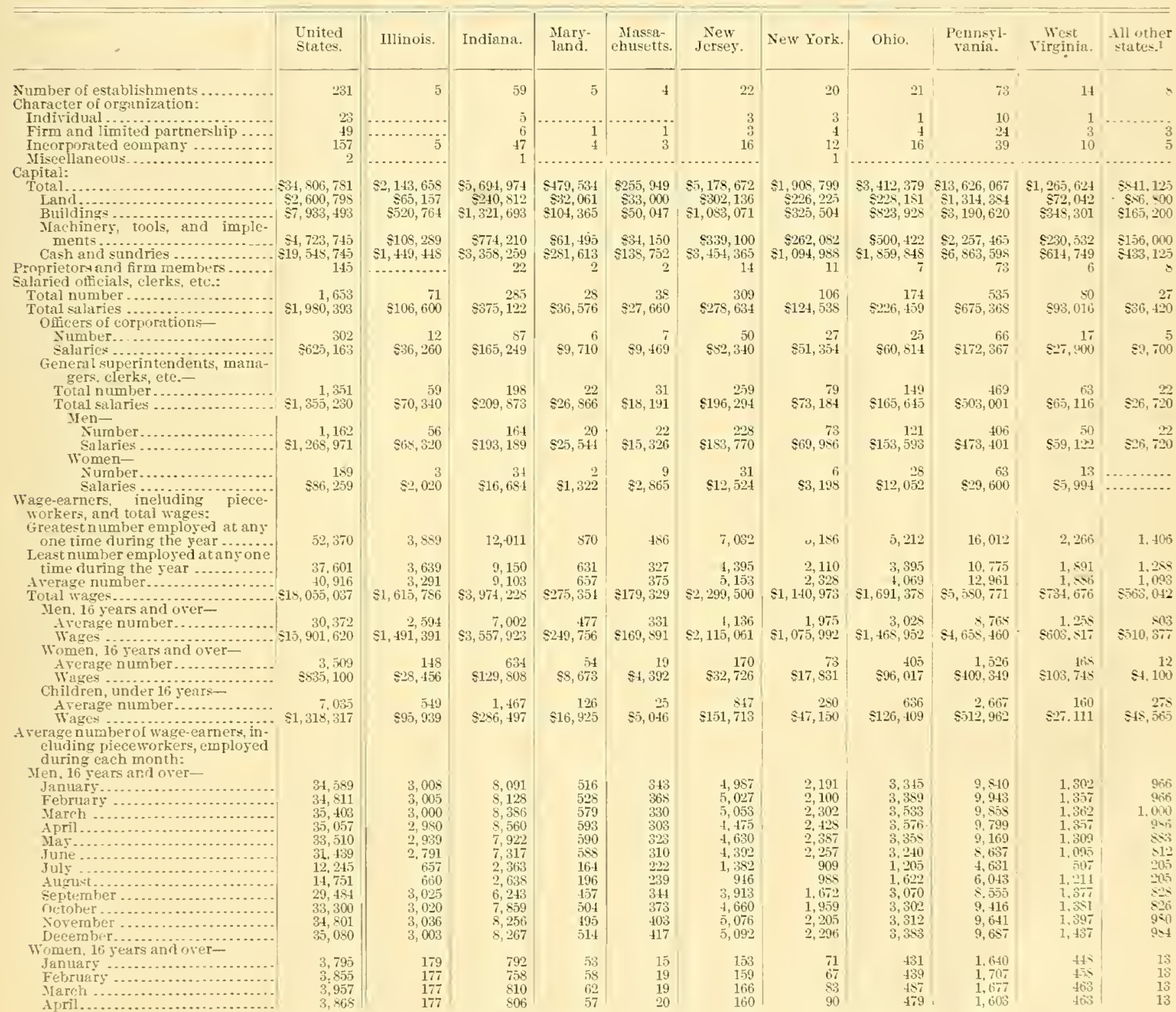

1 Ineludes establishments distributed as follows: California, 1; Colorado, 1; Georgin, 1; 3ichigan, 1; Missouri, 1; Virginia, 2; Wisconsin. 1. 
T.BI.F 14.-PRESSEN AXN BLOWX GLASS AND BOTTLES AND JARS, BY STATES: 1900-Continued.

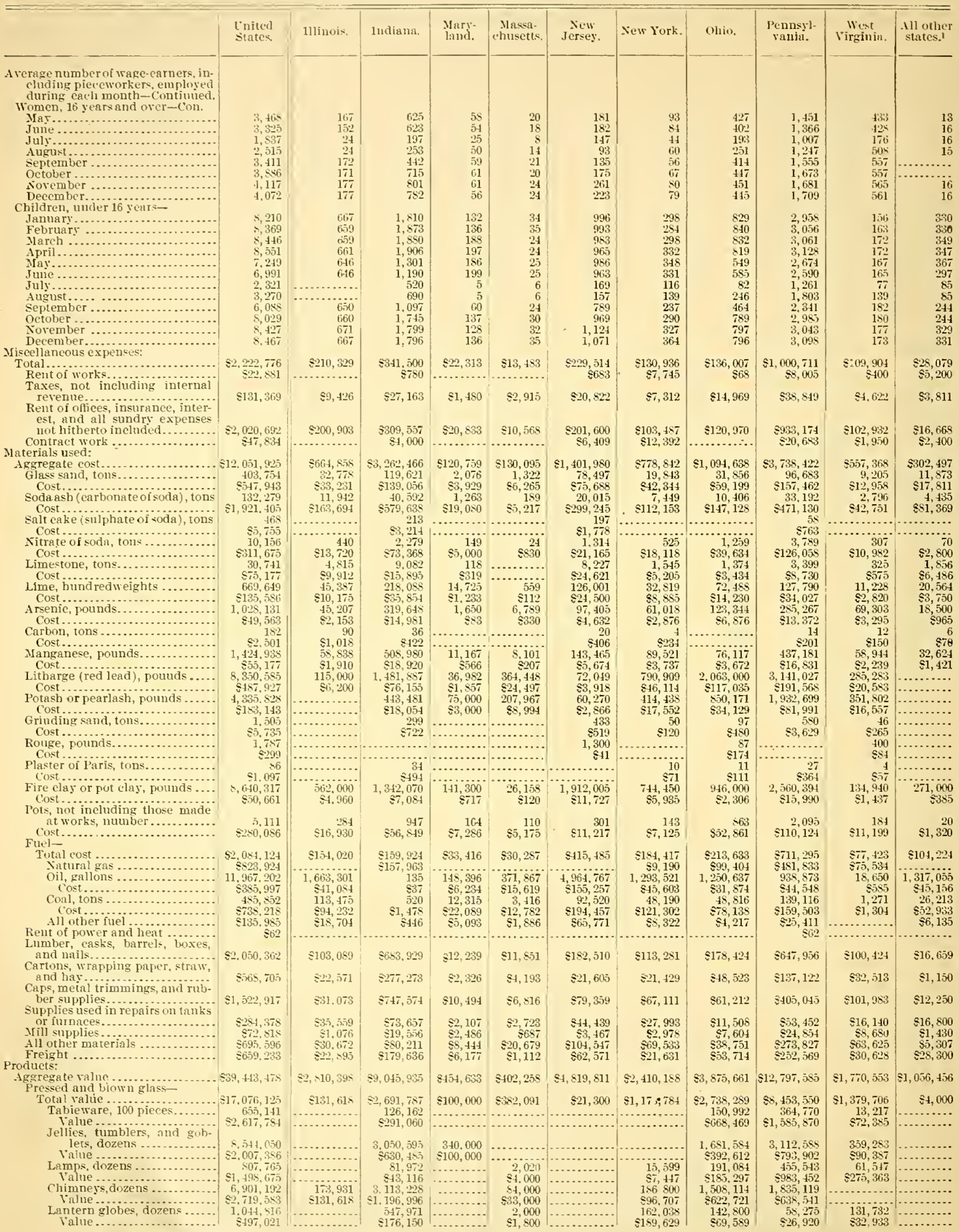

${ }_{1}$ Ineludes establishments distributer as follows: California, 1: Colorado. 1: Georgia. 1: Miehigan, 1; Missouri, 1; Virgiuia, 2; Wisconsin, 1. 
TABLE 14.-PRESED AND BLOWN GLASS AND POTTLES AND JARS, BY STATES: 1900—Continued.

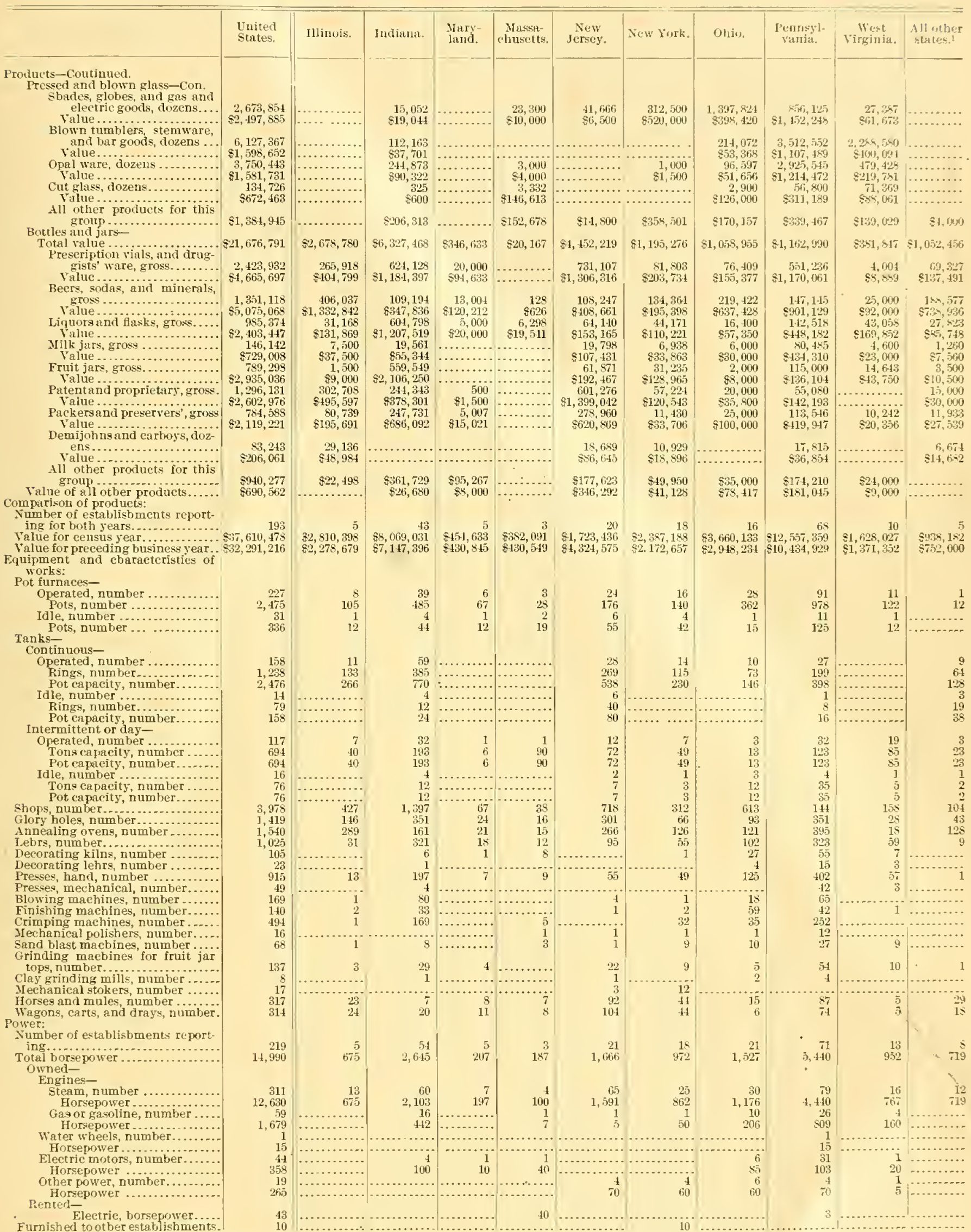

1 Includes establishments distributed as follows; California, 1; Colorado, 1; Georgia, 1; Michigan, 1; xlissouri, 1; Virginia, 2; Wisconsin, 1. 
TABLE 14.-PRESSED AND BLOWN GLASS AND BOTTLES AND JARS, BY STATES: 1900-Continued.

\begin{tabular}{|c|c|c|c|c|c|c|c|c|c|c|c|}
\hline & $\begin{array}{l}\text { Injted } \\
\text { Stutes. }\end{array}$ & Itlinois. & Indiaun. & $\begin{array}{l}\text { Mary- } \\
\text { land. }\end{array}$ & $\begin{array}{l}\text { Musisa- } \\
\text { chusetts. }\end{array}$ & $\begin{array}{l}\text { New } \\
\text { Jersey. }\end{array}$ & New York. & Ohio. & $\begin{array}{l}\text { P'enusyl- } \\
\text { униiи. }\end{array}$ & $\begin{array}{l}\text { West } \\
\text { Virginin. }\end{array}$ & $\begin{array}{l}\text { Atl other } \\
\text { st:tles.t }\end{array}$ \\
\hline \multicolumn{12}{|l|}{$\begin{array}{l}\text { Establishments classified by number } \\
\text { of personsemployed, not imclur- } \\
\text { ing proprietors and firm mem- } \\
\text { bers: }\end{array}$} \\
\hline 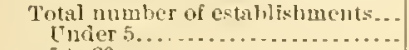 & 231 & 5 & 59 & 5 & 1 & 22 & 20 & 21 & 73 & $\begin{array}{r}11 \\
1\end{array}$ & s \\
\hline . 5 to $20 \ldots \ldots \ldots \ldots \ldots \ldots \ldots \ldots \ldots$ & $\frac{2}{17}$ & & & & & $\ddot{z}$ & & 1 & $\frac{1}{6}$ & & \\
\hline 51 to 100 . & 50 & (n........... & 15 & 1 & & 1 & 5 & $\because 3$ & $1: 2$ & $\frac{2}{1}$ & …… \\
\hline 101 to $250 \ldots \ldots \ldots \ldots \ldots \ldots$ & 98 & 1 & 28 & 3 & 2 & a & 7 & 8 & 26 & 3 & j \\
\hline 251 to $500 \ldots \ldots \ldots \ldots \ldots \ldots$ & 15 & 2 & 10 & 1 & & $\ddot{3}$ & 1 & 7 & 11 & 1 & 3 \\
\hline Over $1,000 \ldots \ldots$ & 5 & $\ddot{2}$ & 1 & (n) & (n) & i & & & 1 & & \\
\hline
\end{tabular}

I Includes establishments distributed as follow: California, 1; Colorado, 1: Georgia, 1; Michigau, 1; Missouri, 1; Virginia, 2: Wiscousil, 1. 

